Revista Herencia Vol. 29 (1), 95-140, 2016

Recibido 20-12-2015 Aprobado 20-01-2016

\title{
DELFINES, LEONES Y TRITONES FUENTES VICTORIANAS DE HIERRO EN PLAZAS Y PARQUES DE COSTA RICA (1868-1880)
}

Sergio Orozco

Abarca

Graduado en Filología Española, de la Universidad de Costa Rica, en el año 1988. Trabajó por más de dos décadas en una empresa de Tecnología, en la creación y comercialización de diccionarios y correctores ortográficos y gramaticales

Como investigador de temas históricos acerca de nuestro país, se ha concentrado en la historia de la fundición artística, proveniente de Europa: farolas, rejas, quioscos, edificios, muelles, etc. pero sobre todo

las fuentes victorianas de hierro colado. Varios de sus artículos se han publicado

en Periódicos Nacionales y también en portales especializados del exterior. sergiorozco@gmail.com

\begin{abstract}
Agradecimientos
Ana Isabel Herrera Sotillo, Ana Patricia Pacheco Ureña, Andy Savage, Carlos Oreamuno Toledo, Eduardo (Edú) Sánchez, Eduardo Vásquez Relyz, Luis Fernando Campos Vargas, Guillermo Brenes Tencio, Hugo Marín Brenes, Jorge Mario Delgado Madrigal, Jorge Arturo Vindas, John Powell, Lucía Juárez, Ronald Castro Fernández, Sergio (Checho) Vargas, The Ironbridge Gorge Museum Trust, The Scottish Ironwork Foundation, ASPM (Association pour la sauvegarde et la promotion du patrimoine métallurgique haut-marnais).
\end{abstract}

A todas las personas y organizaciones, de diversos países, que aportaron fotografías de sus colecciones para el presente artículo.

\section{Introducción}

Durante la época colonial, los labriegos sencillos de Costa Rica solo conocieron el hierro en el pico, la pala, las herraduras y los frenos de caballo. El hierro provenía del exterior; era caro y escaso, y su dominio artesanal le pertenecía a los herreros (Payne, 1986, pp. 49-50). A diferencia de los virreinatos de América (i.e. México, Perú), acá nunca hubo fontanas ni pilas públicas para abasto del agua. Lo más cercano a una fuente eran las pilas de bautismo, los pozos de mampostería y las acequias. El hierro industrial entró en escena con los postes de queroseno importados de Inglaterra, a mediados de la década de 1850, cuando aún faltaban décadas para la aparición de la electricidad. Justamente, un año después, se realizó, en Londres, la Gran Exposición de los Trabajos de la Industria de Todas las Naciones (1851), que vino a ser el pináculo propagandístico de la era victoriana y del siglo imperial británico. El dominio de la producción del hierro (utilitario y suntuario) y la mecanización de la industria textil, convirtieron a Inglaterra en un imperio que comerciaba con muchos países, incluida Costa Rica. Carecíamos de dinero para comprar bienes a Inglaterra, pero ya teníamos el "grano de oro", y gracias a él se facilitó el intercambio comercial. Pudimos, por primera vez en nuestra historia, disfrutar, democráticamente, de los goces de Europa.

En pleno auge económico de la época liberal en Costa Rica, la prosperidad ya se advertía en los parajes y edificios públicos, así como en la construcción de obras de infraestructura (carreteras, muelles, cañerías, red ferroviaria); pero también se apreciaba en las propiedades de personas acaudaladas (cafetaleros, comerciantes, y profesionales).

Todo ello, más la moda y la posibilidad de tener acceso a objetos preciosos europeos, a relativo bajo costo, posibilitó la aparición de fuentes, cráteras, bancas, farolas y otros notables objetos de hierro, en muchos sitios del país. Por ejemplo, algunas municipalidades dispusieron colocar fuentes en sus parques y plazas, 
lo mismo hicieron instituciones religiosas, educativas, hoteles, etc. El hierro sedujo por la facilidad y eficiencia en la construcción de edificios, puentes, mercados, kioscos, etc., así como en la aparición de herramientas, mecanismos para la producción agrícola, y posteriormente, bienes del hogar como las máquinas de coser, estufas, planchas, comales, ollas, etc.

Las fuentes victorianas importadas principalmente del Reino Unido fueron de los primeros objetos artísticos en hierro que conocieron los costarricenses. Hace casi siglo y medio llegaron a Costa Rica, y en este largo período las hemos visto; pero casi no las hemos apreciado. Este artículo y la investigación que realizo desde hace unos tres años, pretende poner las fuentes victorianas en el punto de observación que merecen, para que las generaciones actuales y futuras se ocupen de ellas.

El artículo consta de cinco apartados. Los primeros cuatro corresponden, en orden cronológico, a la instalación de fuentes en San José, Cartago, Heredia y Alajuela. Para cada una de estas provincias, se indicarán aspectos esenciales de las fuentes, como el nombre de los constructores de las pilas, casas fabricantes de las fuentes de hierro, costos, instaladores, restauraciones, etc. El quinto apartado consiste en una pequeña muestra de otras fuentes victorianas en Costa Rica, entre existentes y desaparecidas.

\section{Orígenes}

Juan Rafael Mora Porras (1814-1860), héroe y libertador nacional de Costa Rica, advirtió que el agua es fuente de vida; pero también de muerte. Después de la Campaña Nacional contra los filibusteros (1856-1857), se suscitó una peste de cólera que diezmó a la población costarricense, a causa de una forma inadecuada del tratamiento de los cuerpos de los caídos en la guerra, y a la pésima calidad del agua y su distribución.

Comprendiendo la importancia de dotar a las ciudades de agua potable por medio de cañería subterránea, don Juanito firmó un decreto fundamental, en el año 1857, que dice textualmente:

El Excelentísimo Congreso Constitucional de la República de Costa Rica. Considerando que las facultades que pide el Supremo Gobierno para realizar el proyecto de introducir agua potable a la ciudad de San José, por cañería subterráneas, envuelven gran interés público, no solo porque dicho proyecto es el más benéfico que puede considerarse, sino porque ya urge su objeto para satisfacer muchas necesidades de la economía doméstica y evitar muchos males que por falta de fuentes públicas y privadas se están experimentando, ha venido a decretar y decreta:

Art 1.- Se autoriza al Supremo Gobierno para que disponga de la porción necesaria de las propiedades municipales de la ciudad de San José para procurarse fondos de la manera que lo estime conveniente, a efecto de introducir a la ciudad, la mejor agua potable por cañería subterránea, dictando todas las providencias necesarias al cumplimiento de tan interesante objeto.

Art 2.- Se le autoriza igualmente para que si alguna de las municipalidades de las provincias se halla en el caso de adoptar la misma providencia, puede disponer de los fondos que le pertenecen, con tan laudable fin (Núñez, 2004, p. 53).

Es importante destacar los dos aspectos esenciales del decreto: a) la certeza de que los males que experimenta la población obedecen a la carencia de fuentes públicas y privadas del preciado líquido; y b) que el decreto no fue exclusivo para dotar 
de cañería de agua potable a San José, sino que se autoriza a las municipalidades de las restantes provincias a disponer de los fondos que estimen necesarios, para construir acueductos locales.

Gracias a esta visión de don Juanito fue posible que las municipalidades de las provincias centrales de Costa Rica emprendieran, casi secuencialmente, la construcción de sus acueductos y cañerías.

¿Pero qué tiene que ver todo ello con las fuentes victorianas, objeto de este artículo? Absolutamente todo. Porque en las cuatro provincias centrales -empezando por San José- las municipalidades decidieron coronar las obras de cañería con la instalación de fuentes ornamentales de hierro en las plazas principales (Sanou, 2001, p. 146). Las fuentes no fueron concebidas únicamente como objetos artísticos para embellecer la ciudad. Su función principal era servir de surtidores de agua pura, limpia y gratuita para aquellos habitantes que no podían costear una paja de agua propia en sus casas de habitación. Es decir, las mayorías.

¿Por qué las municipalidades de las provincias centrales siguieron esta práctica? Lo más probable es que al haber tomado la iniciativa San José de culminar su obra con dos magníficas fuentes victorianas, ninguna de las restantes provincias quería quedar en desventaja con respecto a la capital. Además, esta práctica no fue privativa de Costa Rica; en otras regiones de América Latina se colocaron fuentes ornamentales, para celebrar acontecimientos semejantes (1).

Asimismo, estas fuentes y otros ornamentos no pasaron inadvertidos por las clases pudientes, que vieron en ellos la oportunidad de lucir bienes suntuarios de primer nivel. De esta manera que en muchas de las casas de los vecinos principales de las provincias centrales, también se instalaron fuentes ornamentales en hierro, importadas de Europa. En el quinto apartado haremos mención de otras fuentes en Costa Rica, diferentes a las importadas para las cañerías.

\section{[1] Fuentes victorianas de San José (1868).}

\subsection{El hierro y la fuente.}

La hulla grasa es el carbón mineral más abundante en el planeta. Cuando esta se calienta y se somete a un proceso de destilación, se producen gases y sólidos. El sólido resultante es el coque, un tipo de carbón liviano y poroso.

Abraham Darby (1678-1717), un cuáquero y maestro fundidor del hierro y cobre, se estableció en Coalbrookdale, en el condado de Shropshire, Inglaterra, en el año 1708. Allí realizó un notable experimento que sería determinante en el origen de la Revolución Industrial, al utilizar el coque como combustible para fundir el hierro, en lugar del carbón vegetal. De esta manera, ya no sería necesario el carbón vegetal, ni talar bosques enteros, para fundir hierro. A partir de este invento, se pudo producir grandes cantidades de hierro de excelente calidad, a muy bajo costo. Así nació la producción en serie de puentes, rascacielos, edificios prefabricados, postes de luz, y todo tipo de objetos suntuarios (y también modestos) en este material. Nunca habría sido posible alcanzar un nivel de producción de piezas de hierro como alcanzó la humanidad, si solo se hubiera dependido del carbón vegetal.

En 1709, Darby fundó la compañía Coalbrookdale. Después de la muerte de Darby, la compañía se mantuvo en manos de hijos y familiares, por décadas. Francis Darby, hijo de Abraham Darby III, introdujo la línea de fundición de arte en Coalbrookdale.

En el año 1851, la compañía participa en la Gran Exhibición de los Trabajos de la Industria de todas las Naciones, en Londres, apadrinada y promovida por el Príncipe Alberto, esposo de la Reina Victoria. Una de las obras que Coalbrookdale mostró en la Gran Exhibición fue una pequeña fuente ornamental de hierro. La fuente,
(1) En la ciudad de San Miguel de Tucumán, en Argentina, se instalaron, en 1872 , dos fuentes de hierro del mismo fabricante que fundió las fuentes de las ciudades de Cartago y Heredia. Dichas fuentes se instalaron como parte de la cañería de la ciudad; sin embargo, por razones diversas, la cañería no entró en funcionamiento, sino hasta 1874 . 
1.1. Ilustración de la fuente Cupido y el Cisne de Coalbrookdale, tal como se expuso en la Gran Exhibición de Londres, en 1851. Al fondo, los portones Coalbrookdale (hoy en Kensington Gardens, de Londres). Imagen cortesía de Ironbridge Gorge Museum Trust de Coalbrookdale.

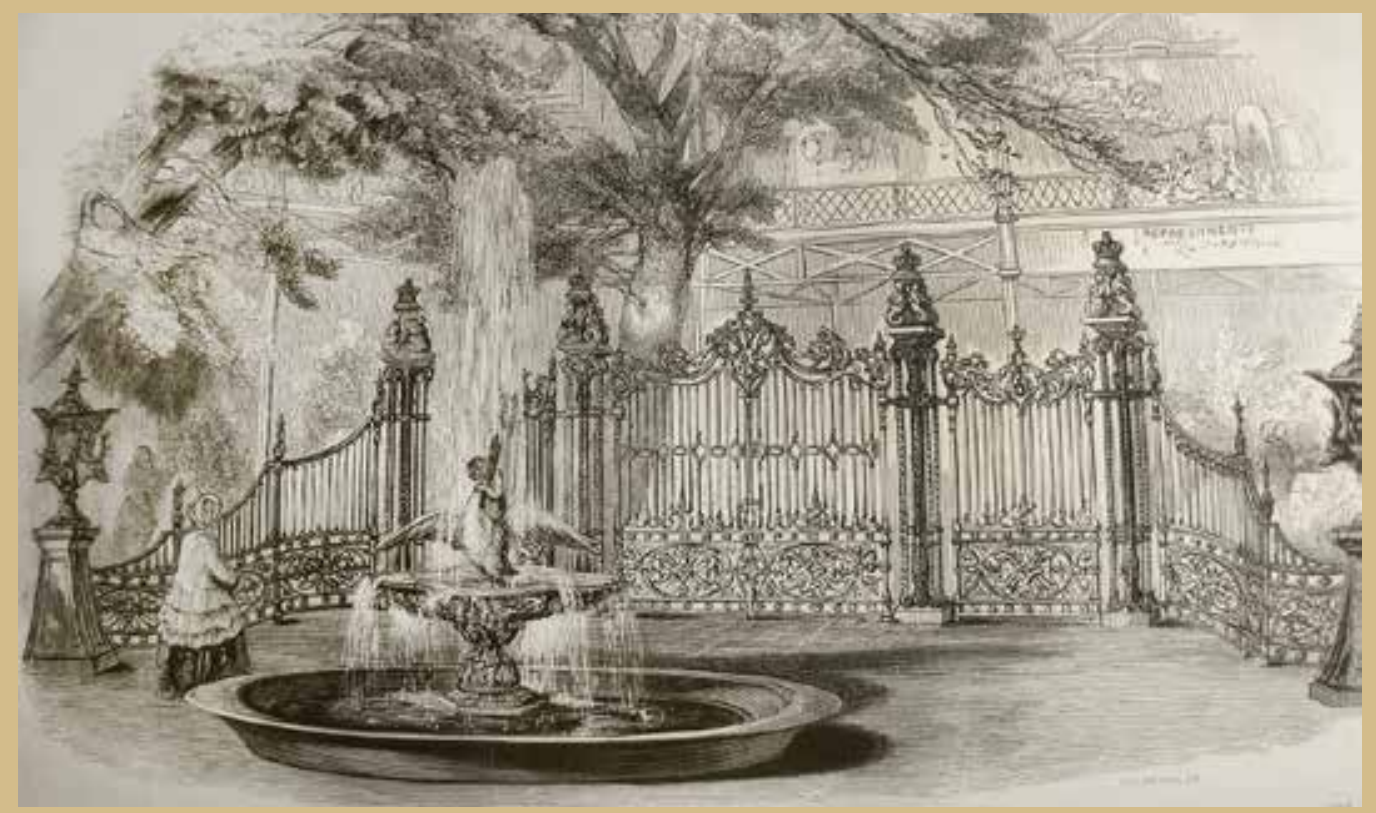

de tonos bronceados, medía dos metros de ancho por dos y medio de alto, y su elemento central lo constituía un grupo formado por Cupido y el Cisne, del cual brotaba un chorro de agua. Este grupo se asentaba sobre una taza decorada con hojas metálicas en forma de nenúfares (The Royal Commission, Londres, 1851, p. 659). La fuente fue diseñada por el escultor John Bell.

Tras la exposición, la fuente fue adquirida por el Ayuntamiento de Wolverhampton y exhibida en su mercado hasta 1880, cuando fue trasladada a West Park. Más tarde se desmontó y se guardó, hasta ser redescubierta por WKV Gale, y finalmente adquirida por The Ironbridge Gorge Museum Trust de Coalbrookdale, en el año 1959, fecha en la que se restauró por primera vez y se colocó en su sitio actual (Powell, 2012, p. 1).

1.2. Fuente

Cupido y el Cisne, de Coalbrookdale, tal como luce en la actualidad en el patio interno del Museo del Hierro, en Coalbrookdale, Shropshire. Foto cortesía del Ironbridge Gorge Museum Trust (2014).

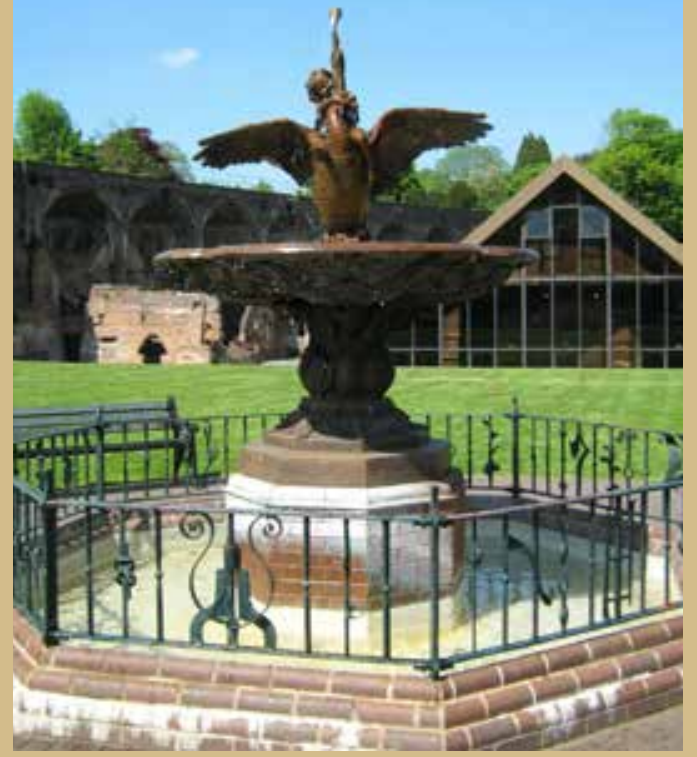

\subsection{La fuente Cupido y el Císne, de San José.}

9000 kilómetros al oeste de Coalbrookdale, se localiza San José, nuestra capital. Estamos a mitad del siglo XIX, en 1858. El gobierno del presidente Juan Rafael Mora Porras, que un año antes había firmado el decreto para dotar de agua potable a las ciudades centrales, suscribió un contrato con los ingenieros Francisco Kurtze y Guillermo Nanne, para instalar una cañería de hierro en la ciudad de San José.

La construcción no progresó por disputa entre las partes, y no es sino hasta 1864, en el primer gobierno de Jesús Jiménez Zamora, cuando inicia el proyecto, esta vez a cargo del ingeniero mexicano y Director General de 
Obras Públicas, Ángel Miguel Velásquez Riggioni (Sanou, 2001, p. 145), quien se basó en el proyecto original elaborado por Kurtze. Se decidió construir tanques y filtros de calicanto en Barrio Aranjuez (contiguo al actual Hospital Calderón Guardia). De estos tanques partiría la tubería subterránea de hierro (traída de Inglaterra), hacia diferentes sectores de San José. Finalmente, la cañería se inauguró el domingo 25 de octubre de 1868, pero no se concluiría hasta el año siguiente (Vargas, 2001, p. 70).

Veinte meses antes de esta inauguración, la Municipalidad de San José había enviado a Europa al ingeniero Velázquez con la misión de adquirir los materiales faltantes de la cañería y algunas piezas de arte, para colocarlas en sitios neurálgicos de la capital.

Velázquez realizaría una compra magnífica. Nada más ni nada menos que tres valiosas obras de la compañía Coalbrookdale, en alguno de sus almacenes de Londres, Bristol o Liverpool.

Esas obras eran: una pequeña pero maravillosa fuente de pared, que relata un pasaje bíblico relativo al profeta Moisés; una exquisita reja perimetral de 400 metros de largo; y para rematar, una réplica de la célebre fuente Cupido y el cisne, con una magnífica pila de hierro.

La fuente de Moisés se colocó en

la parte externa de los tanques de agua de la cañería, construidos en el Barrio Aranjuez, y la reja perimetral se instaló alrededor de la Plaza Principal (hoy Parque Central).

El destino de la fuente Cupido y el Cisne fue el mejor de todos: el centro de la pla$z a$, para que no quedase duda de que aquella fuente representaba la culminación del tendido de cañerías, la obra más importante de la ciudad de San José desde la fundación de la República, y el primer monumento sanitario de Costa Rica (Núñez, 1944 , p. 1, 11). Nuestra capital fue una de las primeras ciudades del continente provistas de cañería subterránea.

La fuente se puso en funcionamiento el día de la inauguración de la cañería. Oficialmente, se dio por inaugurada la obra cuando al abrir la llave, brotó un poderoso chorro de agua del pico del cisne, la que bañó de tonos bronceados el precioso conjunto de hierro y, empezó a llenar, lentamente, la pila (Núñez, 1958, p. 43).

Esta fuente adornó el centro de la Plaza Principal, desde el año 1868, hasta 1944, cuando la Municipalidad de San José decidió realizar cambios al Parque Central, incluyendo la construcción, en su centro, de un kiosco donado por Anastasio Somoza García (Presidente de Nicaragua). Es por este motivo que la Municipalidad
1.3. Composición

fotográfica de las compras hechas por el Ing. Ángel Miguel Velázquez en Inglaterra. Arriba, la fuente Cupido y el Cisne, con su pila de hierro (según datos del Ironbridge Gorge Museum Trust de Coalbrookdale, el precio de catálogo de esta fuente era de $£ 200$ en el año 1860); en medio, la reja perimetral del Parque Central; abajo, la Fuente de Moisés (fuente de pared). Las fotos superiores son de Manuel Gómez Miralles (c. 1922); la foto inferior de Sergio Orozco Abarca (2011). 
1.4. Réplica de la fuente Cupido y el Cisne, en el Parque Central de San José.

Foto cortesía de Jorge Arturo Vindas, tomada de la Revista Panamericana (1912)

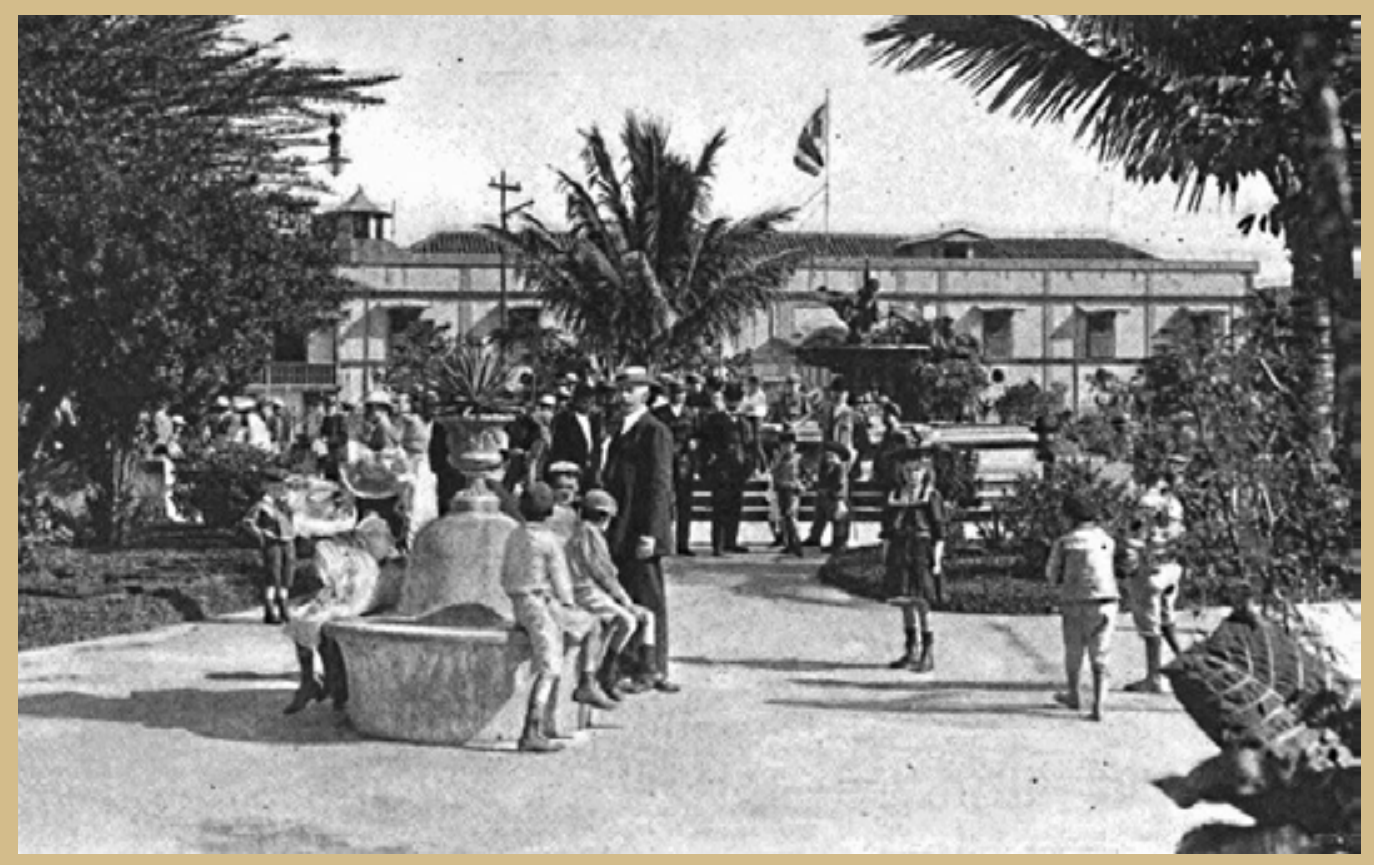

acuerda donar la fuente a la nueva Universidad de Costa Rica, en el barrio González Lahmann, y se ordena su traslado a la plazuela de la Universidad.

A partir de 1952 se inicia el traslado de las unidades académicas de la Universidad a los nuevos terrenos en San Pedro de Montes de Oca. En 1958, el Ing. Santiago Crespo P. Diseñó un proyecto para ubicar la fuente en la futura ciudad universitaria, proyecto que no llegó a ver la luz.

En 1959 se decide quitar la fuente de su sitio, y luego se guarda en unas bodegas municipales. Posteriormente, es trasladada a la Universidad en San Pedro de Montes de Oca; pero queda abandonada y desarmada en un predio, al oeste de los talleres de carpintería - actual Rectoría (Delgado, s.f., p. 11). En 1969, el Ing. Jorge Mario Delgado, Secretario de la Facultad de Agronomía, propone la idea de colocar

1.5. Réplica de la fuente Coalbrookdale, Cupido y el Cisne, tal como luce en la actualidad en la Universidad de Costa Rica. Foto cortesía de Luis Fernando Campos Vargas (2015).

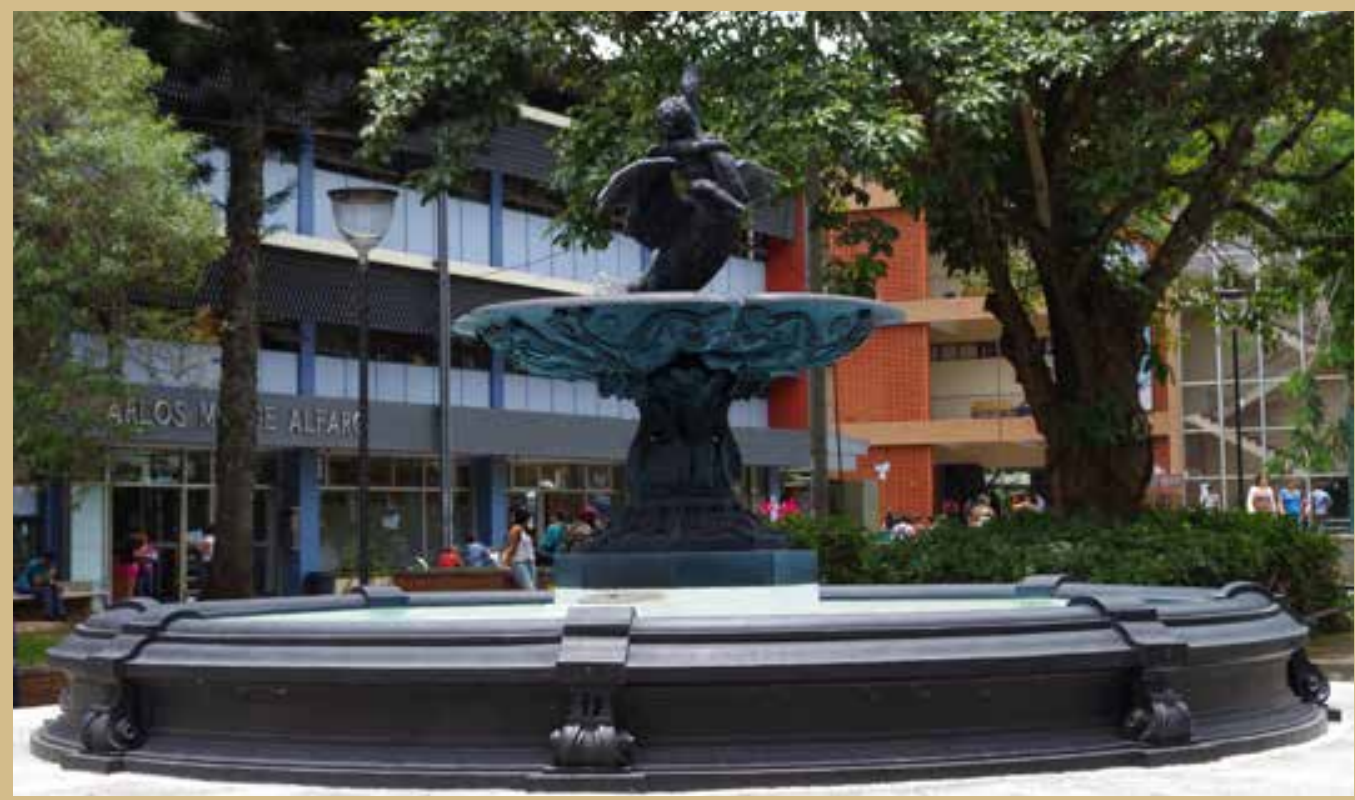


la fuente en el nuevo edificio que se estaba construyendo para la Facultad (2).

En 1971, el Ing. Delgado asume personalmente la responsabilidad de la restauración e instalación de la fuente en el nuevo edificio. Acompañado de un grupo de alumnos, rescatan la fuente del potrero en donde estaba tirada y desarmada. En este proceso realizó una gran gestión el ingeniero Herbert Nanne Michaud, Jefe de Parques de la Municipalidad de San José, y también profesor de la Facultad. La figura del cisne fue restaurada en los talleres de la Municipalidad, y las pequeñas piezas faltantes las funden en la "Fundición Chirino", sin costo alguno para la Universidad (Delgado, s.f., p. 12). En esta labor cooperaron operarios de la unidad de mantenimiento. Finalmente, la fuente es colocada en un patio interno de la nueva facultad, en enero de 1973.

En el año 1974 surge la idea de crear un "Distrito Universitario", en conjunto con la Municipalidad de Montes de Oca. En 1987, el arquitecto Luis Fernando Aronne, junto con el rector Fernando Durán Ayanegui empezaron las gestiones para colocar la fuente en un lugar más visible y asequible. La oposición más férrea provino de los mismos estudiantes, que no querían perder la preciosa corona de la Facultad. Finalmente, en un extenso proceso de negociación, los estudiantes aceptaron el traslado (Delgado, s.f., p. 16).

El 9 septiembre de 1987 la fuente fue declarada Patrimonio Histórico y Artístico, por el Presidente de la República y el Ministerio de Cultura.

En febrero de 1989, la entonces diputada Rosemary Karpinsky ofrece destinar dineros reservados de partidas específicas, para llevar a cabo obras en el Cantón de Montes de Oca. Con el apoyo del rector Dr. Luis Garita Bonilla, el Consejo Universitario acuerda la reactivación del proyecto para conformar el "Distrito Universitario". Dicho proyecto contemplaba construir un bulevar, así como un monumento a
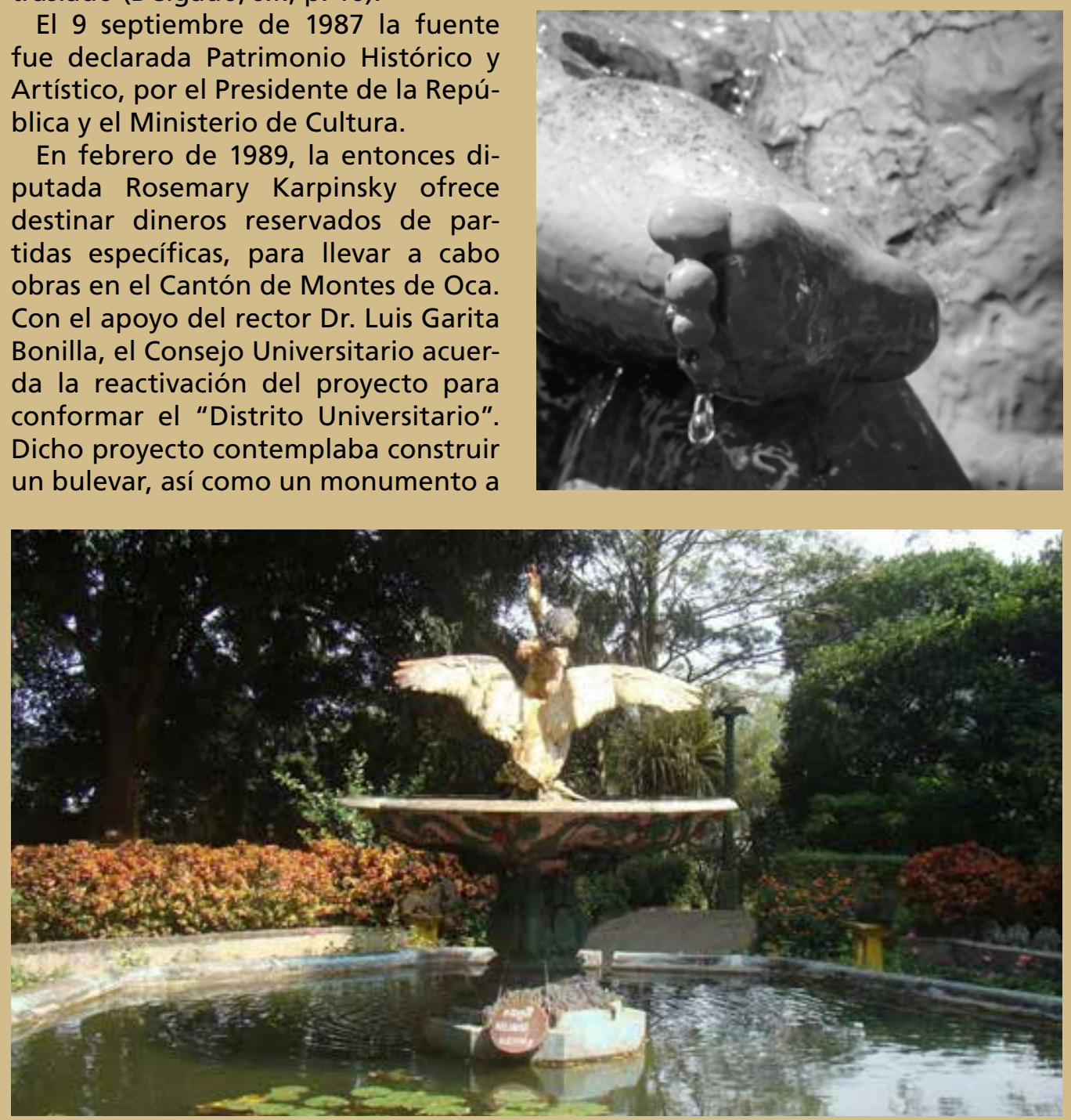

(2) El Ing. Jorge Mario Delgado Madrigal (1926-2015), no solo fue determinante en el rescate de la fuente; fue, además, la primera persona en realizar un intento por documentar su historia. Lo plasmó en un documento inédito de unas 20 páginas escritas a máquina, llamado "La fuente peregrina", cuya información ha sido muy valiosa para este artículo.

1.6. Detalle de la fuente Cupido y el Cisne, en la Universidad de Costa Rica. Foto: Sergio Orozco Abarca (2011)

1.7. Réplica de la fuente Cupido y el Cisne, en el parque del Palacio Real de Kandy, Sri Lanka. Foto cortesía de Nelson Mangalama (htttp:// discover-srilanka. blogspot.com, 2013). 

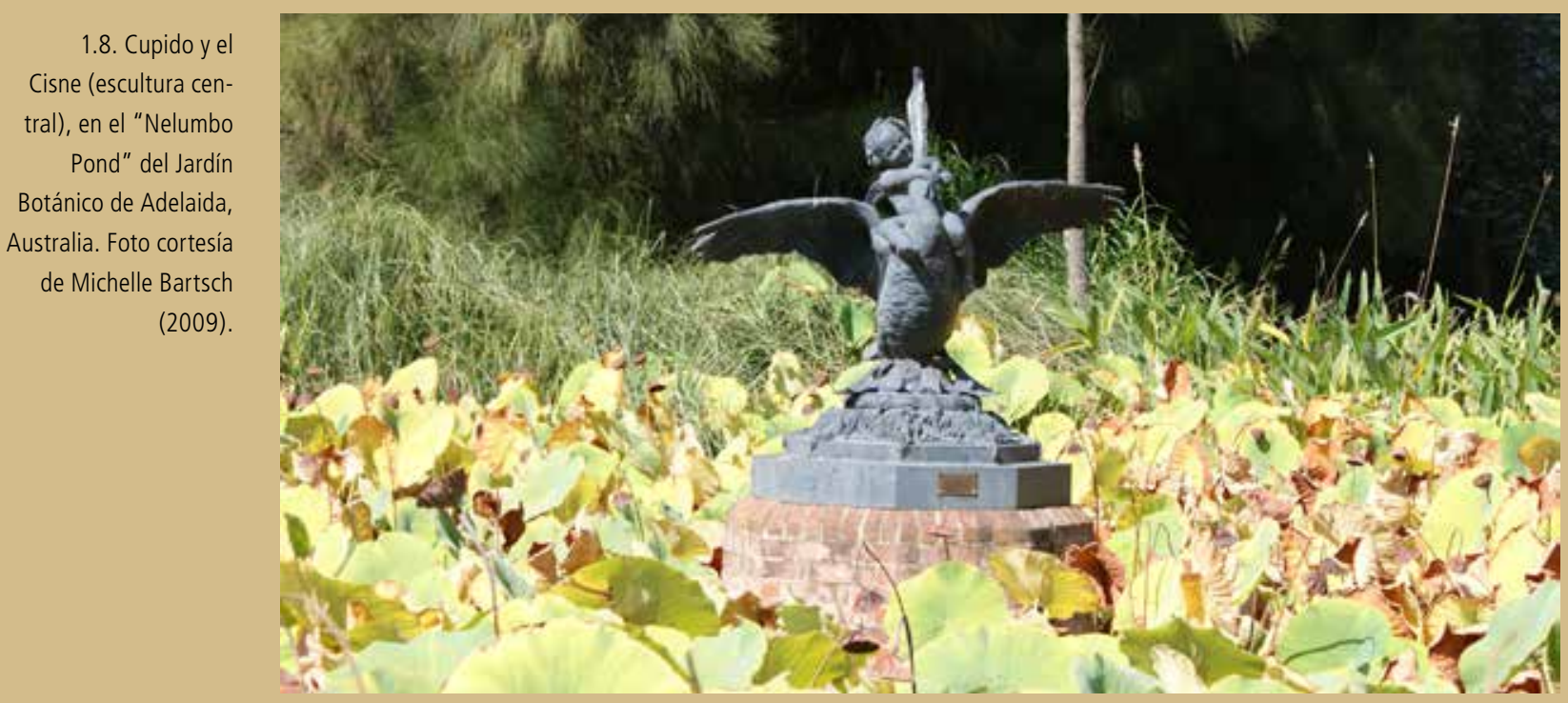

la bandera y un monumento a la fuente; este Monumento consistiría en una gran plaza con la fuente en el centro, sin tocar ninguno de los árboles; esto permitiría el desplazamiento del "pretil" más hacia afuera (Actas del Consejo Universitario de la Universidad de Costa Rica. Sesión No.3544, ordinaria, 28 de febrero de 1989. Art $4^{\circ}$.). La propuesta era bautizar todo el emplazamiento con el nombre de Plaza Santo Tomás, "en recuerdo de la Universidad ancestro de la Universidad de Costa Rica" (Actas del Consejo Universitario de la Universidad de Costa Rica. Sesión No.3816, ordinaria, 18 de febrero de 1992. Art 3, en Delgado s.f., p. 17).

En febrero 1991, se inicia la segunda restauración de la fuente, a cargo del escultor Max Ulloa Royo, y coordinada por ICOMOS Costa Rica (Vecinos, 1991). A finales de 1991, se instala la fuente y el 27 de febrero de 1992 se inaugura la Plaza, con la fuente en su centro.

En el año 2012, la fuente se encontraba en franco deterioro. Fue así como la Oficina de Servicios Generales de la UCR, con el apoyo de la Vicerrectoría de Acción Social, dispuso someterla a una nueva restauración. El proyecto, coordinado por el arquitecto Javier Campos y ejecutado por la restauradora Ana María Moraleda, ha puesto en valor esta obra tan emblemática de la historia de Costa Rica.

Durante años, las autoridades del Ironbridge Gorge Museum Trust, creyeron que su fuente era única; sin embargo, después del año 2000, se conoció la existencia de seis ejemplos sobrevivientes, incluyendo una en el Jardín Botánico de Adelaida, Australia; una en el parque del Palacio Real de Kandy, Sri Lanka; y otra en Estados Unidos. Finalmente, en 2013, las autoridades del museo incluyeron, en sus registros, la fuente Cupido y el Cisne de Costa Rica.

\subsection{La fuente de pared de los tanques de Aranjuez (Fuente de Moísés).}

(3) El original en ingles dice: "He opened the rock, and the waters gushed out; they ran in the dry places like a river. Psalm CV-41".

En el extremo oeste de los tanques de agua, en Barrio Aranjuez, se colocó la fuente de pared, adquirida en Inglaterra por Ángel Miguel Velázquez. Los cinco tanques de agua de la cañería fueron declarados Patrimonio Histórico-Arquitectónico de Costa Rica, el 18 de febrero del año 2004, mediante decreto $N^{\circ} 31789-C$. Curiosamente, el decreto no hace mención alguna de la valiosa fuente de hierro de pared. Por formar parte del conjunto, se sobreentiende que la declaratoria de patrimonio alcanza también a la fuente. 
La fuente incluye una historia bíblica que relata el milagro del agua, y por el cual se reafirma la importancia del líquido vital para los seres vivos. A la izquierda, se muestra a Moisés golpeando la roca - de la cual brota el preciado líquido-, y el verso bíblico "Abrió la roca y las aguas brotaron, y por la tierra seca corrían como ríos, Salmo 105: 41" (Biblia Latinoamericana) (3).

A la derecha vemos una mujer con una escudilla en su mano, dando de beber el agua — salida de la roca- a un niño desnudo y sediento. El milagro adquiere sentido cuando el niño sacia la sed, bajo la mirada tutelar de los ángeles. El centro de la fuente la constituye el surtidor de agua, en cuyo borde destaca el nombre y procedencia de los escultores de la obra (Wills Brothers Sculptors, London). Al fondo del surtidor se aprecia una gruesa concha de mármol, de la cual brota el chorro de agua que provee la fuente.

En el año 2014, el Centro de Investigación y Conservación del Patrimonio Cultural del Ministerio de Cultura, intervino para rescatar la fuente original que se encontraba en muy malas condiciones y expuesta al vandalismo. Se realizó una restauración de toda la fuente, y se encargó la fundición de una réplica. La réplica se colocó en el sitio original, es decir la pared oeste de los tanques de agua, y la original se colocó en una placa especial a la entrada del Hospital Calderón Guardia. La obra estuvo a cargo de la restauradora Ana Moraleda.

En la calle Ellison, en Hebburn (nordeste de Inglaterra) había una fuente idéntica a la nuestra, en perfecto estado. Tristemente, en 2005, los ladrones entraron al edificio donde se encontraba y fueron capaces de desprenderla de la pared, para robarla. Transcurridos más de diez años desde su desaparición, se ignora su destino, para desconsuelo de los habitantes de Hebburn, quienes han visto perdido uno de sus tesoros. Se sospecha que

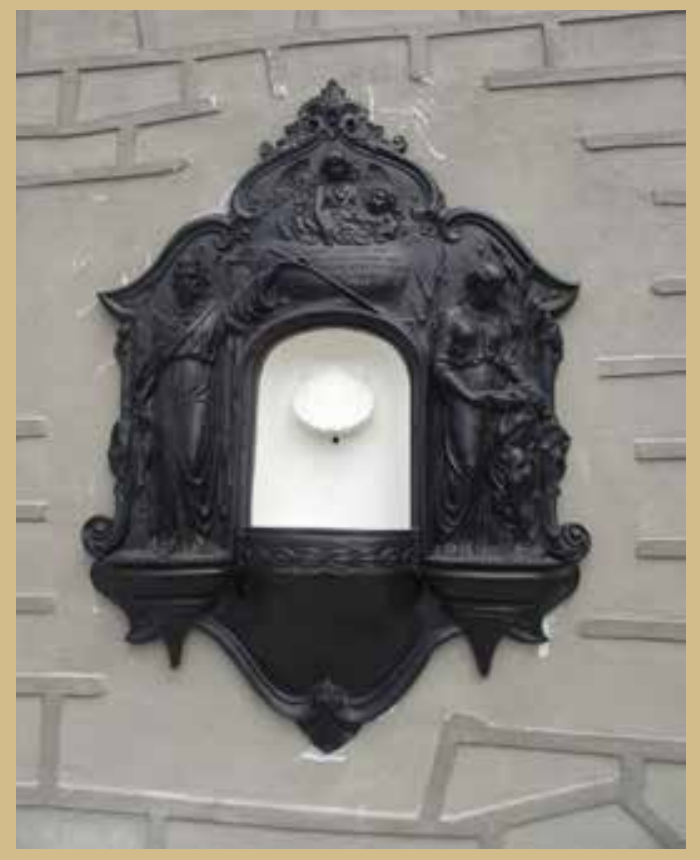

1.9. Réplica de la Fuente de Pared diseñada por los escultores británicos Willam y Thomas Wills, y fundida por Coalbrookdale \& Co., tal como luce en la actualidad, en los antiguos tanques de agua, de San José. La fuente original se colocó a la entrada del Hospital Calderón Guardia, en 2014. Foto: Sergio Orozco Abarca (2015).

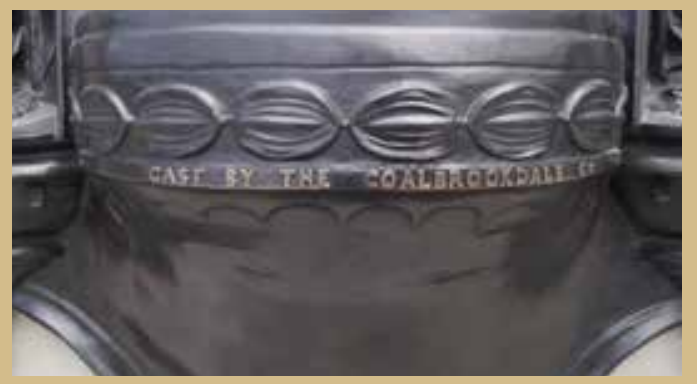

1.10. Detalle del surtidor de la fuente de pared, en la que se aprecia la marca del fabricante: Coalbrookdale \& Co. Foto: Sergio Orozco Abarca (2015).

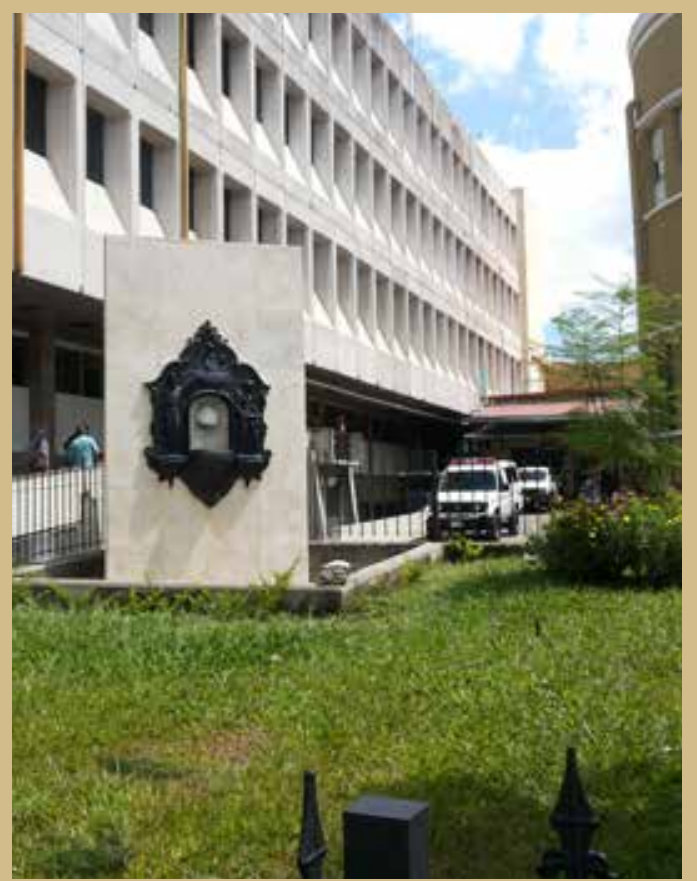

1.11. Fuente de Moisés, totalmente restaurada, como luce actualmente a la entrada del Hospital Calderón Guardia. Foto: Sergio Orozco Abarca (2015). 
1.12. Fuente de Moisés, antes de ser robada del astillero Hawthorne Leslie, de Hebburn, en el año 2005. Foto cortesía de Jim Scott (www. jimscott.co.uk)

1.13. El atroz boquete dejado por los ladrones, después del robo de la fabulosa fuente de Hebburn, en el año 2005. Foto cortesía de Purcell Architects, Reino Unido (http://www. purcelluk.com/).

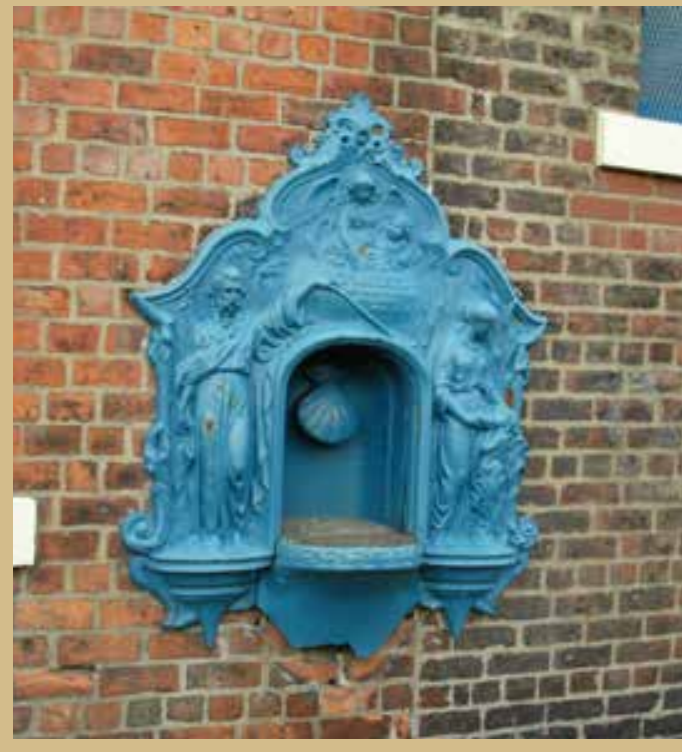

fue fundida, o vendida a un coleccionista, en el mercado negro.

De no haber intervenido las autoridades del Ministerio de Cultura, la fuente de Moisés de nuestro país pudo correr con una suerte similar a la fuente de Hebburn.

\section{[2] Fuentes victorianas de Cartago (1873).}

Que en Cartago hubo varias fuentes de hierro, a finales del siglo XIX lo confirman connotados autores y testigos de excepción. Francisco Montero Barrantes, en su obra Geografía de Costa Rica, del año 1892, señala que en Cartago "hay una plaza principal y varias plazuelas, todas con fuentes de hierro" (Montero, 1892, p. 189). Mario Sancho Jiménez, narra que:

Cartago tenía tres fontanas modestas como todo lo suyo, pero que no carecían de encanto... aquellos tres humildes surtidores de agua, el del Parque Central, el de La Soledad, y el de San Nicolás, sobre todo este, con sus tres delfines boca abajo, agrupados en guisa tan graciosa, todavía conmueven nuestras añoranzas con un hálito de belleza (Sancho, 1933, p. 100).

Asimismo, en los Apuntamientos geográficos, estadísticos e históricos compilados por Joaquín Bernardo Calvo, en 1887, se indica que Cartago "cuenta con una cañería de hierro, que surte, a su vez, a varias fuentes que adornan las plazas públicas" (Calvo, 1887, p. 184).

Al igual que ocurrió en San José y en las otras provincias centrales de Costa Rica, las fuentes de Cartago están estrechamente vinculadas a la construcción de la primera cañería subterránea. La Municipalidad creyó conveniente que ellas fueran el broche de oro de la magna obra, que sirvieran de adorno a las plazas $y$, ante todo, que surtieran de agua a las mayorías.

El 11 de diciembre de 1869, la Gobernación de Cartago publicó un aviso en La Gaceta, en el cual señala que la Municipalidad decidió construir "pilas o fuentes" en sus plazas: la Plaza Principal, la de La Soledad y la de San Nicolás Tolentino (La Gaceta, 1869, p. 5) e insta a los contratistas interesados a dirigirse a la gobernación, en un plazo de quince días, para retirar la información.

En el mes de abril de 1870, el Presidente de la República, don Jesús Jiménez Zamora, envía un memorándum al administrador del Banco Nacional informándole que el Gobierno ha eximido a la Municipalidad de Cartago de los cargos de los derechos de aduana, "para la introducción de los útiles de cañería para la ciudad" (Archivo Nacional de Costa Rica, Hacienda 20212, Fol. 85.). Este memorándum y el acuerdo 
municipal anterior evidencian que la Municipalidad de Cartago siguió los pasos a la Municipalidad de San José en la construcción de su cañería y que, aunque la cañería de Cartago se inicia en el año 1870, la gestación del proyecto ocurre un año antes.

En julio de 1872, la corporación municipal firma un contrato con los señores José Quirze (ingeniero) y Luis Müller (mecánico), vecinos de San José, para la construcción de los tanques, pilas y la obra completa de la cañería de esta ciudad. En el pliego de detalles del contrato se señala que "las pilas de las plazas quedarán concluidas con arreglo al plano, con excepción de las fuentes de hierro, que serán colocadas de cuenta de la contrata y costeadas estas por la Municipalidad" (Actas Municipales de Cartago, 1872-1873, Exp. 17642, Lib. 00, fol. 52. Ortografía actualizada).

Previamente, la Corporación había firmado un contrato con el Sr. Juan Orlich Sfrarozé, artesano cantero natural de Croacia (de La Goublaye, 2010, p. 17), para la construcción de la pila de la plaza principal, en la cual se colocaría la fuente de dicha plaza. No es difícil imaginar que fuera el mismo Sr. Orlich el constructor de las pilas y gradas, para las fuentes en las plazas menores de San Nicolás Tolentino y La Soledad.

Las tres fuentes fueron adquiridas e instaladas en el proceso de construcción de la cañería, que concluiría a finales de 1873. Hay dos acontecimientos de ese año, que dejaron profunda huella en el progreso de Cartago: la cañería, concluida el 31 de octubre; y la llegada del ferrocarril a la ciudad, el 16 de diciembre.

\subsection{La fuente en la Plaza Principal de Cartago (Fuente de los Leones).}

La Plaza Mayor de Cartago constituye no solo el eje central de la ciudad -tal como fue establecido en las Ordenanzas Reales-, sino la matriz misma donde se alojó el embrión de la nacionalidad costarricense. Durante la época de la Colonia y también en una parte de la Era Republicana fue una especie de Ítaca: el punto de partida pero también de llegada de toda travesía. Como bien lo afirma, el escritor Eduardo Castillo en su ensayo "Plaza Mayor de Cartago... ¿por qué?, ¿para qué?, ¿de quién?":

Centro de la ciudad principal en la época de la Colonia, esta plaza fue el punto de partida de todos los que quisieran ir a cualquier lugar de la entonces provincia de Nueva Cartago y Costa Rica. Desde allí salía el camino de mulas a Panamá, el camino a Matina en el Atlántico, la ruta a Caldera en el Pacífico y a Nicaragua. Podía decirse en esa época, parafraseando el dicho popular, que todos los caminos llevaban a Cartago y específicamente a su Plaza Central, o Plaza Mayor (Castillo, 1977).

Por si fuera poco, sobre su empolvado suelo se celebraron actos circunspectos como las juras de los reyes, pero también actos atroces como las ejecuciones de indígenas rebeldes contra la corona. Fue la Plaza Mayor el escenario perfecto para los festejos religiosos y para las corridas de toros, para la compra y el trueque de
2.1. Aviso de la Gobernación de Cartago, en La Gaceta del 11 de diciembre de 1869. 
2.2. Fuente de Leones de Cartago, fabricada en Inglaterra por Britannia Foundry (de Andrew Handyside \& Co.). Foto de autor desconocido, tomada entre 1873-1891, propiedad del Archivo Nacional de Costa Rica. Modificación: Sergio Orozco Abarca

(2015).

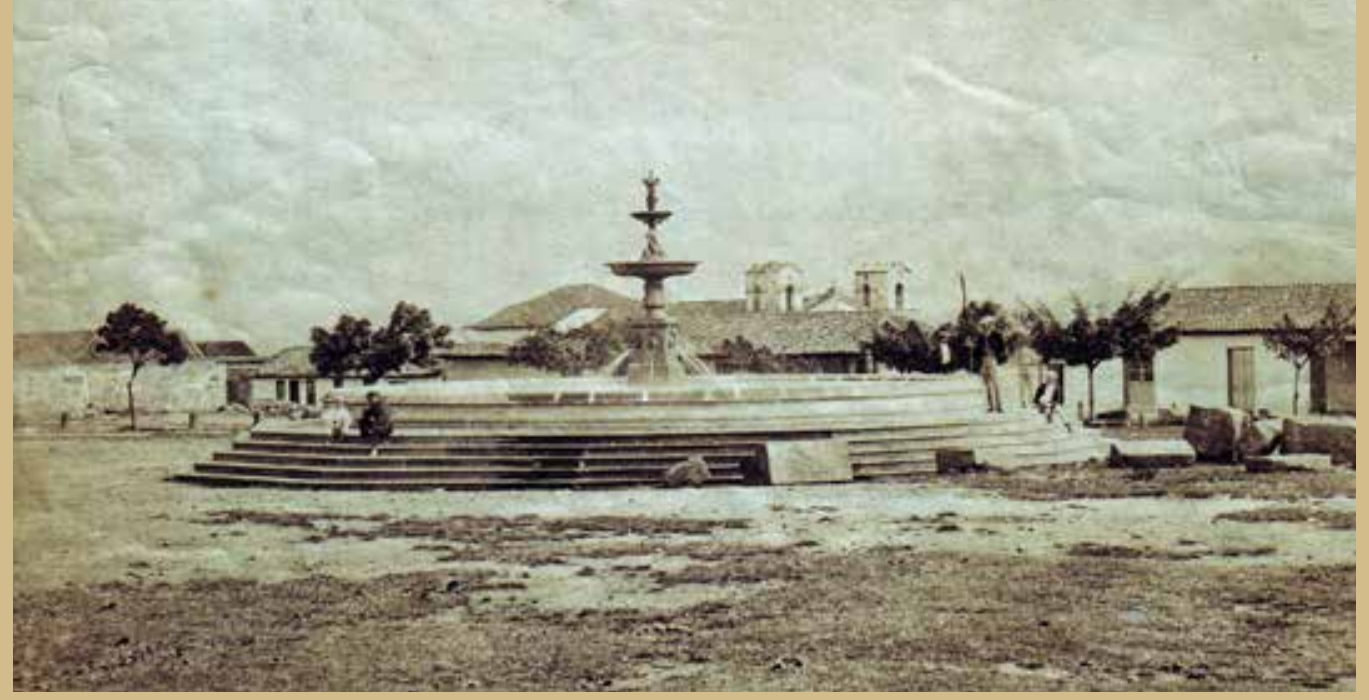

toda clase de mercancías los días de mercado y, en uno de sus vértices, se efectuó el acto más trascendental de la historia patria: la declaración de la Independencia de Costa Rica del Reino de España, el 29 de octubre de 1821.

Como hemos mencionado, las fuentes llegaron a Cartago para conmemorar la instalación de la primera cañería y para surtir de agua limpia y gratuita a la ciudad. La Municipalidad, mediante contrato, dispuso que la pila de la Plaza Principal fuera grande y llamativa, digna de la fuente de hierro que albergaría y del tipo de acontecimiento que esta celebraría. Por ello habían firmado el contrato con don Juan Orlich, para que fabricara la pila de la plaza principal (y seguramente también las pilas de las plazas menores de las iglesias).

Recordemos que en julio de 1872, la Corporación Municipal firmó un contrato con los señores José Quirze y Luis Müller, para la construcción de los tanques, pilas y colocación de la cañería. Asimismo, el contrato establecía que estos ingenieros serían los responsables de instalar las fuentes en las pilas. El costo de las fuentes, sin embargo, correría por cuenta de la Municipalidad.

Para el mes de mayo de 1873 , los ingenieros se percatan de un problema importante. Ya la pila de la Plaza Principal está concluida, según el plano original con que trabajó el señor Juan Orlich. Sin embargo, basados en los datos de las dimensiones de la fuente, los ingenieros advierten que el tamaño de la pila no es suficiente para "abrazar la caída del agua" (Actas Municipales de Cartago, 1872-1873, Exp. 17642, Lib. 00, fol. 206.), es decir que la altura de la fuente y el empuje del chorro, combinados con el efecto de la fuerza del viento provocarían que una cantidad de agua, cayera, sistemáticamente, fuera de la pila provocando que la plaza siempre estuviera mojada, con el agravante para el mercado, y para la salubridad y el ornato públicos. Así lo hacen saber ellos a la Corporación, la cual crea una comisión para analizar el costo de ampliación de las dimensiones de la pila. Finalmente, se aprueba un nuevo contrato específico para la ampliación de la pila.

La fotografía 2.2 fue tomada mirando hacia el sureste. Las torres que se aprecian al fondo pertenecen al convento de San Francisco (posteriormente destruido por el terremoto de Santa Mónica). Al fondo a la izquierda, el extremo suroeste de la cuadra del templo parroquial de Santiago Apóstol, en ruinas desde el terremoto de San Antolín (1841).

Exceptuando el pedestal, esta fuente guardaba gran similitud con las fuentes de San Nicolás y de La Soledad. Sin embargo, en su conjunto, esta superaba los 4 
metros de altura; mientras que las otras dos fuentes pequeñas medían 2,95 metros. Asimismo, la Fuente Principal fue planeada como el elemento decorativo que coronaría la instalación de la cañería. Esta fuente se componía de un bellísimo pedestal, sobre el que se apoyaba una taza grande y poco profunda decorada con hojas de acanto. Sobre la taza, se elevaba una peana con tres delfines entrelazados, con sus bocas hacia abajo; las colas servían de soporte a una taza menor -igualmente decorada con hojas de acanto- coronada esta por otra peana y dos amorcillos (putti) desnudos abrazados a un cañón vertical, del que brotaba el chorro de agua. El sofisticado pedestal, en forma hexagonal, no solo le confería elegancia al conjunto, sino mayor altura. En su base, sobresalían, incrustadas en sendos óvalos, seis cabezas de leones, de cuyas fauces brotaban chorros de agua hacia la pila.

Solo con un propósito meramente utilitario, y exclusivamente para el propósito de esta investigación, en adelante nos referiremos a ella como la Fuente de Leones.

La pila, originalmente fabricada por Juan Orlich, y luego reformada y ampliada por el mecánico Luis Müller (don José Quirze falleció antes de dicha ampliación, y lamentablemente no pudo ver la fuente concluida), tenía las siguientes medidas: un diámetro de 14 varas (12 metros), la pared contaba media vara de espesor $(42 \mathrm{~cm})$ y de altura con el remate 2 pies $(61 \mathrm{~cm}$ ) (Actas Municipales de Cartago, 1872-1873, Exp. 17642, Lib. 00, fol. 245).

El contrato de ampliación de la pila obligaba a Müller a entregar la obra el último día de octubre de 1873. A inicios de septiembre, la Corporación pasó un comunicado a la firma Clavera y Cía. —especializada en servicios de aduana-informándoles que se había girado una orden de pago por las sumas adeudadas y pidiéndoles que enviaran lo más pronto posible "las cajas de materiales pertenecientes a las fuentes de las pilas de esta ciudad" (Actas Municipales de Cartago, 1872-1873, Exp. 17642, Lib. 00, fol. 253.). La corporación comisiona a don Buenaventura Espinach Bonilla, para recibir los bultos con las fuentes y otros materiales de cañería. Este acuerdo clarifica que a inicios de septiembre, las fuentes estaban aún en la aduana de Puntarenas.

Con fecha 15 de octubre, la corporación aprueba pagar un saldo a don Luis Müller por los trabajos de la pila de la plaza y a don Guillermo Dent por fletes de materiales de cañería.

Finalmente, el día 25 de noviembre se contrata a don José Valverde la pintura de la fuente y el zócalo de la pila principal, por la suma de $\$ 68$ pesos. Los datos anteriores indican que, con altísima probabilidad, las fuentes de Cartago debieron ser instaladas y puestas en funcionamiento en la fecha estipulada en el contrato de ampliación, es decir, el viernes 31 de octubre de 1873.

\subsection{La fuente en la plazoleta de la Iglesia de La Soledad.}

La Iglesia de La Soledad se localizaba en el sitio donde actualmente funcionan los Tribunales de Justicia de Cartago (Avenida 2, Calle 5). El culto a la Virgen de La Soledad en dicho sitio, data desde el siglo XVII. La iglesia, de estilo neoclásico, fue reconstruida después del terremoto de San Antolín (el 2 de septiembre de 1841). Según Brenes (2012):

En la esquina noroeste del cuadrante donde se encontraba este macizo templo se hallaba una plazoleta que tenía cincuenta varas de ancho por setenta y cinco de fondo... En el centro de la Plaza Menor de la iglesia de La Soledad se instaló una bellísima fuente ornamental de hierro fundido con tres depósitos. La iglesia parroquial de Nuestra Señora de La Soledad fue totalmente derruida por el terremoto de 
2.3. Iglesia de La Soledad con plaza y fuente. Encerrada en un círculo, se aprecia la cúspide de la fuente. Foto: Otto Siemon (c. 1873). Modificación: Sergio Orozco Abarca (2012).

(4) Laferriere, J (1877). De Paris a Guatemala. Notes de Voyages au CentreAmérique 1866-1875.

Paris Garnier frères libraires-éditeurs.

2.4. Iglesia de La Soledad con plaza y fuente. Grabado de Eugene Guillon (c. 1874). Modificación: Sergio Orozco Abarca (2012)

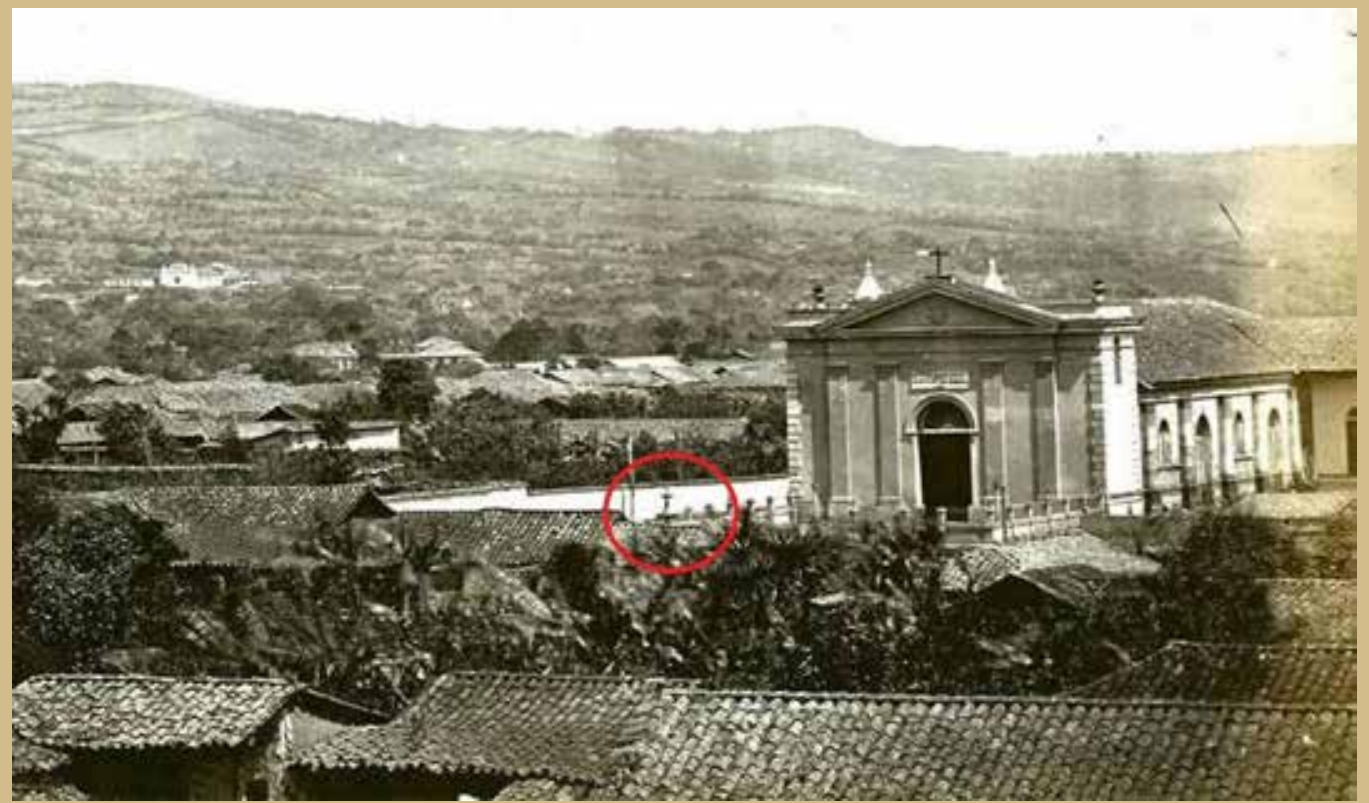

Santa Mónica del 4 de mayo de 1910. No fue reconstruida nunca más; en su lugar quedó la que se llamó la "Plaza de La Soledad", hasta que el espacio fue ocupado para levantar el edificio de los Tribunales de Justicia de la ciudad de Cartago. (Brenes, 2012, p. 228)

Tristemente, hay muy pocas imágenes de la Iglesia de La Soledad, su plaza y su fuente. Al igual que las otras fuentes, esta fue instalada en el año 1873. Una imagen captada por el fotógrafo alemán Otto Siemon en ese año (probablemente tomada desde una de las torres del Convento de San Francisco), nos permite apreciar la fachada de la Iglesia, y su plaza menor. En el centro de la plaza, apenas sobresaliendo entre los techos de teja de las casas vecinas, se aprecia la cúspide de la fuente (2.3).

Como parte de un periplo por Centroamérica, el viajero francés Joseph Laferrière, pasó por Costa Rica, entre 1873 y 1874. Sus viajes quedaron plasmados en una obra (4) llena de excelsas ilustraciones del grabador Eugène Antoine Guillon. En uno de dichos grabados (Cáceres, 1881, p. 15) se aprecia la plaza menor con la fuente (imagen2.4).

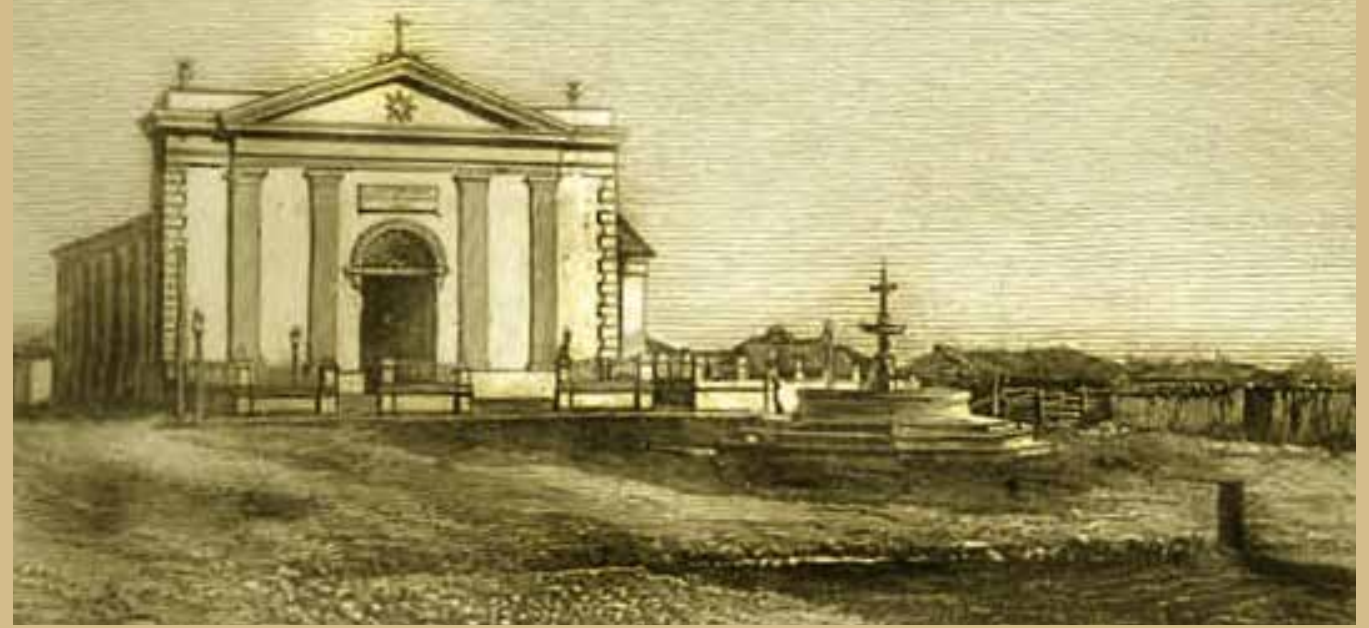


En el grabado observamos que se trata de una fuente de tres depósitos de agua con su respectiva pila, bordeada de una escalinata octogonal de tres niveles. A pesar de la calidad del grabado, no nos permite distinguir, en detalle, los cuerpos de metal, para poder compararlos con la fuente de San Nicolás Tolentino (Fuente de Delfines). Sin embargo, la imagen hace pensar que se trata de un modelo muy similar (o quizás idéntico) a dicha fuente.

\subsection{La fuente en la plazoleta de San Nicolás To- lentino.}

La iglesia de San Nicolás Tolentino estaba ubicada donde hoy se encuentra la Catedral de Cartago (avenida 1, calle 6). El primer templo fue una ermita de barro y madera, con techo de paja, construido en 1647 por los Padres Agustinos, a cuya orden perteneció San Nicolás Tolentino (1245-1305). Como ocurrió con la mayoría de templos y edificios del Cartago antiguo, este fue derribado, sistemáticamente, por terremotos.

Después del terremoto de San Antolín en el año 1841, el Presidente Braulio Carrillo ordenó reedificar, únicamente, el templo Parroquial y el de La Soledad. Sin embargo los sacerdotes jesuitas, que en año 1876 habían tomado posesión del lugar, edificaron en 1879 un nuevo templo, cuyo diseño y planos los realizó el padre Santiago Páramo Ortiz (1841-1915). Originalmente, la iglesia no tenía plaza, motivo por el cual los vecinos y devotos ayudaron a comprar el terreno del frente, para que la iglesia tuviera su plaza, como la tenían los otros templos de Cartago (Mata, 1999, p. 376).

Afortunadamente, de ella sí disponemos de registros fotográficos. El primero que conocemos data de casi un par de décadas después de instalada en la plaza menor. Fue el fotógrafo Henry G. Morgan, en su libro Views of Costa Rica, de 1892, donde nos muestra, por primera vez, la Fuente de Delfines (5), en la pequeña plaza menor de San Nicolás Tolentino (imagen 2.5).

Si comparamos el grabado de Eugene Guillon con esta imagen, advertimos que las fuentes, en ambas imágenes, son muy similares o quizás idénticas. Puesto que

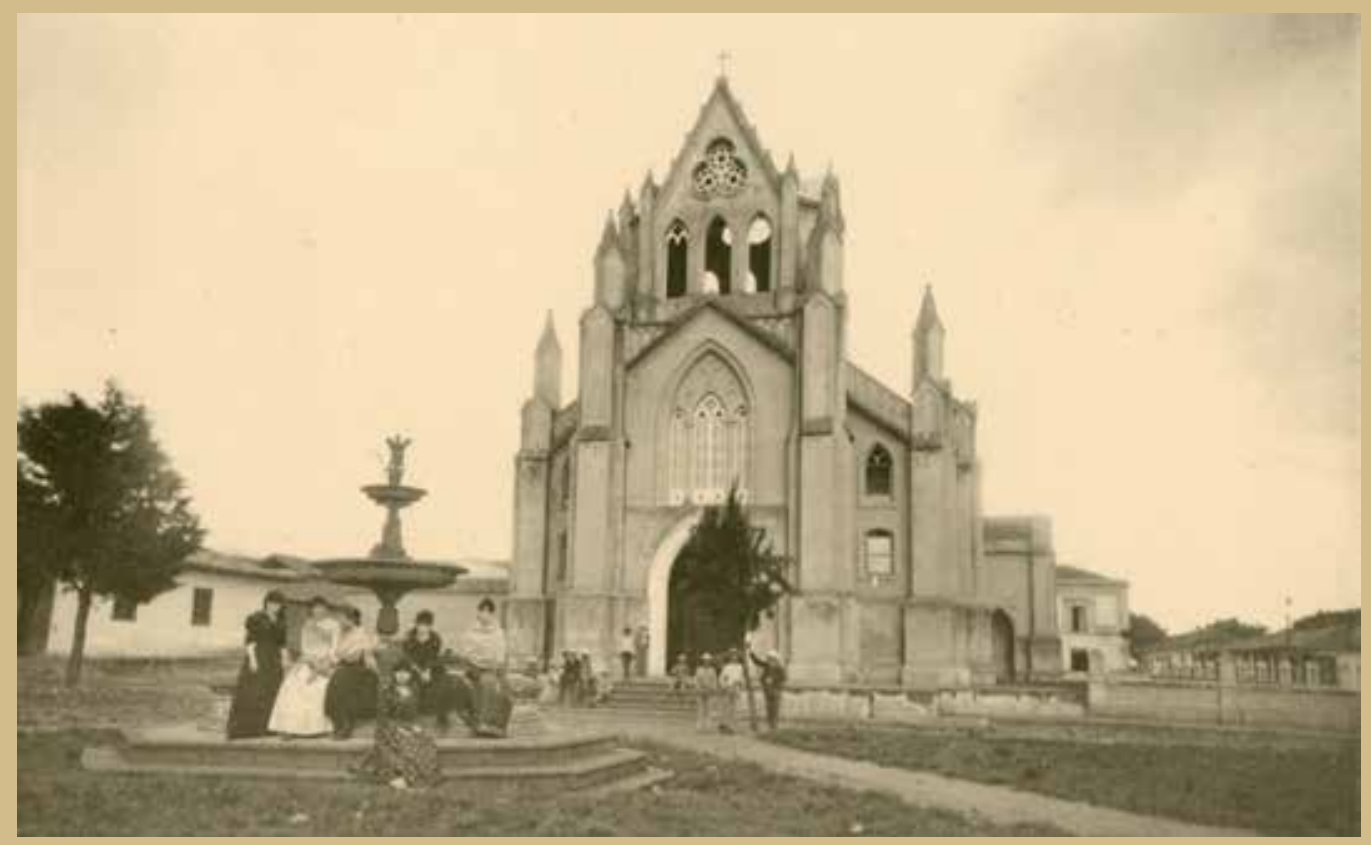

(6) El nombre

Fuente de Delfines se utiliza en este artículo e investigación por dos razones. La primera, de orden práctico: para diferenciarla aquí de otras "hermanas", "primas" y "parientes" en nuestro país,

carentes de nombre también. La segunda razón es académica: en un libro publicado por la casa fabricante de la fuente (Matheson, 1877), se indica que el ornamento central de ésta lo constituyen unos delfines entrelazados, y se denomina a la fuente-ejemplo, como Fuente de Delfines (Dolphins Fountain).

2.5. Iglesia de San Nicolás Tolentino, con su plaza y la Fuente de los Delfines Foto: Henry G. Morgan (c. 1892). 
2.6. Iglesia de San Nicolás Tolentino (con plaza y fuente) destruida por el terremoto de Cartago en 1910. Al fondo, a la izquierda, la fachada del Colegio de San Luis Gonzaga.

Foto: Harrison

Nathaniel Rudd, cortesía de Fraser Pirie Robson. Modificación: Sergio Orozco Abarca (2015)

(6) Los días jueves, la plaza funcionaba como mercado, en el que se comercializaba todo género de mercancías. Para información acerca de esta actividad, léase el artículo de Guillermo Brenes Tencio: "Un día de Mercado en la Cartago Colonial", http://www. micartago.com/index. php?news $=3953$.

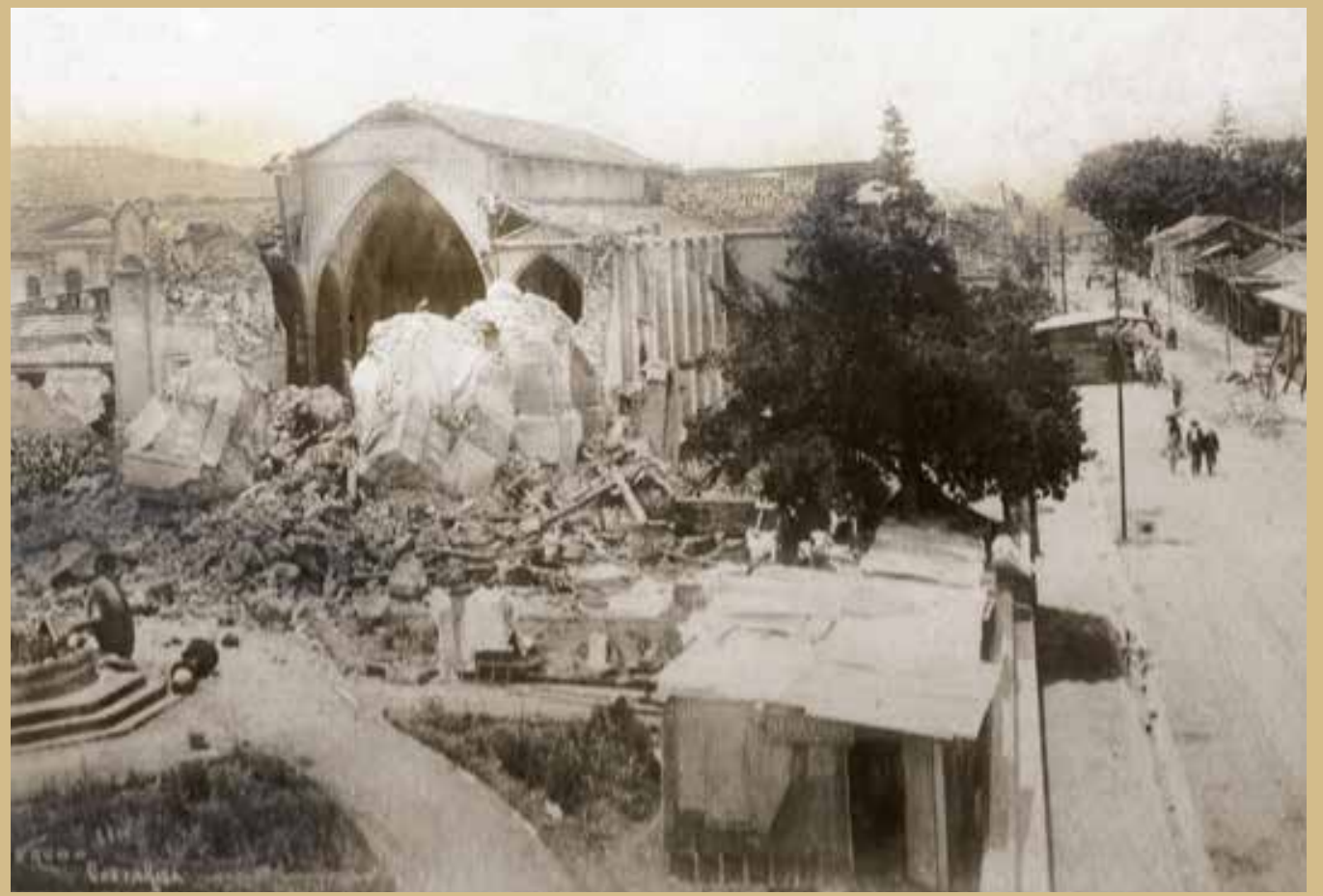

las dos se gestionaron simultáneamente, es posible que se tratara de fuentes del mismo modelo. Otro elemento en favor de esta teoría es que ambas estaban destinadas para lucir en plazas pequeñas de dimensiones muy similares, por lo que era perfectamente razonable que las fuentes fueran iguales.

En la foto siguiente podemos ver la Fuente de Delfines derribada por el efecto del terremoto de Santa Mónica. Como podemos advertir, la fachada del templo y paredes quedaron prácticamente en ruinas, no así su interior, que se mantuvo casi intacto (Brenes, 2012, p. 215). Se puede apreciar también que la taza superior (la más pequeña) de la fuente, yace en el suelo, con sus bordes rotos, a causa del impacto de la caída. Afortunadamente, la taza mayor no sufrió daños.

¿Qué ocurrió con estos tres iconos de la historia cartaginesa? ¿Desaparecieron totalmente? ¿Se conserva alguna de estas fuentes? ¿Nuestros antepasados fueron capaces de destruir o dejar perder estas valiosas y emblemáticas obras? ¿La Fuente de Delfines que se conserva hoy en la Plaza de la Basílica de los Ángeles es la misma que estuvo en La Soledad o es la de San Nicolás Tolentino, o bien una mezcla de las tres fuentes? Veamos cada caso en particular.

\subsection{Destino de la fuente de la Plaza Principal.}

La construcción del ferrocarril al Atlántico suscitó grandes transformaciones en todos los ámbitos de la sociedad costarricense. Corre 1886 y, en la sesión del 17 de junio de ese año, la Municipalidad de Cartago, respondiendo al espíritu de progreso que se respiraba en todo el país, tomó la decisión de convertir la Plaza Principal en un Parque. En ese mismo año, una compañía inglesa, con asiento en Londres, inicia la construcción del Mercado de Cartago. Recordemos que antes de esa fecha, la Plaza servía de mercado de la provincia, práctica que se realizaba desde la época colonial (6). Al construirse el mercado, es evidente que la plaza caería en desuso y abandono, como efectivamente ocurrió.

Para construir el parque, la Municipalidad solicitó a Mr. G. H. Letan, Ingeniero 
Jefe del Ferrocarril, elaborar un plano de aquel y hacerse cargo de su construcción. Sin embargo, el proyecto de parque, en principio, fue solo nominal porque la Corporación Municipal no disponía de fondos suficientes para emprender este gran proyecto.

No fue sino hasta marzo de 1889 cuando la Municipalidad "considerando que el desmantelamiento de la Plaza Principal no corresponde al rango de esta ciudad, entre las poblaciones de la República ni a los demás elementos que hoy promueven su adelanto y modifican su aspecto" (Actas Municipales de Cartago, 1889, fol. 105), acuerda convertir la plaza en un parque público, iniciar la construcción de una acera de granito que rodeara toda la cuadra, y aplicar al objeto el valor de la venta de dos propiedades municipales: la Pesa Vieja y el Solar de El Carmen (estimando un valor superior a los 500 colones por cada inmueble).

El parque se terminó de construir en el año 1892. Para octubre de ese año se termina la instalación de una elegante reja de hierro, que rodearía el parque. Importada de Bélgica, gracias al empeño del Presidente José Joaquín Rodríguez, la reja permanecería en el parque, por casi cuatro décadas. Actualmente, la reja centenaria luce, en perfectas condiciones, bordeando el edificio principal del Colegio de San Luis Gonzaga. En el acta municipal del 20 de octubre de 1892, se señala que:

... considerando que de la venta que se hizo de la casa del Pbro. don Gabriel del Campo, quedó a la municipalidad una utilidad de un mil ciento once pesos [...] y que destruida la fuente central del parque de esta ciudad, el buen aspecto de aquel exige que se llene el vacío que allí se nota... (Actas Municipales de Cartago, 1892, fol. 105. Ortografía actualizada).

Además de indicar explícitamente la destrucción de la fuente, este acuerdo se refiere a que los dineros obtenidos por la venta de la casa del Pbro. don Gabriel del Campo se destinaron para construir un kiosco en el sitio que ocupaba aquella (Actas Municipales de Cartago, 1892, fol. 194).

El acuerdo evidencia que la fuente fue destruida (¿quitada o trasladada?), antes del 20 de octubre de 1892. Es posible que la destrucción de esta se iniciara desde antes de 1889, cuando la Municipalidad denuncia el desmantelamiento de la plaza principal y acuerda construir allí un parque.

En enero de 1893, se aprueba un contrato con el Ingeniero italiano Enrico Invernizio Olivieri para construir un kiosco en el sitio que ocupaba la pila. Una cláusula del contrato obligaba al Ing. Invernizio a destruir las gradas de piedra de la antigua pila. Sin embargo, este contrato no se llevó a cabo, por enfrentamientos entre el Ing. Invernizio y el gobernador Demetrio Tinoco.

En enero de 1894 se firma un nuevo contrato con Guillermo H. Keith, para construir el kiosco, el cual queda totalmente acabado en el mes de febrero. El kiosco se asentó sobre el espacio que ocupaba la pila, y en lugar de demoler las gradas - como se había estipulado en el contrato con el Ing. Invernizzio- más bien se aprovecharon estas. En 1910, el kiosco fue afectado por el terremoto de Santa Mónica; pero quedó en pie. Sirvió para atender en él a personas heridas por efecto de la tragedia. En este kiosco falleció, en la fatídica noche del terremoto de Santa Mónica, el poeta Rafael Ángel Troyo Pacheco.

Finalmente, en el año 1920 se decide destruir este primer kiosco y construir uno totalmente nuevo, lo que tristemente implicaba la total demolición del antiguo kiosco, incluyendo la escalinata de piedra. Con este acto, se da fin al último vestigio que quedaba de la pila original de 1873: su preciosa y amplia escalinata de piedra de ocho ángulos, construida por don Juan Orlich, don José Quirze, don Luis Müller, y todos sus ayudantes. 

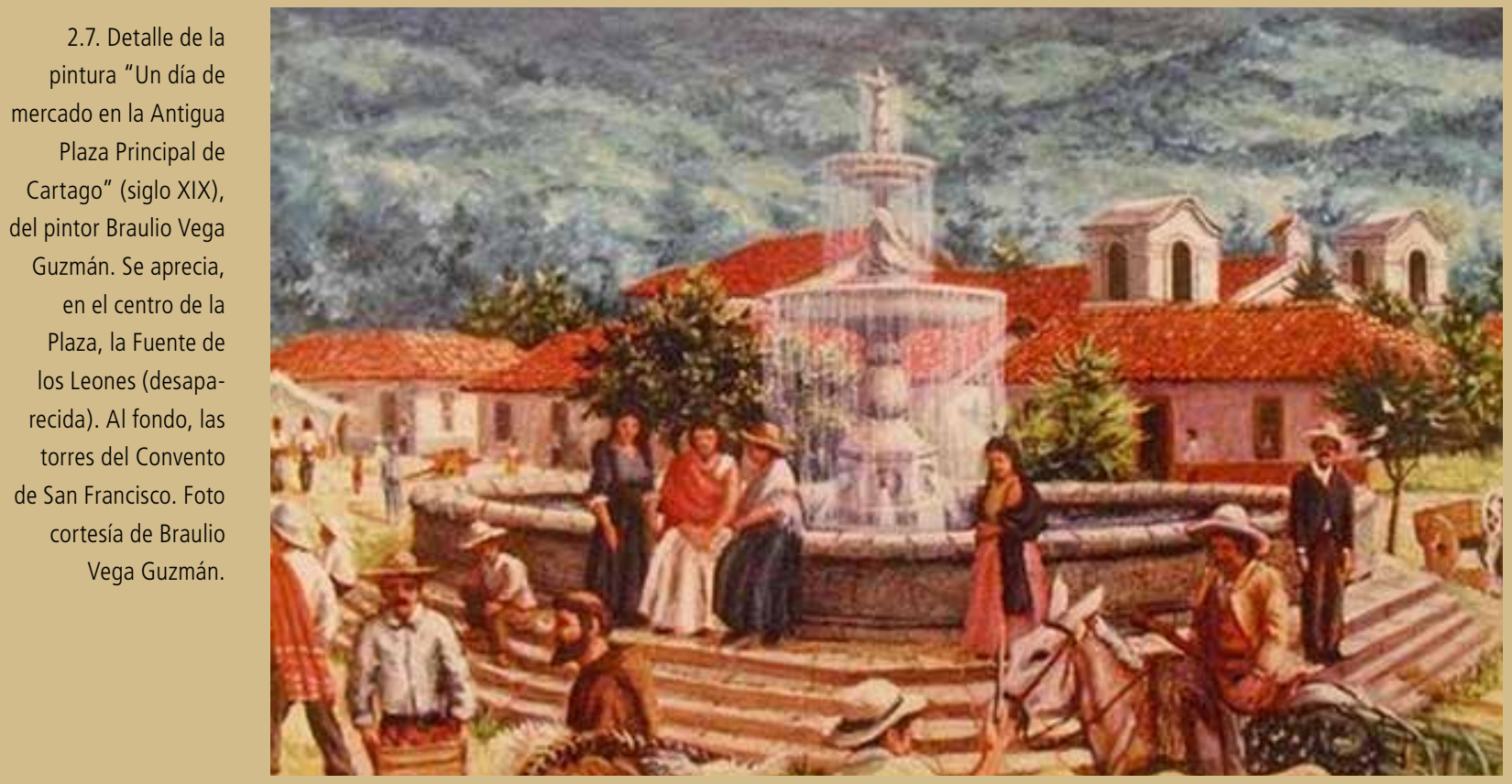

Nos cuesta mucho aceptar que los "viejos cartagos" - tanto los ciudadanos como las autoridades-fueran capaces de permitir la destrucción de su magnífica fuente, como si se tratara de un estorbo. Si ella era casi una reliquia, que simbolizaba junto con el alumbrado público- la más grande obra comunitaria de la provincia, en todo el siglo XIX

¿En qué momento y por qué motivo los cartagineses se volvieron en contra de esta obra, al extremo de destruirla? Aún hoy no sería extraño que un objeto como tal pudiera quedar en el olvido por falta de dinero para mantenimiento, o por simple negligencia pero, ¿por qué llegar al extremo de abatirla? Todavía es viable imaginar la demolición de la pila, o de una parte de ella pero, ¿cómo se pudo destruir una fuente de hierro de aspecto tan dominante, en el centro neurálgico de la ciudad?

El hierro colado (o fundición gris) posee una alta resistencia al desgaste, pero también una alta tensión de rotura, es decir que resulta poco dúctil y muy quebradizo ante los impactos, por ejemplo un golpe de mazo o una fuerte caída. Es posible que las tazas de la Fuente de Leones fueran dañadas o destruidas usando golpes de mazo (recuérdese que la taza menor de la Fuente de Delfines se rompió al caer, durante el terremoto); pero es casi imposible que con golpes de mazo se pudiera destruir el pedestal, y menos los delfines. Es harto difícil imaginar que tal atrocidad ocurriera, a vista y paciencia de las autoridades.

Pero realmente pudo ocurrir. Y para que ello aconteciera debió responder a alguna aversión o molestia que causara la fuente en los ciudadanos y hasta en las autoridades, como si se hubiera convertido ella en una espina para sacar a toda costa, y recuperar así la salud de la ciudad. Uno podría sospechar que este rechazo se originó antes de iniciarse la construcción del parque, es decir que al momento de arrancar los trabajos del parque (1889), ya la fuente de hierro estaría semidestruida o destruida del todo. Es factible pensar así, porque la construcción del kiosco (1892) responde al vacío antiestético que quedó en el centro del parque por la fuente en ruinas.

Si en dicho momento la fuente hubiera estado allí - tal vez sucia y descuidada, pero en pie-, cabe imaginar que los constructores del parque habrían preferido mantener en su sitio aquella imponente obra y remozarla. El parque de Cartago, 
con la impresionante Fuente de Leones y su maravillosa pila de piedra, no cabe duda, habría sido uno de los parques más majestuosos y bellos de la república.

\subsection{Destino de la fuente de La Soledad.}

Empezamos afirmando que no hay claridad acerca del destino de la fuente de La Soledad. No sabemos aún si fue destruida, o si fue "rescatada" por algún menesteroso del arte o por un dueño de lo ajeno, y se la habrá llevado a un sitio dentro de Cartago, o lejos de sus confines.

Lo único que sabemos con total certeza es que, a inicios del siglo $\mathrm{XX}$, las autoridades de la Iglesia de La Soledad colocaron, en el centro de la plazoleta, una cruz de piedra para "conmemorar el siglo feliz para la religión", es decir al cambiar el siglo XIX al XX. La cruz de piedra se colocó en el sitio "donde existía una fuente" (El Cartaginés, 1904, p. 2). De acuerdo con los datos anteriores, tenemos certeza de que en el sitio donde estuvo la fuente, se colocó una cruz de piedra para el cambio de siglo (1901). ¿Pero cuándo se quitó la fuente? ¿Ocurrió en el mismo cambio de siglo $o$ antes?

Para el mes de julio de 1897, las autoridades acuerdan trasladar una fuente pública provista de elegante surtidor (Diario de Costa Rica, 1897, p. 2) que se encontraba en la Plaza del Carmen, a la nueva Plaza Iglesias, donde se celebrarían los festejos agostinos. No tenemos certeza de cuál pueda ser esta fuente; sin embargo recordemos que, para esa fecha, las únicas dos fuentes públicas que había en la ciudad eran la de San Nicolás y la de La Soledad.

En sus Memorias, Mario Sancho (1961, p. 54) menciona que había una fuente en el patio interno del antiguo Colegio San Luis Gonzaga, pero juzgamos esta fuente más como privada que como pública. Y, además, don Mario la vio allí una vez cuando ingresó al Colegio San Luis Gonzaga, en el año 1903, razón por lo que descartamos que se trate de la fuente de La Soledad.

La fuente de San Nicolás se mantuvo en su sitio hasta que fue derribada en el terremoto de 1910, y por otra parte sabemos que la de La Soledad ya no estaba en su lugar, a inicios del siglo XX.

Por lo tanto, está dentro de lo probable que fuera la fuente de La Soledad la que se trasladó a la plaza de El Carmen, donde hoy está el Parque Jiménez. Y luego sería ubicada en la Plaza Iglesias, frente al costado oeste del edificio principal del Colegio de San Luis Gonzaga que, en ese entonces, se ubicaba al costado sur del Mercado Central.

En 1906, los primeros jugadores del recién fundado Club Sport Cartaginés jugaban en la Plaza Iglesias, pero aquella fuente "de elegante surtidor", colocada en el centro de la plaza, estorbaba sus prácticas, y era común que los jugadores tuvieran que sacar la pelota de la pila. De acuerdo con Rogelio Coto (1987, p. 84) ellos pidieron permiso a la Municipalidad para quitar la fuente, permiso que les fue concedido, y la fuente fue trasladada, al parecer, a la Plaza del Barrio El Carmen.

Complementariamente, podemos transcribir a dos autores que dejaron testimonio escrito de haber conocido de cerca la fuente de La Soledad.

Sancho (1933, p. 100), señala que la fuente de La Soledad se encontraba "en una Plazuela del Barrio El Carmen, orinecida y condenada al estado seco...". Treinta años más adelante, Jesús Mata (1970, p. 46) apoya el testimonio de Sancho, al afirmar que "Esa fuente - la de La Soledad- la hemos visto muy abandonada en un potrero por el lado del Carmen, como un chunche viejo" y abogaba por que la Municipalidad de Cartago la recuperara y la colocara en un sitio de honor, para la celebración del cuarto centenario de la ciudad, en 1964.

Pese a todo, no hemos encontrado aún testimonios escritos o gráficos que nos 
permitan dilucidar el enigma de su destino. Por el momento, solo nos es permitido afirmar, gracias al testimonio de don Jesús Mata Gamboa, que hacia el año 1964, la Fuente de La Soledad desapareció del predio donde quedó abandonada en el Barrio El Carmen y, al día de hoy, se desconoce su paradero.

\subsection{Destino de la fuente de San Nicolás Tolentino.}

A causa del terremoto de 1910, la fuente quedó mutilada: su taza superior rota y desprendida del cuerpo central; igual suerte corrieron los delfines con su peana, y el remate con sus amorcillos (putti) abrazados al cañón vertical del chorro de agua. En tal condición, fue llevada a un patio del plantel municipal, donde permaneció a la intemperie, por más de 20 años, revuelta entre rejas retorcidas de los balcones del viejo Palacio Municipal (Sancho, 1933, p. 100).

El artículo escrito por Sancho (1933), donde se quejaba del estado de abandono de las fuentes de La Soledad y de San Nicolás, pudo haber llamado la atención de las autoridades civiles o eclesiásticas.

En el año 1935 se celebraron los trescientos años del hallazgo de la Virgen de los Ángeles, lo cual constituyó una efeméride de grandes proporciones en Cartago y en toda Costa Rica. La Municipalidad se encargó de embellecer e iluminar el parque de la Basílica, y el elemento decorativo central, en dicho lugar, fue la Fuente de Delfines, reparada para esta ocasión tan especial.

En la parte derecha de la imagen 2.8., se aprecia la Fuente de Delfines en el centro del parque de la Basílica, el día viernes 2 de agosto de 1935. Observe que la taza superior aparece en su sitio y sin fisuras, lo cual denota que fue cambiada o reparada. Además, ya no están los cupidos o amorcillos (putti) ni el remate, como perfectamente se aprecian en la foto de Henry G. Morgan, en la plaza de San Nicolás Tolentino, en 1892.

La fuente lució en el centro de la plaza de la Basílica de los Ángeles, hasta mediados de la década de 1940, cuando la quitaron. Fue retirada antes de la celebración del Congreso Eucarístico del 2 de agosto de 1946, pues hay registros fotográficos de

2.8. Foto tomada de la película oficial del Tricentenario, filmada por don Walter Bolandi (lamentablemente la película se encuentra desaparecida). Se aprecia la Fuente de los Delfines, en el centro del parque de los Ángeles, el 2 de agosto de 1935 Fuente: Carlos Borge C, Tricentenario de Nuestra Señora de los Ángeles (1935).

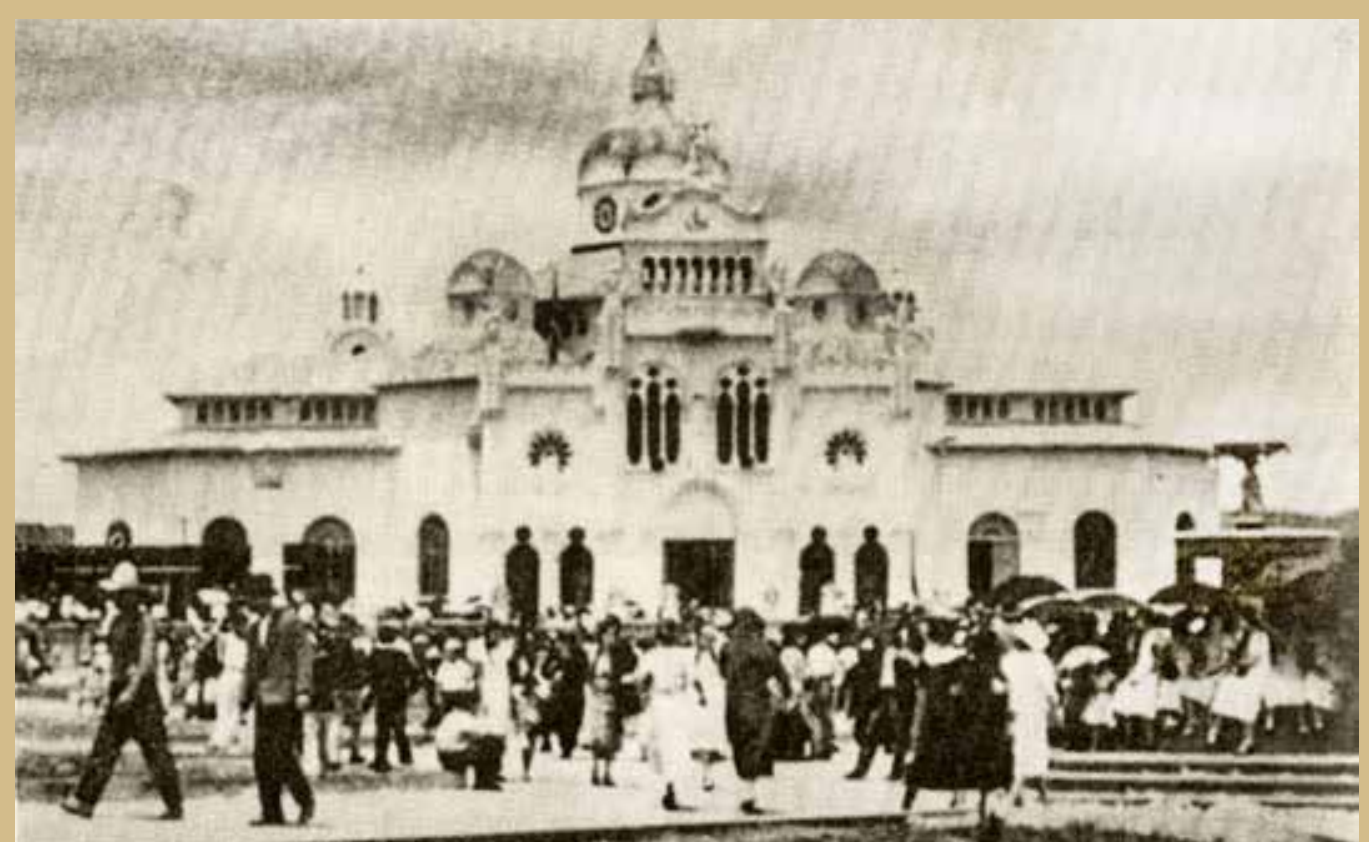

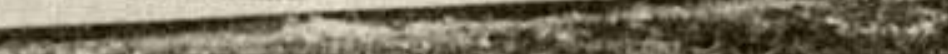


la magna celebración en el Parque, en los cuales claramente se aprecia que ya no estaba la fuente en su centro.

Después de ello, la fuente estuvo guardada en unas bodegas y reaparece en 1955, cuando la instalan en el recién inaugurado Balneario Municipal, en el Barrio El Carmen. Pero hay un detalle especial: la taza superior es totalmente diferente a la que tenía antes de 1946; sin embargo, sí es una taza original del fabricante, aunque perteneciente a otro modelo de fuente. Asimismo, le fue recortado el borde lobulado, seguramente con el fin de que guardara proporción, pues con dicho borde, la taza habría desentonado en el conjunto de la fuente. ¡Una verdadera lástima la manera en que se

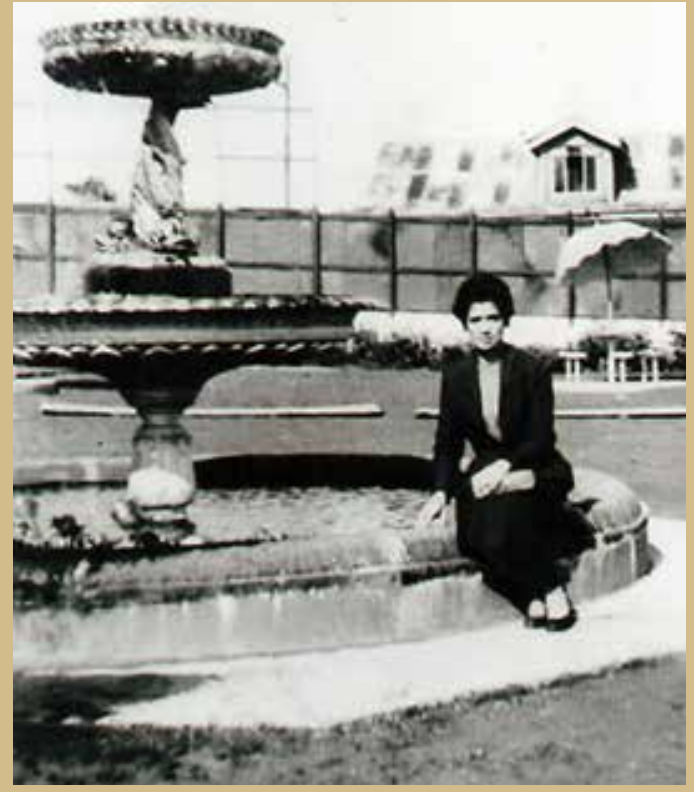
mutiló la taza superior!

Una década después, cuando el balneario entró en decadencia, la fuente es retirada de dicho lugar y se traslada al entorno de Los Ángeles, pero sin una ubicación pública. No fue sino hasta la década de los ochenta del siglo XX cuando es colocada de nuevo en el centro del Parque de Los Ángeles.

En el año 1994 se realizó una profunda transformación de todo el entorno frente a la Basílica y se sustituyó el parque por una plaza:

El principal objetivo de estos cambios era brindar un mayor espacio, mejor ambiente y comodidad a los visitantes, y sobre todo a los millares de estos que se congregan al final de la tradicional romería practicada el 1 de agosto de cada año.

(Gómez, 2007, p. 80)

Tales cambios implicaron, entre otras cosas, el traslado de la fuente. Afortunadamente, el traslado fue apenas de unos metros, al extremo oeste de la misma plaza. Se le hicieron mejoras como la construcción de una pila de cemento con su reja, y se puso nuevamente a funcionar, por medio de una bomba eléctrica.

Lamentablemente, la fuente de hierro fue objeto de "retoques" innecesarios, que lejos de embellecerla, ocultaron partes importantes, entre extrañas hemiesferas de cemento, que hoy lucen muy deterioradas. Hasta la misma marca del fabricante pudo quedar sepultada entre el cemento. Aun con este error tan garrafal, es justo reconocer que se hizo un esfuerzo por preservar la fuente e incorporarla al

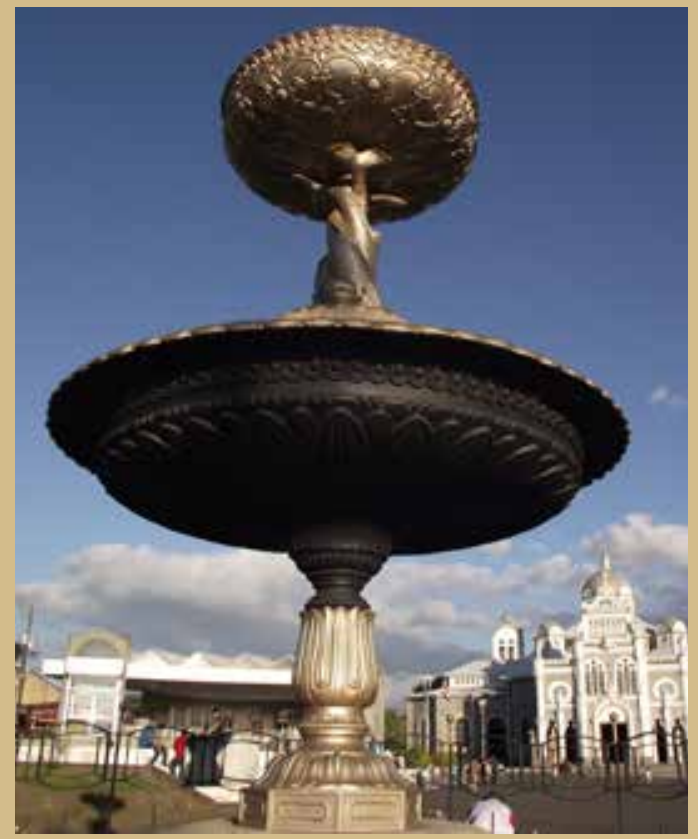

2.10. Fuente de los Delfines, en la plaza de la Basílica de los Ángeles. Foto: Sergio Orozco Abarca (2012). fines en el Balneario

Municipal de Cartago, entre 1955-1965. Foto de autor desconocido, colección: Sergio Orozco Abarca 
conjunto de la nueva plaza. De hecho, la Plaza de la Basílica tiene, en sus extremos, dos obras históricas y patrimoniales, que parecen mirarse y admirarse mutuamente: la Basílica misma y la Fuente de Delfines.

Actualmente, la fuente se encuentra en franco abandono. La pila está cuarteada e inservible: la bomba no funciona y, en consecuencia, la fuente tampoco. La Fuente de Delfines de Cartago pide a gritos una intervención urgente por parte de las autoridades pues, de lo contrario, podría correr la misma suerte que sus dos hermanas y perderse para siempre o sufrir daños irreparables.

\section{7. ¿Es la Fuente de Delfines en Los Ángeles, la antigua fuente de San Nicolás Tolentino?}

Como hemos mencionado, tanto Mario Sancho como don Jesús Mata Gamboa testifican que la Fuente de La Soledad estuvo abandonada, durante mucho tiempo, en un predio en el barrio El Carmen. Hemos dicho, también, que no existen testimonios ni registros de ella, desde el año 1964. En cuanto a la Fuente de San Nicolás, Sancho (1933, p. 100) explica que esta se encontraba tirada y rota, junto con los balcones del Palacio Municipal, y hace referencia al daño ocurrido a dicha fuente en el terremoto de 1910. Con base en los datos disponibles hasta el momento, se pueden establecer algunas conjeturas, como las siguientes:

a. que la fuente de la plaza de Los Ángeles (Fuente de Delfines) es la fuente de La Soledad. Esta es una posibilidad que no se puede descartar del todo; pero el testimonio de Mata (1970) de que la Fuente de La Soledad estaba tirada en un potrero del Barrio El Carmen, debilita esta posibilidad, puesto que en 1964, la Fuente de Delfines actual se encontraba en el Balneario Municipal.

b. que la fuente de la plaza de Los Ángeles (Fuente de Delfines) se ensambló con partes de dos o quizás de las tres fuentes. Siempre cabe la posibilidad de imaginar que en 1935 se reconstruyera la fuente usando partes de la Fuente de La Soledad y de la Fuente de San Nicolás. Por ejemplo, que al quebrarse la taza superior de la Fuente de San Nicolás (durante el terremoto) la hayan sustituido por la taza - presumiblemente intacta- de la Fuente de La Soledad. También se puede elucubrar que la Fuente de Leones no fuera destruida en su totalidad, y que en algún sitio

2.11. Fuente de Delfines en la plaza menor de la iglesia San Nicolás Tolentino. Detalle del plano en que se ilustra la inundación de Cartago, el 27 de octubre de 1891. Álbum de Figueroa: Archivo Nacional de Costa Rica, imagen: 1-025-f. Modificación: Sergio Orozco Abarca (2015).

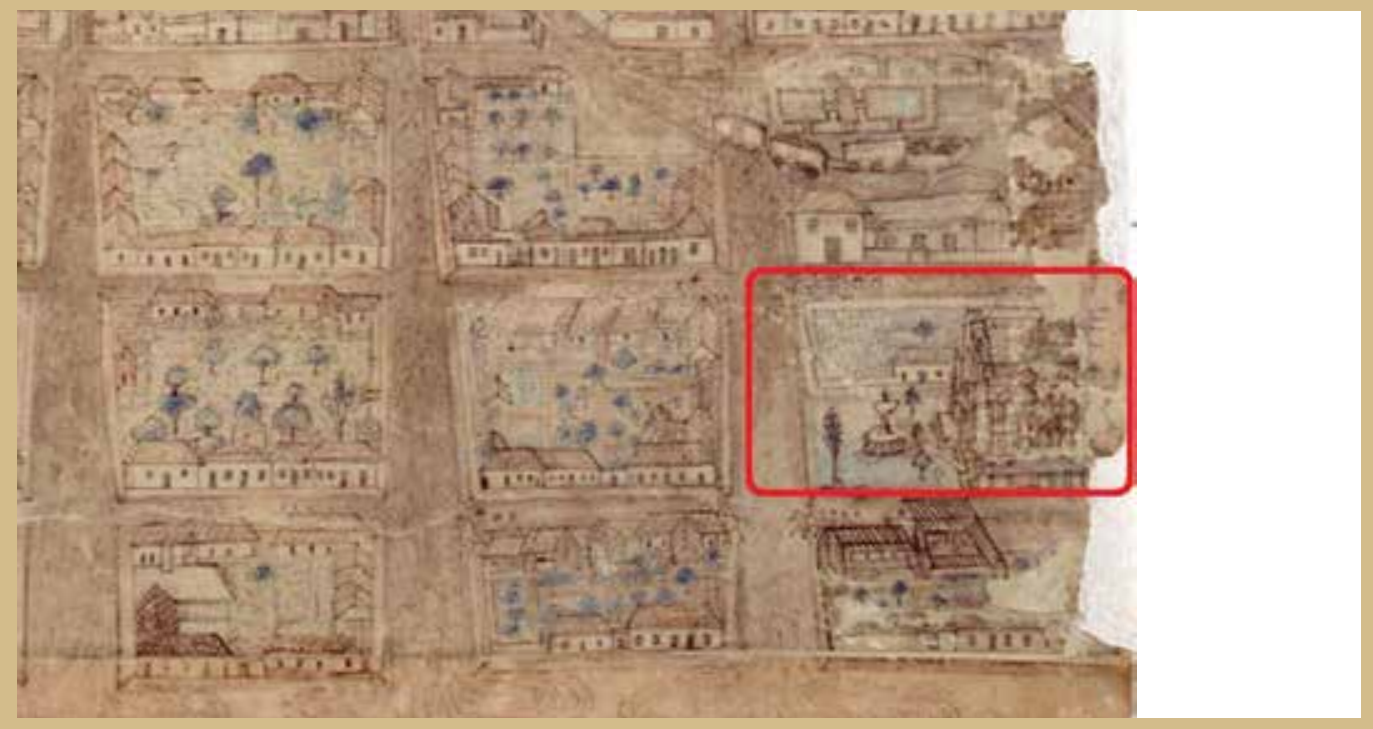


quedaran partes aprovechables, para implantarlas, luego, en la Fuente de Delfines, por ejemplo la taza superior. Sin embargo, todas estas ideas parecen poco probables, porque aunque las imágenes de la Fuente de La Soledad son escasas, sí permiten advertir que la taza superior y el remate - con los putti-eran idénticos a los de la Fuente de San Nicolás. El problema radica en que la taza original -correspondiente al modelo del fabricante- es notoriamente diferente a la taza actual. Asimismo, el testimonio de don Jesús Mata (1970, p. 46), se indica que la fuente de La Soledad estaba abandonada en un potrero del Barrio El Carmen, en 1964; pero no indica que le faltaran partes. En cuanto a la posibilidad de que se hayan usado partes de la Fuente de Leones, no hay ningún rastro o evidencia de ello. Sin embargo, considerando que tanto los delfines, como las tazas y los putti eran idénticos en las tres fuentes, no se puede descartar esa posibilidad, por curiosa que parezca.

c. que la fuente de la plaza de los Ángeles (Fuente de Delfines) es la misma Fuente de San Nicolás Tolentino. Esta conjetura es mucho más probable y nos sentimos más seguros y atraídos por ella, dado que Mario Sancho declara que la fuente de San Nicolás (que él vio en 1933) estaba rota por los daños que sufrió en el terremoto. Adicionalmente, disponemos de material gráfico para probar que efectivamente la fuente de San Nicolás - al menos su taza superior - se quebró en el terremoto. Asimismo, la Fuente de Delfines - hoy en la plaza de la Basílica de los Ángeles- tiene una taza superior diferente de la original, lo cual evidencia que este ornamento fue cambiado en fecha posterior. La única razón lógica para cambiar la taza es a causa de un daño o desaparición de esta. Por lo tanto, es altamente probable que se trate de la misma fuente. Sería ideal contar con datos más concretos (escritos u orales) que nos permitan dilucidar este enigma en un ciento por ciento; pero desafortunadamente aún no disponemos de ellos. Sin embargo, por el momento, nos parece más lógica esta conjetura y nos plegamos a ella.

\subsection{Fabricante y procedencia de las fuentes de Cartago.}

Para conocer la marca del fabricante y la procedencia de un objeto antiguo, se dispone de varios criterios. Los más ortodoxos son: a) buscar la marca del fabricante en algún sitio de la obra; b) buscar evidencia documental (factura, guía de importación o exportación, noticia en un periódico, acta municipal o memorándum, etc.) donde se mencione la marca y procedencia; c) buscar el modelo en los catálogos originales de los fabricantes (si están disponibles), y d) opinión de una persona u organización experta en la materia.

En el caso de las fuentes de Cartago y Heredia, trabajamos sobre la base del tercer criterio; en el caso de las dos fuentes de San José, utilizamos los cuatro criterios. Hacemos la salvedad de que el tercer criterio puede inducir a error, puesto que -en algunos casos-, los modelos podían ser copiados entre fundiciones, especialmente cuando se trataba de reproducción en serie de esculturas antiguas. Sin embargo, muchos fabricantes ponían en los modelos dentro de los catálogos, la leyenda: "Diseño registrado" o "Diseño exclusivo", con lo cual resulta más que evidente que un determinado diseño pertenece a un fabricante. Pero aunque no exista esa leyenda, si en diferentes documentos se hace constante referencia a una obra como propia de un fabricante en particular, estamos ante una posibilidad muy alta de que la manufactura sea de este y no de otro.

Hecha la salvedad anterior y -ante todo- por el hecho de tener en nuestro poder copia del catálogo original del fabricante, podemos afirmar, casi con total 
2.12. Gran puente de hierro sobre el río Pacuare, fundido en Inglaterra por Andrew Handyside \& Co. Foto de autor desconocido, recuperada de: http://

crtrenes.blogspot. com/2010/10/puentesobre-el-rio-pacuare. $\mathrm{html}$

2.13. Puente Handyside sobre el río Matina, con un peso 600 toneladas y un costo superior

a los $\$ 100,000$

Imagen tomada de

"La llustración, revista hispanoamericana", Barcelona 1888. No. 423, 9 de diciembre de 1888. p. 423.
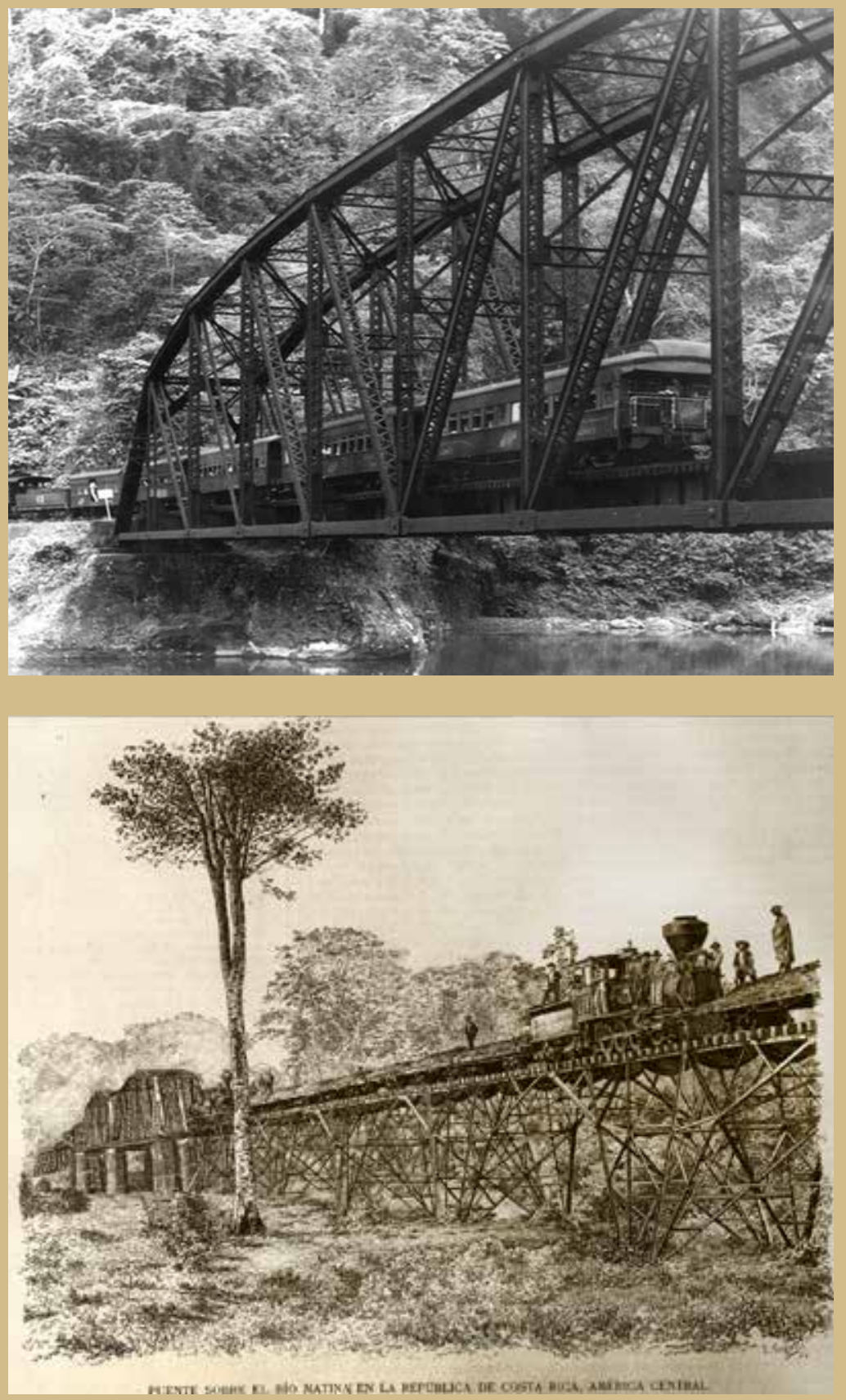

certeza, que las tres fuentes de hierro de Cartago y las dos de Heredia fueron fundidas en Inglaterra por Britannia Iron Works (también conocida como Britannia Foundry), firma perteneciente a Andrew Handyside \& Co., de Derby, cuyo fundador nació en Edimburgo, Escocia, en 1805 y falleció en 1887.

Andrew Handyside \& Co. será una de las fundidoras más importantes del Reino Unido, en toda la época victoriana. Adquirió enorme reputación gracias a las fuentes, ornamentos para jardín y jarrones de hierro, antes de aventurarse en la fabricación de puentes para ferrocarriles. Fue una de las primeras empresas en producir los famosos buzones de correo, tan pintorescos en

Inglaterra. Posteriormente, en la década de 1850 inició la fabricación de estructuras arqueadas, que servirían para construir puentes y otro tipo de estructuras prefabricadas en hierro (por ejemplo mercados, galpones, muelles, etc.), tanto para el Reino Unido como para exportar a todo el mundo. La compañía cesó sus operaciones en el año 1910, apenas unos meses después del terremoto de Cartago.

La firma Andrew Handyside no fue desconocida en Costa Rica pues, aparte de las fuentes de Cartago y Heredia, tenemos la suerte de contar con otras valiosas obras de su prestigiosa fundición; entre ellas, los puentes de hierro para el ferrocarril sobre los ríos Pacuare y Matina, en el Atlántico. 


\section{9. ¿Cómo era la Fuente de Delfines?}

En el catálogo C de la Handyside \& Co, de 1879, encontramos datos valiosísimos relacionados con estas fuentes. Para el caso de la Fuente de Delfines (las piezas artísticas en hierro), ahora sabemos, entre otras cosas, que su código de fabricación era el No. 12 (ilustrada en la página 17 del catálogo), que contaba con 9 pies y 8,5 pulgadas de altura (295,91 centímetros), desde el pedestal hasta el cañón del chorro de agua, y que su precio era de $f 55$ (7), sin incluir el costo del embalaje, flete, etc.

Otros datos interesantes son que la fuente más barata del catálogo tenía un pre-

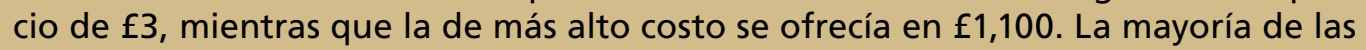
fuentes se entregaban sin pintar, para que el cliente las pintara luego a su gusto. Sin embargo, con un cargo adicional, algunos modelos se podían entregar pintadas en bronce o mármol, o también en bronce y oro. Por el aumento en el costo, es probable que las de Cartago vinieran sin pintar.

\subsection{0. ¿Cómo era la Fuente de los Leones?}

Para el caso de la Fuente de Leones (las piezas artísticas en hierro), ahora sabemos de ella que su código de fabricación era el No. 19 (ilustrada en la página 16 del catálogo), que medía 12 pies y 16,5 pulgadas de altura $(407,67 \mathrm{~cm}$.), desde el pedestal hasta el cañón del chorro de agua, y que su precio era de $f 72$ con 10 chelines, sin incluir el costo del embalaje, flete, etc. (Handyside \& Co, 1879).

Adicionalmente, la pila completa —incluyendo la escalinata de piedra-tenía un ancho de 16 metros aproximadamente y la altura total del conjunto superaba los 5 metros.

\subsection{Otros ejemplares en el mundo.}

¿Hay ejemplares de los modelos No. 12 y No. 19 en otras partes del mundo? Afortunadamente sí. En los jardines del Museo Rossendale, en Whitaker Park, condado de Lancashire, Inglaterra, se encuentra un ejemplar de Fuente No. 12, prácticamente igual a la Fuente de Delfines de Cartago (imagen 2.14).

Estas imágenes nos permiten apreciar el hecho curioso de que la Fuente Rossendale (al igual que la Fuente de Delfines de Cartago) carece del remate característico del modelo No. 12: los cupidos (putti) abrazados al cañón del chorro de agua. Probablemente, estos elementos se dañaron o fueron trasladados a otro sitio.

El otro aspecto relevante es que la taza superior de la Fuente Rosensale es el original correspondiente a este modelo. Gracias a ello podemos apreciar cómo era la taza superior original de la Fuente de Delfines, lo cual evidencia que la taza actual de dicha fuente en Cartago sustituye a la original, dañada en el terremoto de Santa Mónica. También podemos advertir que los

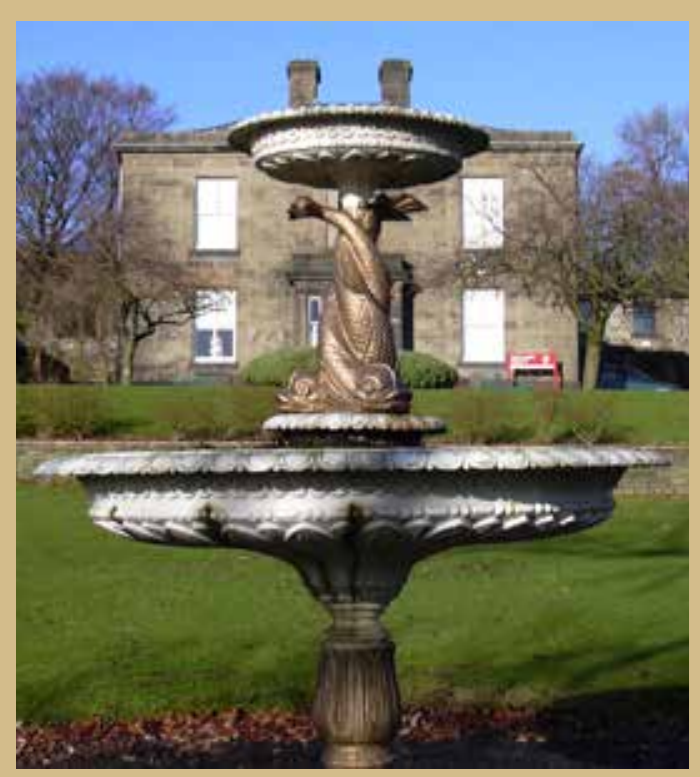

(7) Este era el precio de la fuente en libras esterlinas del año 1879. Las fuentes adquiridas por la Municipalidad de Cartago, pudieron costar un poco menos, puesto que en 1872 , las actas municipales señalan que recientemente hubo un incremento importante en el precio del hierro, a nivel mundial.
2.14. Fuente de Delfines de Rossendale, en Whitaker Park. Foto cortesía de Robert Wade (2008). 
2.15. Fuente de

Canta, en Perú. Foto

cortesía de www.

LimaTuristica.com.

Recuperada de http://

www.limaturistica. com/2014/09/foto-

pileta-de-la-plaza-de-

armas-de.html.

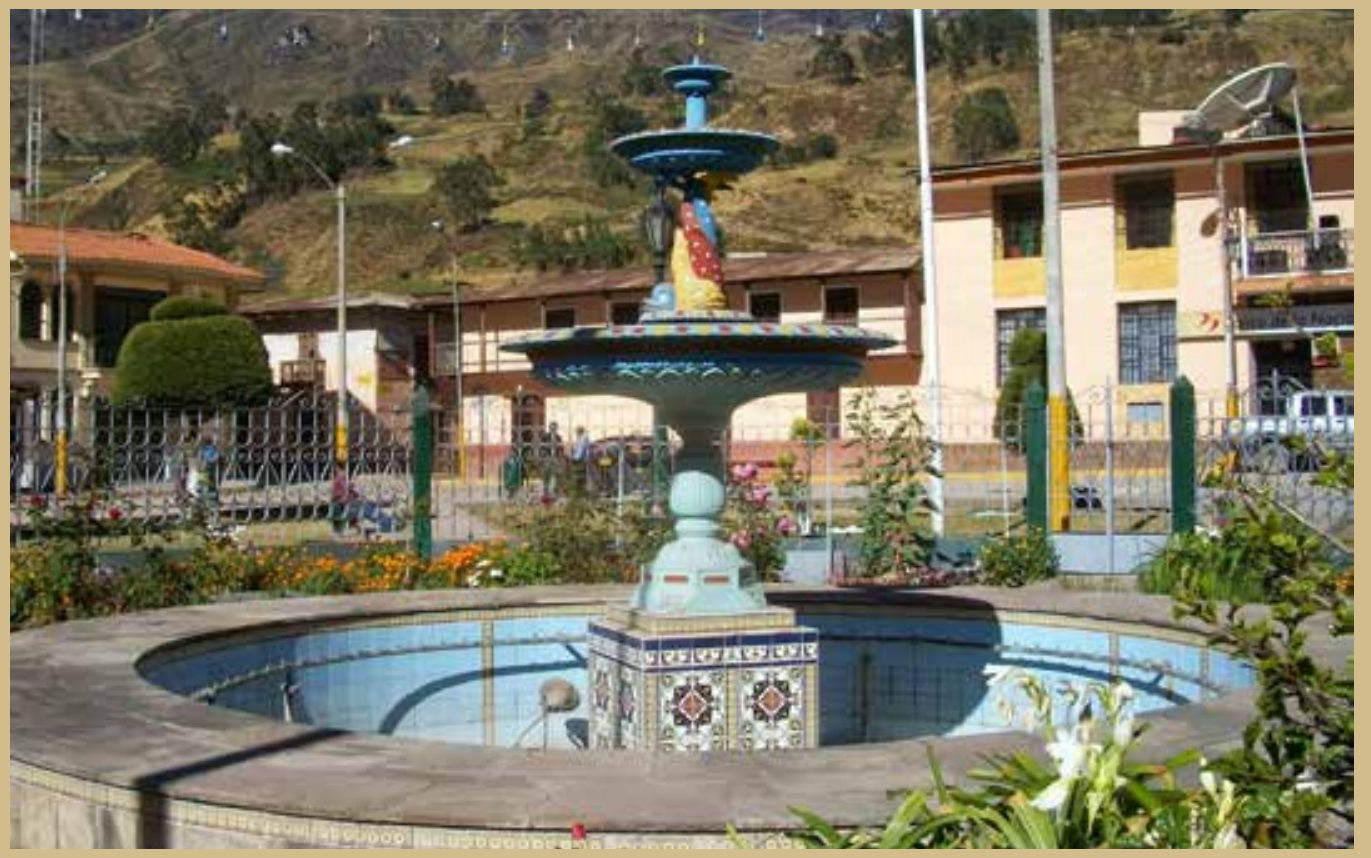

delfines descansan sobre una peana cónica, que se asienta sobre la taza mayor; en el caso de la Fuente de Delfines, dicha peana está oculta dentro de una hemiesfera de cemento, en la desacertada restauración de 1994, por lo que no es posible apreciarlo del todo.

En la Plaza de Armas de Canta, provincia del Departamento de Lima (Perú) encontramos una fuente del mismo modelo No. 12.

Asimismo, quiso la fortuna que la Fuente de Delfines de Cartago tuviera una hermana gemela en otro lugar de Costa Rica. Se trata de la Fuente de Delfines que se encuentra en el Parque Manuel María Gutiérrez, frente a la Iglesia de El Carmen, en la Provincia de Heredia. De ella hablaremos en el apartado correspondiente a las fuentes de esta provincia.

2.16. Fuente sur del Temple Newsam en Leeds, fabricada por Andrew Handyside \& Co. (c. 1894). Foto cortesía de Andrew Gallon/Feversham Media (2010)

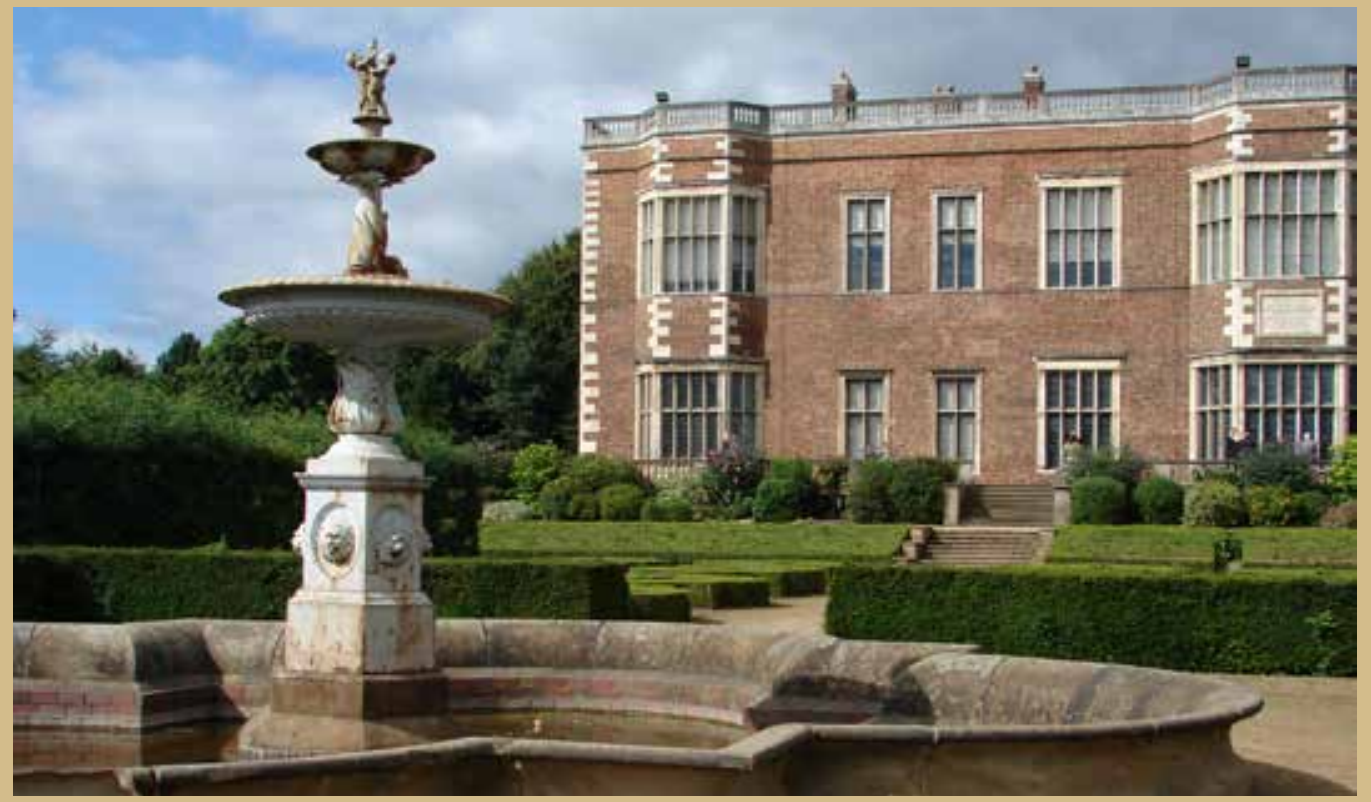


Así las cosas, con las dos Fuentes de Delfines de Costa Rica, más las fuentes Rossendale (Inglaterra) y de Canta (Perú), apenas llegamos a cuatro ejemplares conocidos de este modelo. A ella deberíamos sumar la Fuente de La Soledad, de Cartago, cuyo paradero se desconoce desde la década de 1960.

Por fortuna, hay varios ejemplares del modelo No. 19 que gozan de muy buena salud en otras latitudes del planeta, porque personas responsables y visionarias supieron preservarlas para las generaciones futuras. Gracias a estos ejemplares y a los datos disponibles en el Catálogo Handyside, podemos saber cómo era exactamente la desaparecida Fuente de Leones de Cartago. Hay ejemplares de ella en Rosenkildehuset, Stavanger, Noruega; en La Plaza de la Independencia de San Miguel de Tucumán, Argentina; en Caraz, provincia de Huaylas, departamento de Ancash, Perú; y dos conocidas en Inglaterra: una en Cripplegate Park, en Worcester, y otra en el Temple Newsam, en Leeds.

En el jardín sur del Temple Newsam, una mansión TudorJacobina en Leeds, al norte de Inglaterra, encontramos su bien conservada fuente Handyside, modelo No. 19 (Imagen 2.16). Con similar majestuosidad y altivez, lució la famosa Fuente de Leones, en la Plaza Principal de Cartago, desde 1873 y hasta 1889 , aproximadamente.

En la imagen 2.17. se aprecia el remate completo, conformado por los dos putti (amorcillos) abrazados al cañón vertical, del cual brota el chorro de agua (Handyside, 1879). Es necesario destacar acá que el modelo 12 (Fuente de Delfines), como el modelo 19 (Fuente de Leones) tenían remates idénticos: a partir de la taza mayor, todo es igual en ambos modelos. La actual Fuente de Delfines de Cartago, lamentablemente carece de él, pues se desprendió de su conjunto en el terremoto de Santa Mónica y no hay noticias, hasta hoy, de lo que habrá ocurrido con esta parte de la obra.

Finalmente, la imagen 2.18. muestra el detalle de los leones en el pedestal de la fuente. La foto corresponde a la fuente en la Plaza de la Independencia, de Tucumán, Argentina. Otro aspecto fundamental acá es que la marca del fabricante se incluyó en uno de los seis lados del pedestal de hierro, justo debajo de las cabezas de los leones: A. Handyside \& Co, Derby.

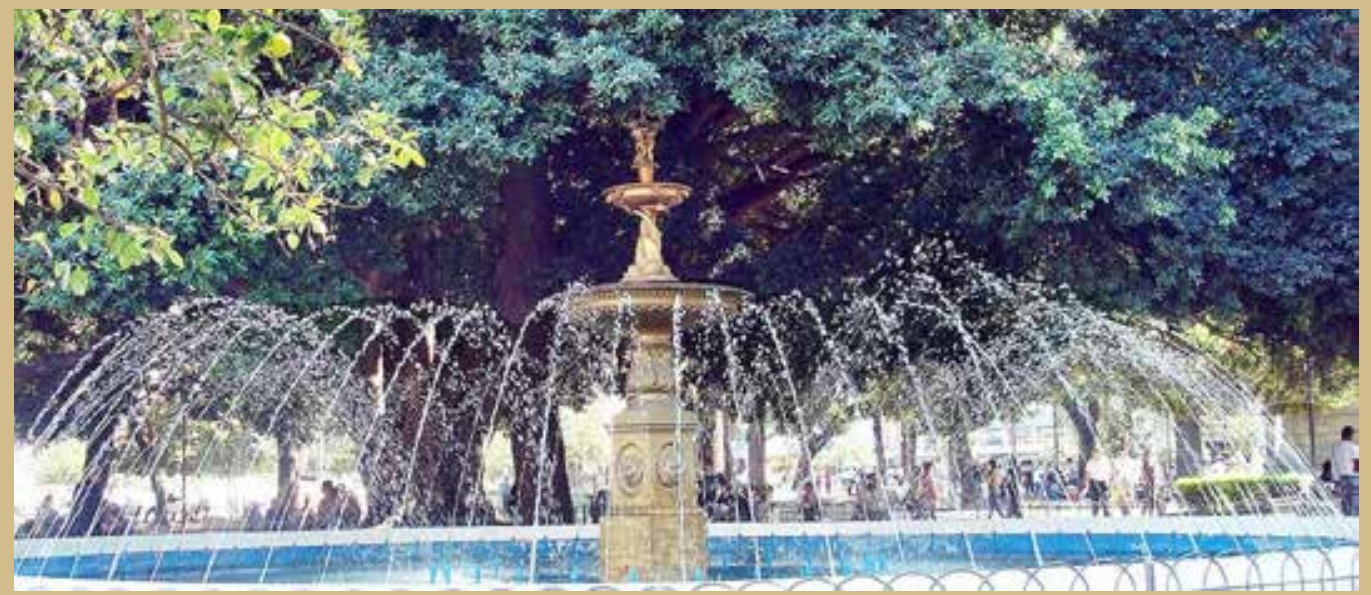

2.17. Detalle del remate de la fuente del Temple Newsam, con sus elementos superiores: taza menor, peana, los putti y el cañón de agua. Foto cortesía de Tim Green (2011).

2.18. Detalles del pedestal de la Fuente de Leones, en la Plaza de la Independencia de Tucumán, con marca del fabricante. Foto cortesía de Lucía Juárez (2011).
2.19. La Fuente de Leones en la Plaza de la Independencia de Tucumán. Foto cortesía de Lucía Juárez (2011). 
La imagen 2.19. muestra la fuente de la Plaza de San Miguel de Tucumán, como luce actualmente. Esta fuente ha permanecido en su lugar desde 1872, un año antes de que se instalaran las fuentes de Cartago. Por suerte para los tucumanos, la fuente se preservó, y hoy se ve lozana en el centro de su plaza.

De no haber intervenido los errores de nuestros antepasados - de los cuales tenemos que aprender siempre - hoy nos deleitaríamos con nuestra Fuente de Leones embelleciendo el corazón de la Vieja Metrópoli.

\section{[3] Fuentes victorianas de Heredia (1878).}

En 1877, la Municipalidad de Heredia adjudicó al Ing. John H. Brealey, la construcción de la primera cañería de la ciudad (Meléndez, 2001, p. 70).

Para celebrar esta grandiosa obra, en el año 1878, se dispuso colocar una fuente en la Plaza Principal y otra en la plazoleta de la Iglesia de El Carmen. Ambas piezas de hierro se compraron en Inglaterra.

Segura y Sánchez (2012, p. 37) cuenta que Brealey encargó la construcción de las pilas de mampostería y la instalación de las fuentes "al italiano Martín Parini, quien las rodeó con gradas de piedra de granito, traída de Cartago, mediante un trabajo en el que fue auxiliado por dos peones durante doce días". Complementa Sánchez esta información, indicando que en materiales - piedra, arena, cal, ladrillo- se gastaron 439 colones; por este trabajo, Martín Parini recibió 60 pesos de sueldo, y los dos peones, 24 pesos cada uno. El trabajo de construcción de las pilas, gradas de piedra e instalación de las fuentes de Heredia se inicia a mediados de julio, y se completa en agosto de 1878.

\subsection{La fuente en la Plaza Principal de Heredia (Fuente del Centenario o Fuente de los Tritones).}

Una vez instalada la fuente en la Plaza Principal, aquella lucía pequeña y desamparada en un espacio tan grande. Por esta razón se encargó a Manuel Víctor Dengo Bertora, ingeniero mecánico del ferrocarril, modificar la pila de mampostería y hacer los cambios necesarios, para que la fuente adquiriera más altura y se apreciara desde todos los ángulos de la plaza.

Con este propósito, Dengo diseñó una pila de metal (en forma de tazón), sobre la cual se asentaría la fuente de hierro. Según Segura y Sánchez (2012, p. 37), aunque Dengo realizó los diseños de la pila de metal (tazón) y la modificación de la pila externa, los constructores de la obra fueron don Eulalio González y don Nicolás Hernández. Sin embargo, un problema importante se suscitó al momento de instalar la fuen-

3.1. Placa de la Fuente del Centenario. Foto cortesía de Eduardo Sánchez.

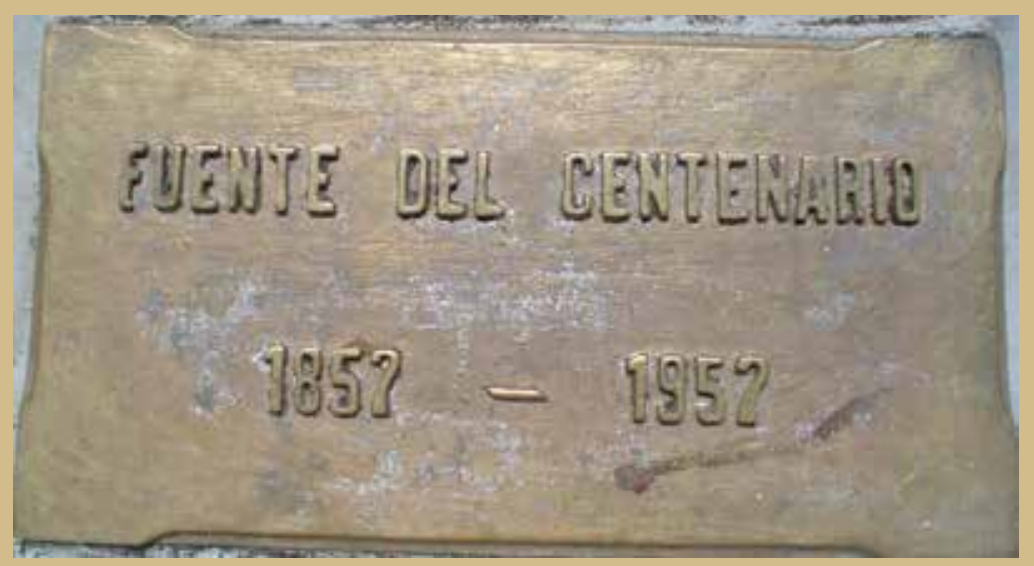
te sobre la pila metálica porque, debido al gran peso de la fuente, algunas partes de ella se quebraron $y$, en consecuencia, la Municipalidad tuvo que encargar la reparación de dichas piezas a la Fundición de San José (Segura 
y Sánchez, 2012, p. 38).

En abril del año 1957, con el propósito de conmemorar el centenario de la rendición de William Walker y los filibusteros, la municipalidad decidió bautizar la fuente con el nombre de Fuente del Centenario, y para ello colocaron una placa alusiva en su base. Dicha placa se encuentra actualmente sumergida en el agua, y obviamente no la puede apreciar el público.

La Plaza Principal de Heredia fue convertida en parque, que posteriormente fue bautizado como Parque Nicolás Ulloa Soto. El conjunto de elementos arquitectónicos ubicados en dicho sitio (la fuente de hierro con su pila, el kiosco y otros monumentos) fue declarado de interés histórico y cultural, por el Ministerio de Cultura de Costa Rica, mediante decreto número $23683-\mathrm{C}$ del 13 de octubre de 1994.

Felizmente, en el 2012, la Municipalidad de Heredia destinó fondos para restaurar la fuente, labor que finalizó con gran éxito, en 2013, la restauradora Ana María Moraleda. De este modelo, se conocen, a la fecha, cuatro ejemplares en otros países: Australia, Filipinas, Chile, Perú. A ellas nos referiremos más adelante.
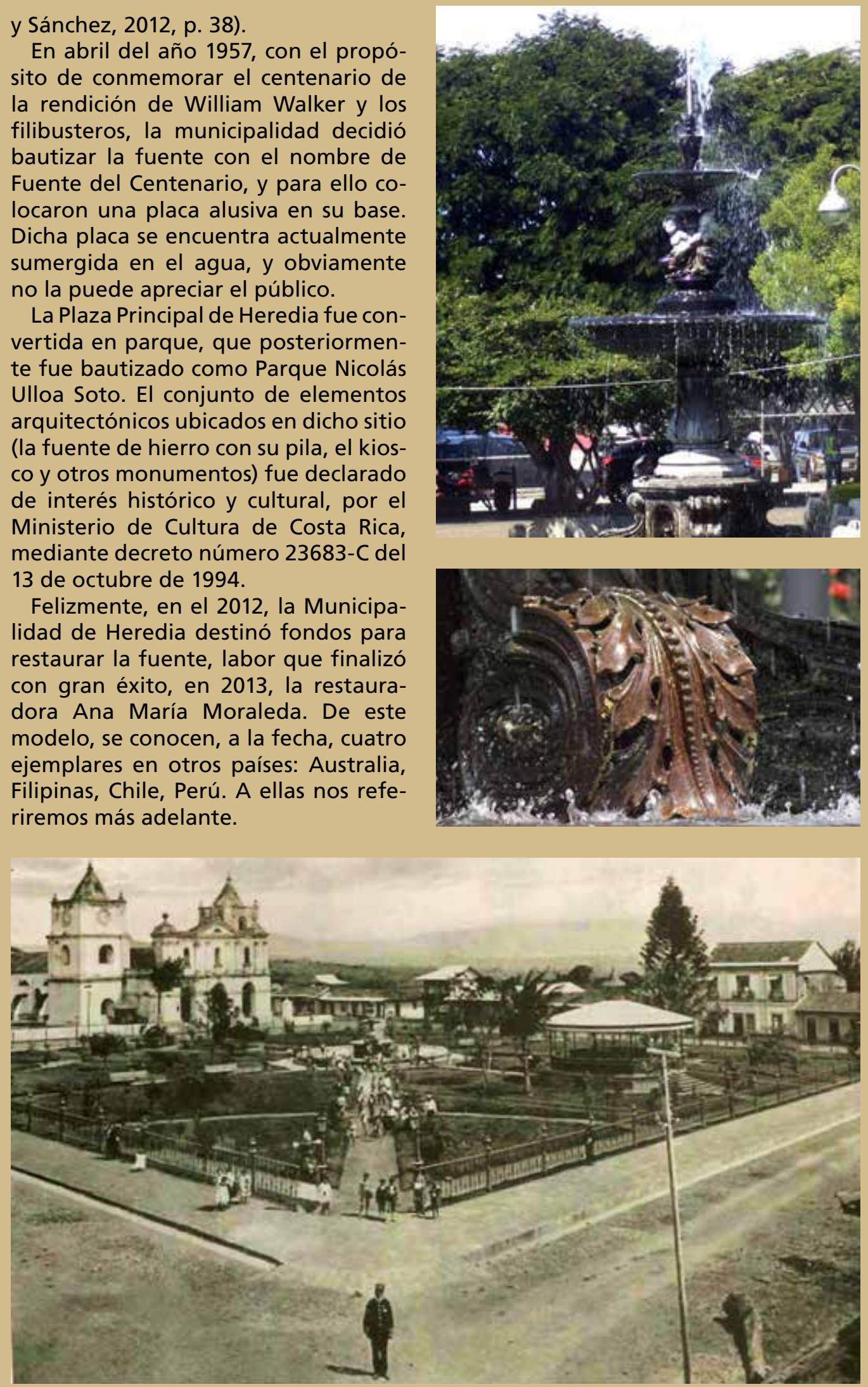

3.2. Fuente del Centenario en el Parque Nicolás Ulloa de Heredia. Foto cortesía de Eduardo Sánchez (soloheredia.blogspot. com, 2015).

3.3. Detalle de la Fuente del Centenario, en Heredia. Foto: Sergio Orozco Abarca (2011).
3.4. Parque de la ciudad de Heredia a inicios del siglo $X X$. En el centro, se aprecia la fuente de hierro. A la izquierda, el templo parroquial de la Inmaculada Concepción. Foto: Fernando Zamora. 
3.5. Fuente de Delfines de la plaza de El Carmen, hacia 1968.

Obsérvese que en esta época la fuente estaba completa, con su taza superior y los putti. Foto de autor desconocido, publicada en la página de Facebook Heredia

Ciudad Eterna.

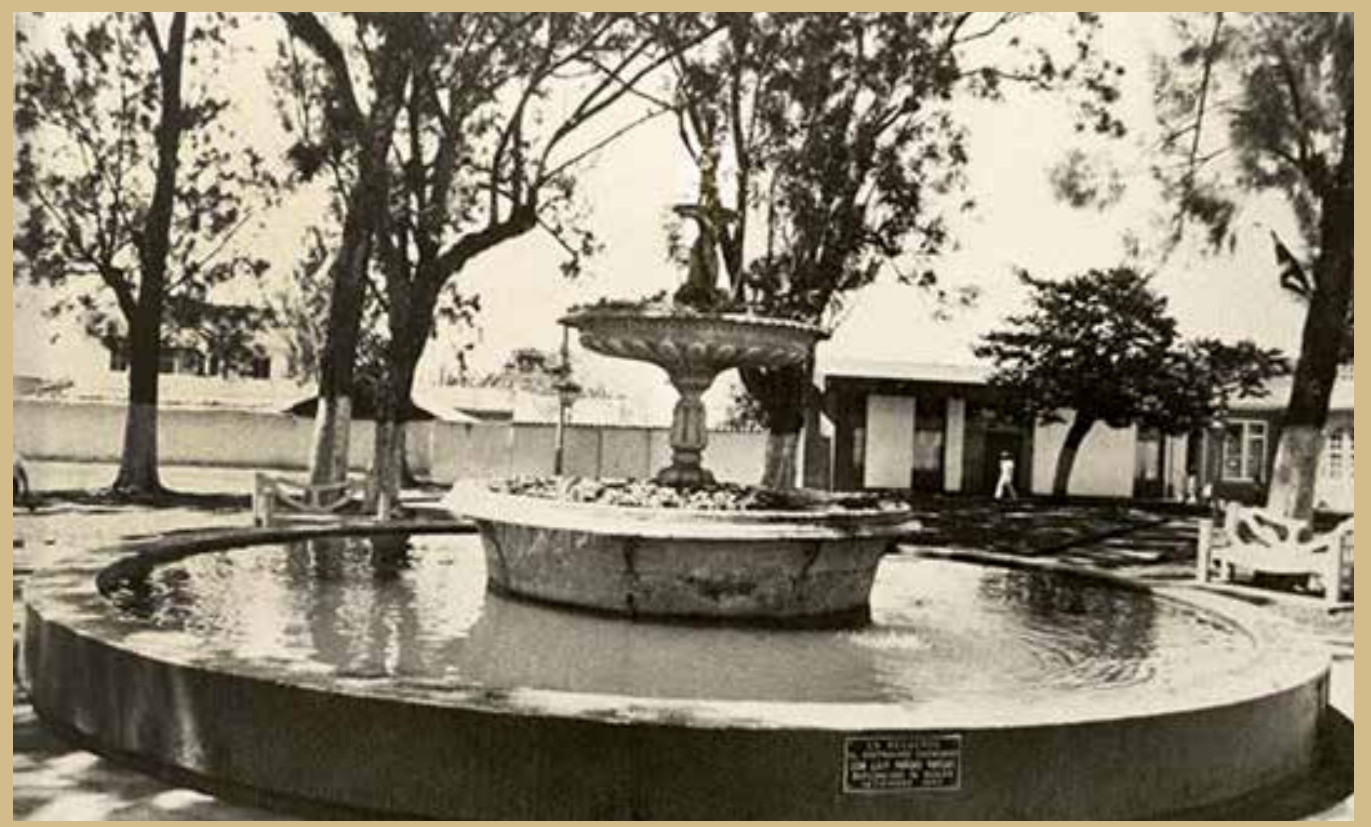

\subsection{La fuente en la plaza de la iglesia de El Car- men (Fuente de Delfines).}

El templo El Carmen de Heredia se ubica en avenida 4, entre calles 1 (Tranquilino Sáenz Ulloa) y 3 (Ing. Manuel Benavides Rodríguez). Su plazoleta fue construida para dotar al templo de un área para celebrar las fiestas de la patrona, la Virgen del Carmen.

En 1891, la Municipalidad decide convertir aquella plaza en un parque, y en 1924 de nuevo se acondiciona esa área para parque. En 1929, para celebrar el natalicio de Manuel María Gutiérrez, autor de la música del Himno Nacional de Costa Rica, se coloca allí un busto del artista, fabricado por el escultor cartaginés Juan

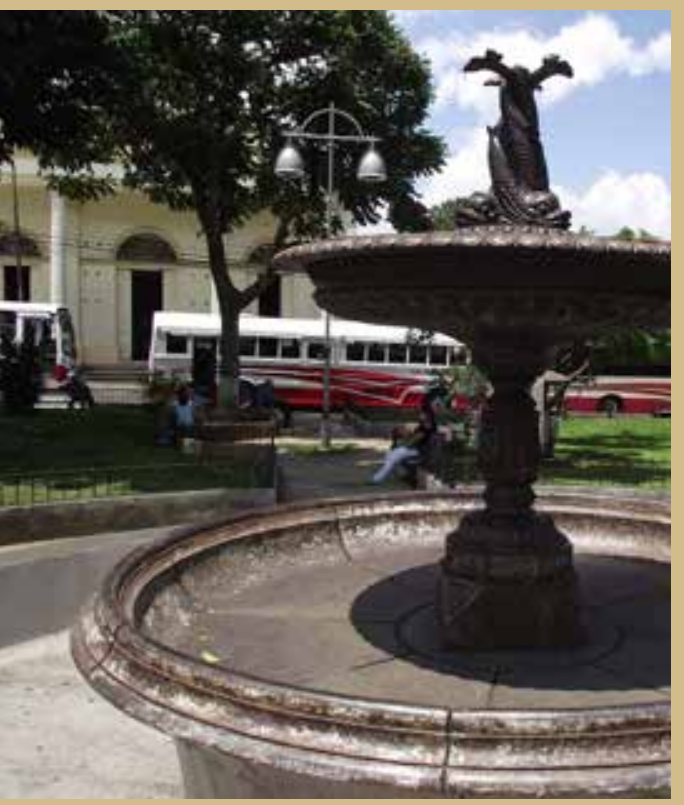
Ramón Bonilla. Desde entonces, recibe el nombre de Parque Manuel María Gutiérrez.

La fuente de hierro fue colocada cuando ese espacio aún era una plaza, antes de 1891. Curiosamente, al igual que la fuente de la plaza principal (Fuente del Centenario), a esta se le construyó una especie de tazón metálico, para que el conjunto adquiriera mayor altura, de manera que los ciudadanos la apreciaran desde puntos lejanos, dándole a esta mayor distinción y señorío (Meléndez, 2001, p. 113).

Durante mucho tiempo esta fuente estuvo en total abandono, luciendo en estado tan precario que constituía una amenaza a la salud de los transeúntes. Segura y Sánchez $(2012$, p. 38) cuentan que en el año 1900 -a poco más de 
diez años de haberse instalado-, por moción del regidor Nicolás Cartín, la Municipalidad ordenó destruir la fuente y guardar lo que se pudiera. Afortunadamente, la destrucción propuesta por el regidor Cartín no se materializó $y$, en su lugar, se decidió trasladar la fuente a la Plaza Iglesias, hecho que tampoco llegó a concretarse.

La hostilidad del regidor Cartín hacia la fuente no era más que reflejo del odio que los vecinos del barrio El Carmen sentían por ella, puesto que constituía un estorbo enorme para celebrar allí las famosas fiestas populares con sus corridas de toros (Segura y Sánchez, 2012, p. 38). ¿Acaso sería el "odio al estorbo" la misma razón para la destrucción de la Fuente de Leones, de la plaza principal de Cartago?

Por fortuna, la Fuente de Delfines de la plazoleta de El Carmen de Heredia se preservó. En 2014 fue restaurada con tal cuidado, que se le repusieron los elementos faltantes: la taza menor, los putti con su respectiva peana y el cañón vertical del chorro de agua. Todos estos elementos fueron esculpidos y fundidos localmente, con base en datos tomados de otros modelos No. 12, así como datos del catálogo original del fabricante. También se construyó una nueva pila externa, con una reja protectora.

\subsection{Fabricante y pro- cedencia de las fuentes de Heredia.}

Con base en los estudios descritos en el apartado 2.8. Fabricante y procedencia de las fuentes de Cartago, podemos afirmar, casi con total certeza, que las tres fuentes de hierro de Cartago y las dos de Heredia fueron fundidas en Inglaterra por Britannia Iron Works (también conocida como Britannia Foundry), firma perteneciente a Andrew Handyside \& Co., de Derby. Poco hay que agregar al respecto, más de lo ya expuesto en la sección mencionada.
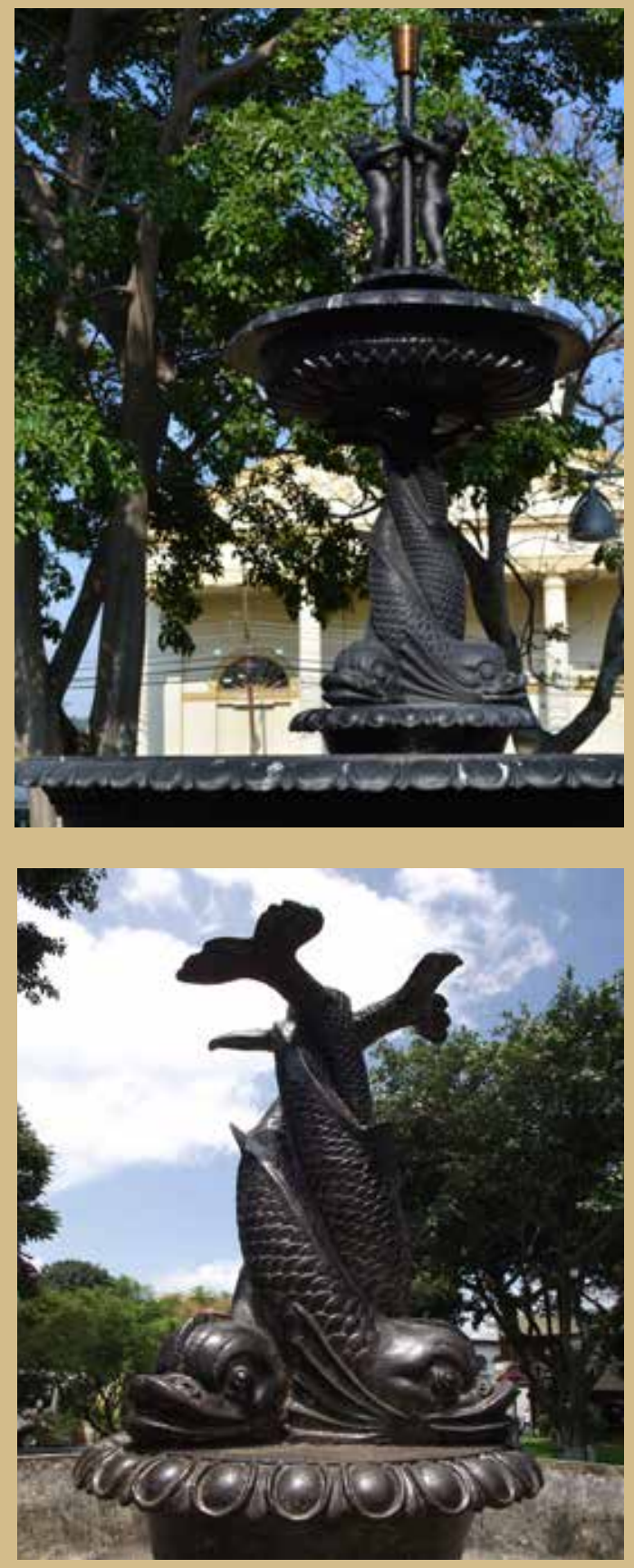

3.8. Detalle de la Fuente de los Delfines de Heredia, antes de la restauración. Obsérvese la peana cónica en que descansan los delfines. En la fuente de Cartago, dicho pedestal fue cubierto con un domo de cemento. Foto: Sergio Orozco Abarca (2011).

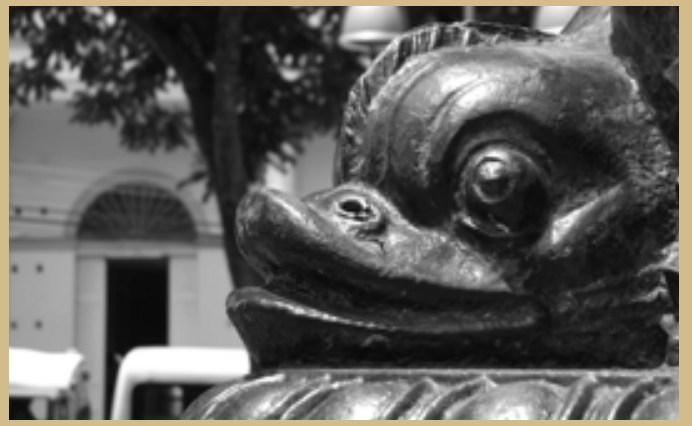

3.9. Detalle de la Fuente de los Delfines de Heredia. Foto: Sergio Orozco Abarca (2011). 


\section{4. ¿Cómo era la Fuente del Centenario en la Pla- za Principal de Heredia?}

Gracias al Catálogo de Handyside de 1879, sobre la fuente de la plaza principal (las piezas artísticas en hierro), sabemos que su código de fabricación era el No. 38 (ilustrada en la página 15 del catálogo); con una altura de 11 pies $(335,28$ centímetros), desde el pedestal hasta el chorro de agua, y que costaba $f 140$, sin incluir el costo del embalaje, flete, etc. De las cinco fuentes Handyside adquiridas en Costa Rica para conmemorar las cañerías, esta fue la de más alto valor monetario.

\section{5. ¿Cómo era la Fuente de Delfines de la plaza de El Carmen?}

La fuente de la plaza de El Carmen corresponde al modelo No. 12 del catálogo C de Handyside, por lo tanto es igual a la Fuente de los Delfines de Cartago, que hoy se conserva alterada en la plaza de la Basílica de los Ángeles. De igual manera, era gemela de la fuente de la antigua iglesia de La Soledad, también de Cartago, cuyo paradero se desconoce.

Así las cosas, ahora sabemos que en Costa Rica se compraron tres fuentes del modelo número 12: dos en Cartago y una en Heredia. De modo que la Fuente de Delfines de la plaza de El Carmen, es igual a la ya expuesta en el apartado 2.9.

\subsection{Otros ejemplares en el mundo.}

Tal como se dijo en el apartado 2.11. sobre otros ejemplares en el mundo de las fuentes de Cartago, hay un ejemplar del modelo No. 12 (Fuente de Delfines), en los jardines del Museo Rossendale, en Whitaker Park, condado de Lancashire, Inglaterra. Y hay otro en la Plaza de Armas de Canta, Departamento de Lima, Perú.

En cuanto al modelo No. 38 existe un ejemplar en la Plaza de Armas de San Carlos, provincia de Ñuble, Chile; otra en Cresswell Gardens, en Adelaida, Australia (ima-

3.10. Fuente de

Cresswell Gardens en Adelaida, Australia.

Donada por Alfred Müller Sympson (18431917), en el año 1904

Foto cortesía de http:// adelaide-in-photos. blogspot.com/

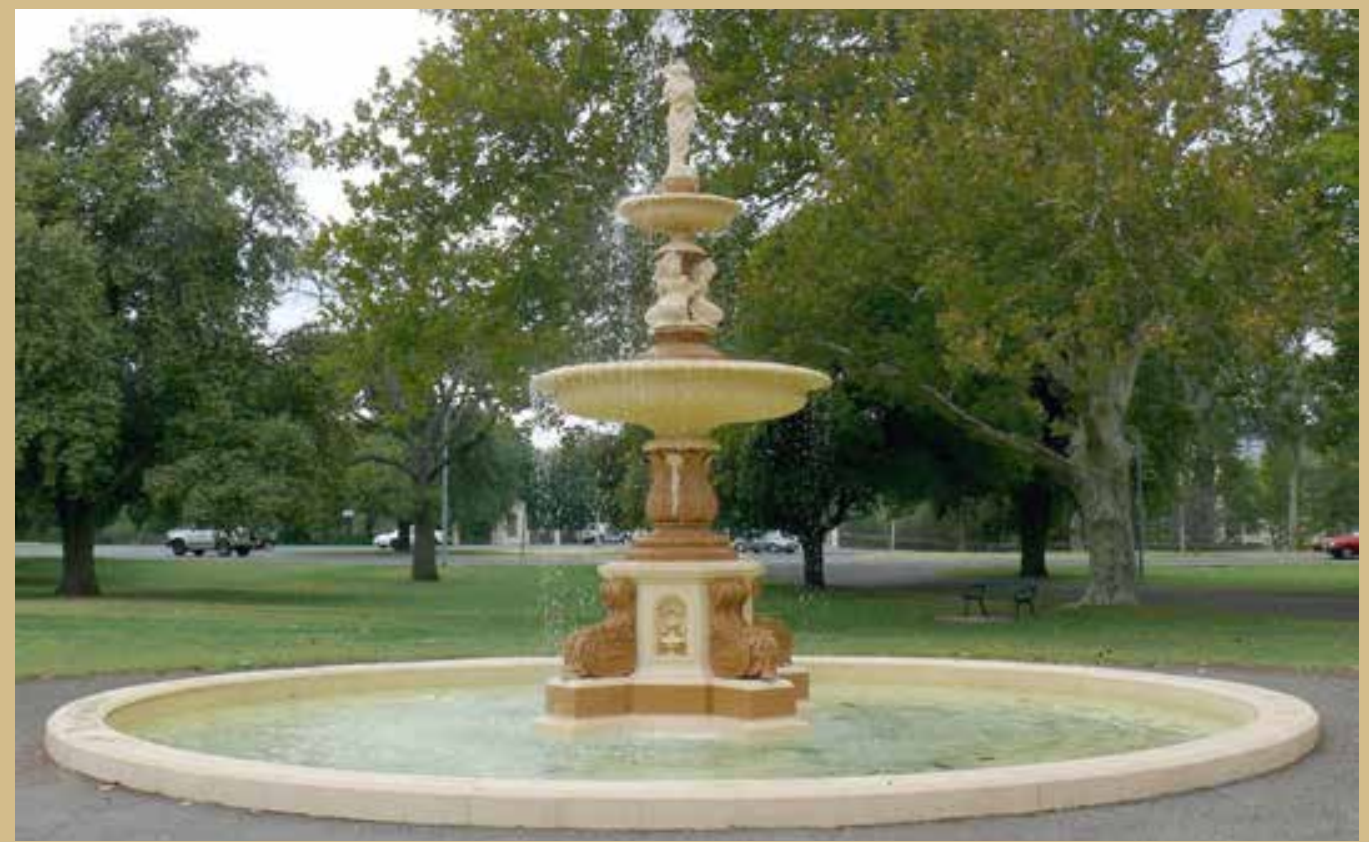


gen 3.10); otra en San Mateo de Huánchor, provincia de Huarochirí, Departamento de Lima, Perú; y otra en la Plaza San Lorenzo Ruiz, en Binondo, Filipinas.

Como puede notarse, la fuente Cresswell Gardens de Adelaida es casi idéntica a la Fuente del Centenario de Heredia. En el caso de la fuente Cresswell Gardens, su remate lo conforma una ninfa, que porta un ánfora, de la cual brota el chorro de agua. En el modelo no. 38 del catálogo Handyside no se incluye esta ninfa; pero un motivo similar forma parte del remate del modelo 36. La Fuente del Centenario es una fuente modelo 38 estricto; por lo tanto, dudamos mucho que tuviera, en su remate, una ninfa similar a la fuente Cresswell Gardens.

Hay dos detalles que diferencian a la Fuente del Centenario del modelo original del catálogo: el plato superior y el remate. En la fuente del catálogo, la taza superior es igual a la de la Fuente de Delfines (modelo No. 12); pero en la Fuente del Centenario, la taza es similar - o idéntica- a la del modelo No. 41 del catálogo.

De igual manera, el remate de la Fuente del Centenario carece del cobertor metálico en su punta, que tapaba los pequeños tubos de los que brotan los chorros de agua. En el modelo original No. 38, dicho cobertor estaba formado por un grupo de hojas verticales, de un pie de altura, atadas en ramillete.

\section{[4] Fuentes victorianas de Alajuela (1880).}

De todas las fuentes victorianas conocidas en Costa Rica, las únicas que tienen estampada la marca del fabricante son la Fuente de Moisés, en los tanques de agua de Barrio Aranjuez (obra de Coalbrookdale), y las tres fuentes de Alajuela. "R. Laidlaw \& Son, Engineers \& Contractors, Glasgow" reza la placa adosada al pedestal en las tres fuentes escocesas de Alajuela. No obstante, hay múltiples razones para poner en duda que esta firma sea la fabricante de las tres obras.

Hagamos un brevísimo viaje al origen de estas fantásticas esculturas para conocer un poco de sus trámites de ingreso. Efectivamente, en el artículo primero de la sesión municipal del 16 de enero de 1879, se indica que la Municipalidad de Alajuela solicita al Supremo Gobierno que este realice el pedido de materiales de cañería, especificados en carta del ingeniero constructor de la obra, Emanuelle Theodor Moller, noruego de nacimiento, dirigida "a los señores Laidlaw and Son, de Glasgow, Escocia". (Actas Municipales de Alajuela, 1879, Exp. 5138, fol 3.).

Desde 1873, Moller trazó el primer plano de la cañería, que fue aprobado por el Ing. Ángel Miguel Velázquez, y su primera oferta a la Municipalidad la hizo el 17 de abril de 1877. En esta oferta, Moller no solo propuso adquirir los mejores materiales disponibles en Europa y realizar importantes adelantos en todo extremo, sino también culminar la obra colocando siete fuentes, que superaran en cantidad a las fuentes inglesas de San José, Cartago y Heredia, y rivalizaran con estas en belleza: seis "en las esquinas de la ciudad...y una en la plaza principal" (Municipal, Exp. 15266, fol 13.). Al final, por razones de presupuesto, únicamente se colocaron tres, ordenadas, una cada quinientos metros, en un plano inclinado de noroeste a sureste.

Robert Laidlaw \& Son era ya una firma centenaria cuando Alajuela, con el apoyo económico y logístico del Supremo Gobierno del general Tomás Guardia, compró la cañería en 1879. La empresa fue fundada en Edimburgo alrededor del año 1788, y contaba con operaciones en Glasgow y Londres. En el índice de firmas que participaron en la Exhibición Internacional de Ciencias, Arte e Industria (Glasgow, 1888), se indica lo siguiente sobre esta compañía:

Las diversas obras en Glasgow aumentan sus grandes dimensiones y cubren un extenso número de hectáreas. Estas obras están dedicadas principalmente a la 
(8) "The various works in Glasgow aggregate to large dimensions, and cover a considerable number of acres of ground.

These works are largely devoted to the manufacture of cast-iron pipes, for which the house maintains an unsurpassed reputation, and their equipment for this purpose is in every respect first-class, every facility being possessed for the most effective conduct of an industry of this important kind. The combined productive capacity of the foundries is very great, giving employment to a large number of workmen". (Recuperado de http://www. glasgowwestaddress.

co.uk/)

4.1. Imágenes del catálogo de George Smith \& Co. (finales de la década de 1860). A la izquierda el modelo No. 39, correspondiente a la fuente de la plaza del Cementerio; al centro, el modelo No. 38, correspondiente a la fuente de San Gerardo; y a la derecha, el modelo No. 2, correspondiente a la fuente del Parque Central. Imágenes cortesía de The Scottish Ironwork Foundation. Composición: Sergio Orozco Abarca. fabricación de tubos de hierro fundido, de una reputación sin igual, y su equipo para este propósito es, en todos los aspectos, de primera clase [...] La capacidad productiva de sus fundiciones es muy grande, y proporciona empleo a gran número de trabajadores (8).

Todas estas dimensiones y capacidades sorprenden al saber que Alajuela se decidió por un proveedor de esta categoría mundial para su cañería. Al revisar la oferta de productos de R. Laidlaw, encontramos una vasta producción de componentes o hardware (medidores de gas, hidrantes, máquinas de vapor, muelles, tuberías de hierro); pero ninguna producción de hierro ornamental o arquitectónico (cráteras, bancas, farolas, edificios y tampoco fuentes). Entonces surge la pregunta: ¿Cómo es posible que en Alajuela haya tres fuentes Laidlaw, pero en ningún documento de la compañía encontramos registro de que la empresa fabricara este tipo de obras.

\subsection{Fabricante y procedencia de las fuentes de Alajuela.}

Lucía Juárez (www.LuciaJuarez.com), arquitecta argentina experta en estructuras escocesas de hierro colado, residente en Edimburgo, nos dio una mano. Ella nos puso en contacto con la Scottish Ironwork Foundation, entidad especializada en la difusión de la magnífica obra de fundiciones escocesas en el mundo. Solicitaron fotografías de las fuentes y sus placas. Al cabo de varios días, nos entregaron un dictamen tan sorpresivo como categórico, al decirnos que efectivamente no hay ninguna mención de fabricación de fuentes por parte de Laidlaw, pero que los diseños de las tres fuentes de Alajuela son todos reconocibles como patrones del catálogo de George Smith \& Co, un destacado productor de hierro ornamental de Glasgow, de la época que estudiamos.

Conclusión: las tres fuentes de Alajuela no fueron fabricadas por R. Laidlaw \& Son. Son reconocibles como patrones del catálogo de George Smith and Co., y su fundición Sun Foundry. Todos los implementos de la cañería (tubos, acoples, etc.) sí fueron fabricados por R. Laidlaw. Es evidente que Moller y el Supremo Gobierno encargaron a R. Laidlaw todo el paquete de la cañería, incluyendo las tres fuentes. En consecuencia, esta firma, casi con toda seguridad, subcontrató las fuentes a George Smith, una de las mejores fundiciones de hierro ornamental de su época (Orozco, 2015, p. 7). Como evidencia del análisis, Scottish Ironwork Foundation

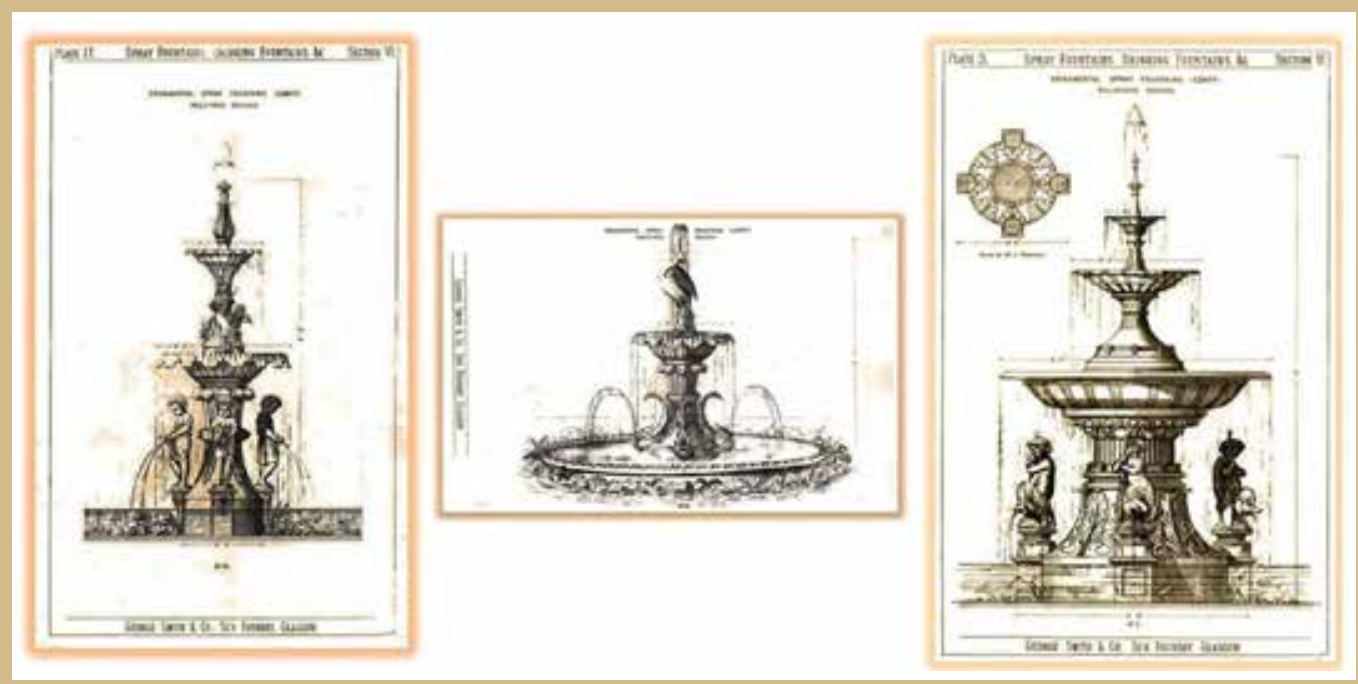


adjuntó al estudio imágenes de los tres diseños del catálogo de George Smith, en cuyos patrones se destacan, los tres, como diseños registrados de George Smith \& Co, Sun Foundry, Glasgow.

Esta empresa fue fundada en 1858, por George Smith en Port Dundas. Para 1863, ya poseía oficinas en Londres y Dublín. En los años siguientes se expandiría con oficinas en Newcastle, Liverpool, Manchester y Birmingham. También conocida como Sun Foundry, la compañía rivalizaba con Walter Macfarlane \& Co y McDowall Steven \& Co en la producción de hierro ornamental y quioscos para bandas; pero su especialidad eran los monumentos funerarios $y$, sobre todo, las fuentes ornamentales de hierro. Lamentablemente, no pudo competir al ritmo vertiginoso de aquellas firmas y cesó sus operaciones en 1899 (Orozco, 2015, p. 7). La última ubicación de Sun Foundry estaba en la calle Kennedy de Glasgow; pero el viejo edificio fue destruido por un incendio, en julio de 2012.

\subsection{Las fuentes escocesas de Alajuela.}

Las tres fuentes, junto con el lote final de materiales para la cañería, arribaron a Puntarenas, el domingo 14 de marzo de 1880 , en la fragata inglesa "Herradura", de la compañía inglesa William Le Lacheur. Aquella zarpó del puerto de Londres, el 6 de diciembre del año anterior (Orozco, 2015, p. 7).

El día 4 de julio de 1880 se realizó la inauguración de la cañería, en el Parque Central, con la asistencia de don Pedro Acosta, Gobernador de Alajuela, el Secretario de Estado, Dr. Manuel Argüello, el Dr. José Ma. Castro Madriz, en representación del Presidente Tomás Guardia - quien no pudo asistir al acto por encontrarse atendiendo asuntos urgentes del Ferrocarril, en el puerto de Puntarenas-, miembros del Consejo Nacional y de la Corte Suprema, y doña María Emilia Solórzano, esposa del Presidente, como madrina de los actos.

Para 1880, en Alajuela había únicamente tres espacios públicos para reunión social, en el centro y los extremos de la Ciudad. Dichos

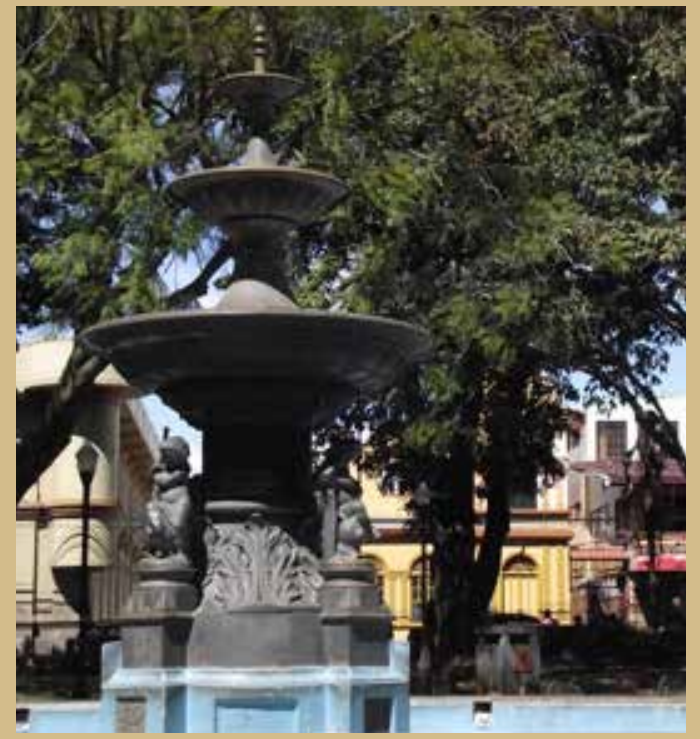

4.2. Fuente del Parque Central de Alajuela, Modelo No. 2 del catálogo de George Smith \& Co. Foto: Juan Manuel Orozco C. (2013).
4.3. Al fondo a la derecha, la fuente escocesa (modelo No. 2 de George Smith $\&$ Co.) del Parque Central de Alajuela. Al frente, un grupo de canto de Alajuela, en febrero de 1910. Foto colección de Juan Rojas Acosta. 
4.4. Fuente en el

Asilo de Ancianos Santiago Crespo Calvo (Modelo 39 de George

Smith \& (0)

Foto cortesía de Juan Rojas Acosta (2014).

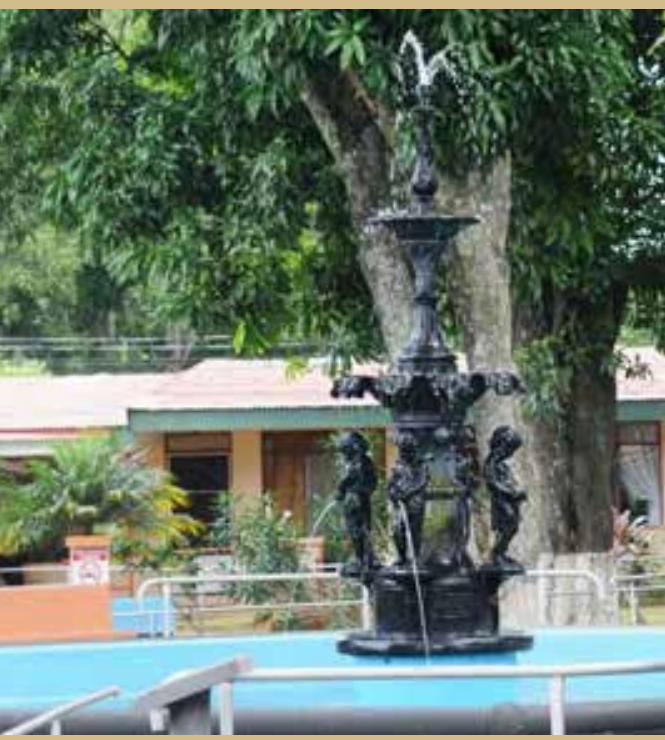

locarla en un parque de la provincia. Pero como no se disponía en ese momento de seguridad adecuada para protegerla de daños y robos, fue guardada en un plantel municipal. En 2011 la fuente regresa al Asilo y se reinaugura el $1^{\circ}$ de octubre de ese mismo año, Día del Adulto Mayor.

La tercera fuente (modelo No. 38 del catálogo de George Smith) se colocó al costado norte de la Plaza de la Iglesia La Agonía, regentada por Misioneros Reden-

4.5. Procesión al costado norte de la plaza de la iglesia La Agonía, año 1960. A centro, la fuente de San Gerardo (Modelo 38 de George Smith $\&$ Co). Foto de José Alberto Rivera Masís, cortesía de Ronald Castro Fernández.

emplazamientos fueron seleccionados estratégicamente para la ubicación de las fuentes. La más grande (modelo No. 2 del catálogo de George Smith) se colocó en el Parque Central, bautizado con el nombre Parque General Guardia.

Se colocó otra fuente más pequeña (modelo No. 39 del catálogo de George Smith) en la plazoleta del Cementerio, sitio que en 1884 sería bautizado como Parque del General Fernández. Posteriormente, esta fuente fue llevada al Hogar de Ancianos Santiago Crespo, en barrio Brasil, y allí estuvo por varias décadas hasta que, en la Administración Calderón Fournier (1990-1994), la Municipalidad la solicita de nuevo, para restaurarla y posteriormente co-

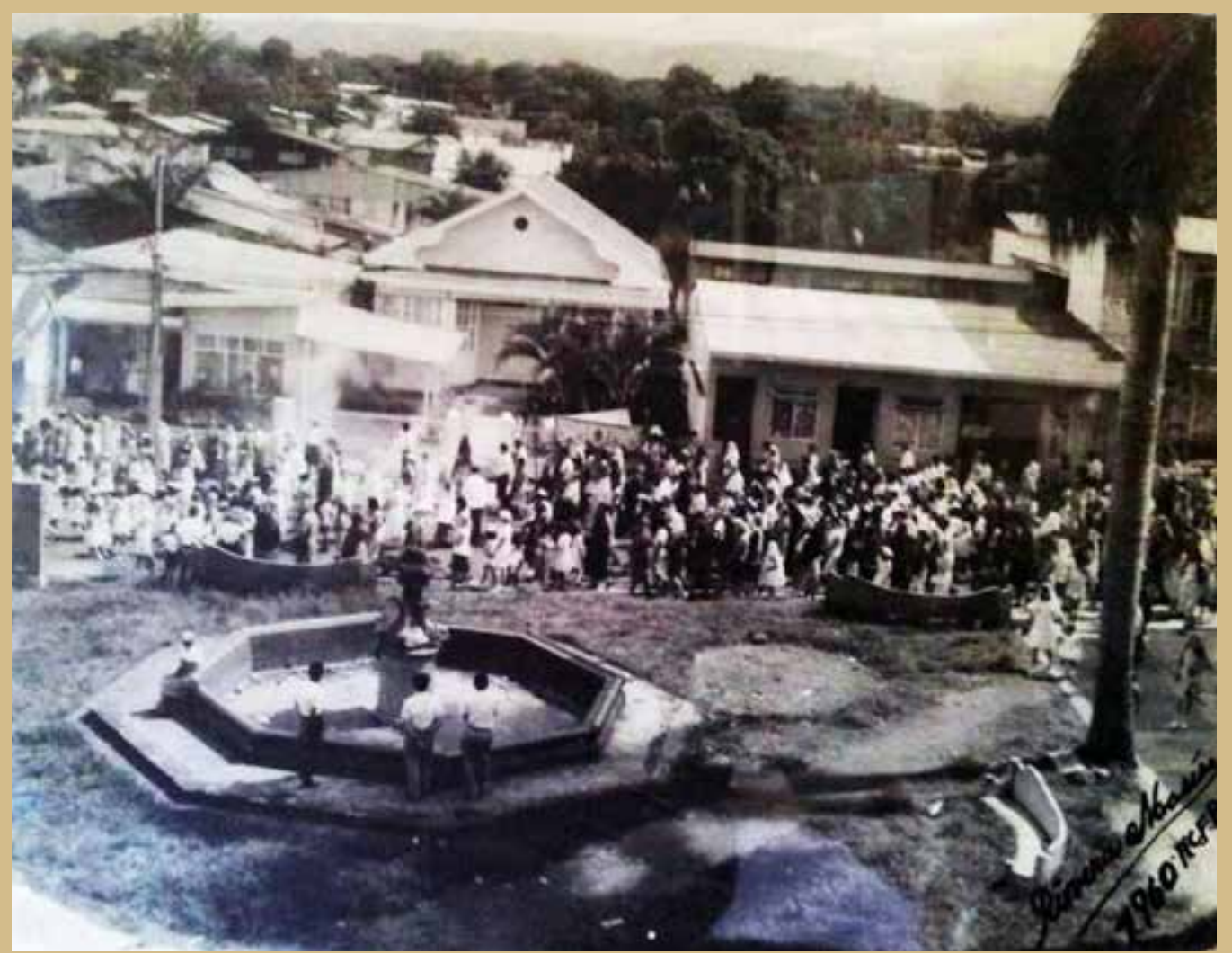


toristas. Durante muchos años, la fuente tuvo una placa que rezaba "Fuente de San Gerardo" en honor al misionero San Gerardo Mayela, santo de los Redentoristas. Luego la fuente fue retirada de su sitio y no se volvió a ver hasta hace muy poco tiem-

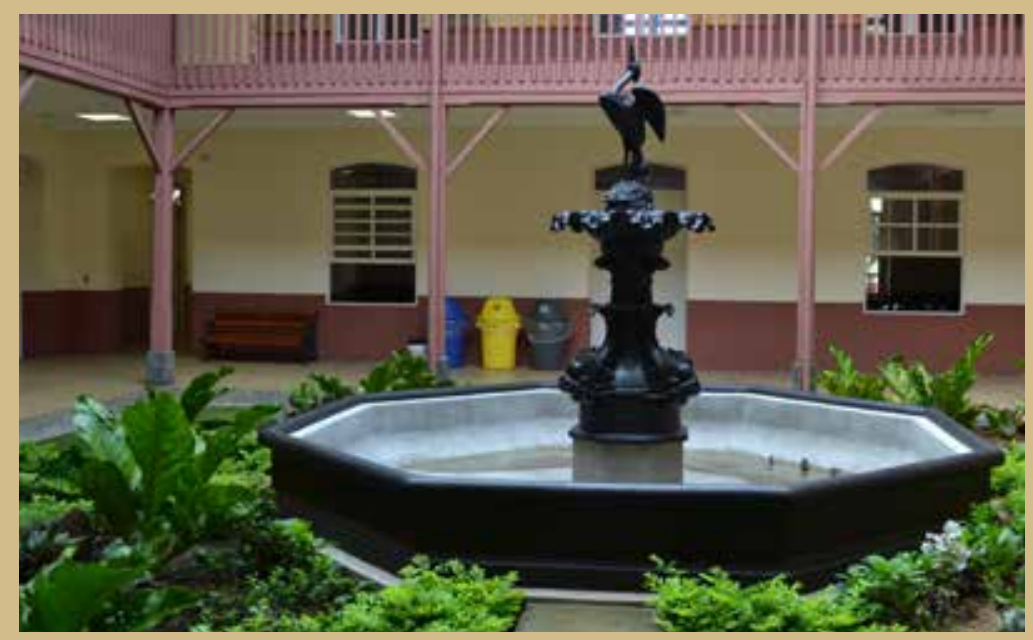
po, cuando fue restaurada. Actualmente, esta fuente se encuentra en la sede de la Universidad Técnica Nacional, costado sur del Parque de Alajuela.

Es justo reconocer que las tres fuentes se encuentran en buenas condiciones, pues fueron restauradas en años recientes, gracias a la oportuna intervención de la Municipalidad de Alajuela y al trabajo profesional de la restauradora Ana Moraleda..

\subsection{Otros ejemplares en el mundo.}

Del modelo No. 2 de George Smith, solo se conocen, a la fecha, cinco ejemplares en el mundo: dos (gemelas) en el Parque Popular de Dun Laoghaire, ciudad y puerto de la República de Irlanda, al sur de Dublín; una en Fochabers, pequeña villa de Moray, Escocia; una en el Mercado Central de Jersey (Islas del Canal, Corona Británica), y la costarricense, ubicada en el Parque Central de Alajuela.

Del modelo No. 39 del catálogo de George Smith, únicamente se conoce la existencia de otra copia, ubicada en Casa Devon, de Kingston, Jamaica. Esta casa fue construida en 1881 por George Stiebel, quien se convirtió en el primer millonario

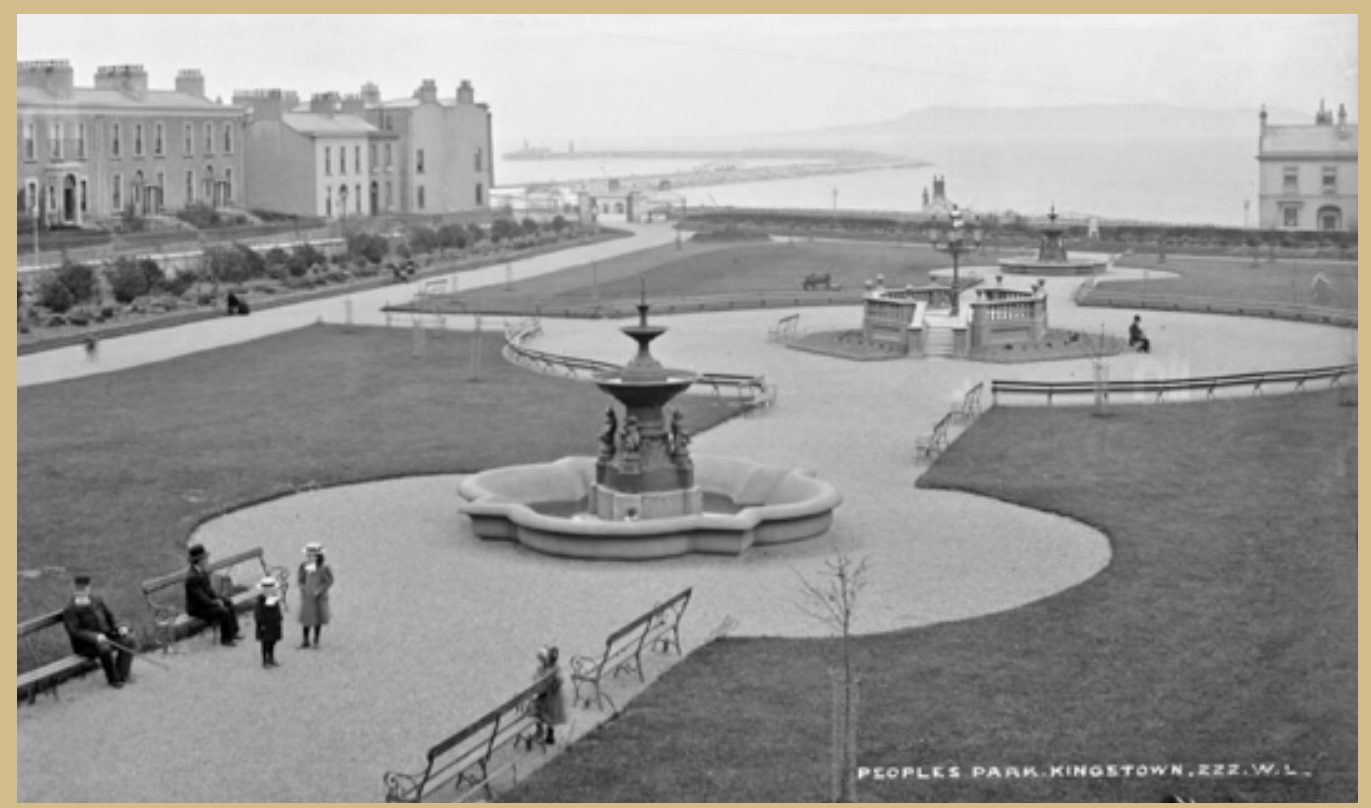

4.6. Fuente de San Gerardo, en la Universidad Técnica Nacional, costado sur del parque de Alajuela. Foto: Sergio Orozco Abarca (2015).
4.7. Fuentes gemelas en los extremos del Parque del Pueblo, Dun Laoghaire, República de Irlanda. Corresponden al modelo No.2 de George Smith \& Co. Foto de Robert French, entre 1865-1914. Imagen cortesía de la Biblioteca Nacional de Irlanda. 

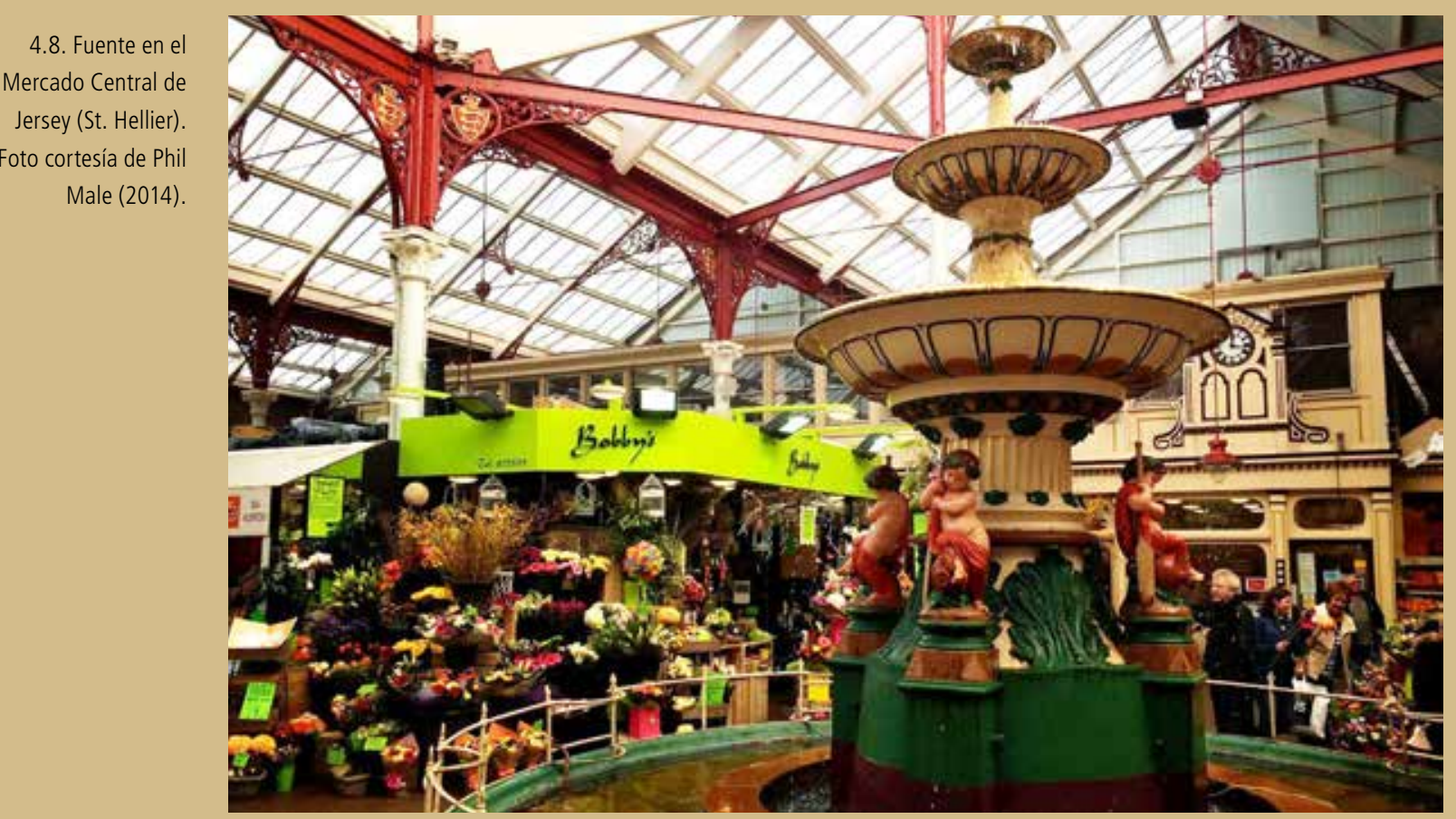

negro de Jamaica, después de ganar inmensa fortuna en la extracción de oro. El lugar abarca 4,5 hectáreas y es considerado uno de los monumentos culturales más valiosos de Kingston.

Un dato curioso es que el último dueño de la casa Devon, antes de ser convertida en monumento cultural, fue el señor Cecil Vernor Lindo, nacido en Inglaterra, pero de nacionalidad jamaiquina. Él vino a Costa Rica en la etapa de construcción del ferrocarril, donde abrió un lucrativo comercio de bienes para los trabajadores ferroviarios; luego realizó inversiones en la industria bananera, y estableció un emporio agroindustrial en Siquirres y Juan Viñas. Se casó en segundas nupcias con doña Caridad Quesada López. Fue socio fundador de la Florida Ice \& Farm Co., más conocida hoy como Cervecería Costa Rica. Murió en Kingston, de un ataque cardíaco, en el año de 1960, a la edad de 89 años. La escuela central de Juan Viñas (cantón de Jiménez, Cartago), lleva su nombre.

Del Modelo No. 38 (como la fuente de San Gerardo), por el momento, no se conocen otras copias en el mundo.

\section{[5] Otras fuentes de Costa Rica.}

"En algunas plazas públicas hay fuentes construidas con gusto, adorno también empleado con toda propiedad en los edificios públicos y casas particulares."

Apuntamientos Geográficos, Estadísticos e Históricos, compilados y arreglados por Joaquín Bernardo Calvo (1887).

Aunque las fuentes más conocidas son las de las provincias centrales, en realidad, en Costa Rica se importaron decenas de fuentes victorianas, y también se construyeron fuentes de mármol, de piedra y de otros materiales. No todas se conservan. Muchas desaparecieron. De algunas, apenas tenemos una referencia en algún documento, pero ninguna o escasísimas pruebas físicas. De otras, nos quedan únicamente sus fotos. He aquí algunos ejemplos, entre fuentes existentes y desaparecidas. 


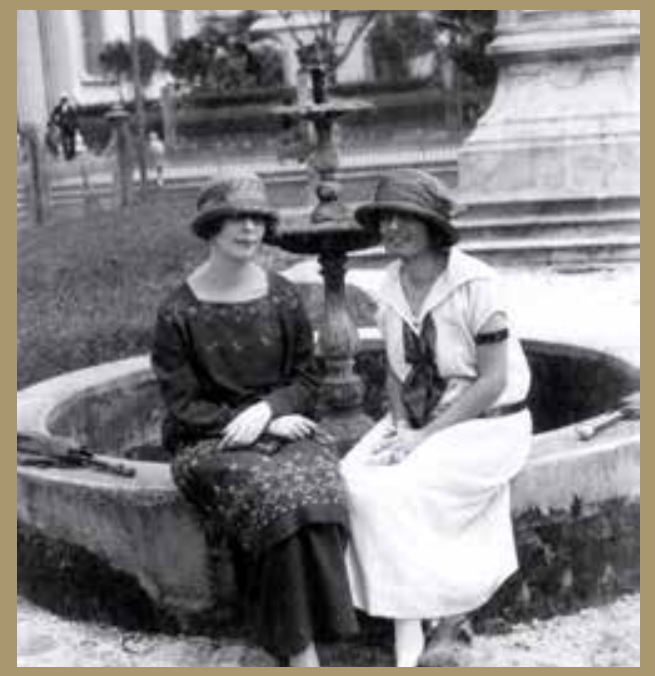

5.1. Fuente en el jardín de la Catedral Metropolitana, de San José. Fuente desaparecida. A la izquierda, doña Mercedes Campubrí; a la derecha, doña Luisa González Feo (luego, de Sáenz), pintora costarricense. Foto Manuel Gómez Miralles, 1924. Cortesía de Carmen Odio González.

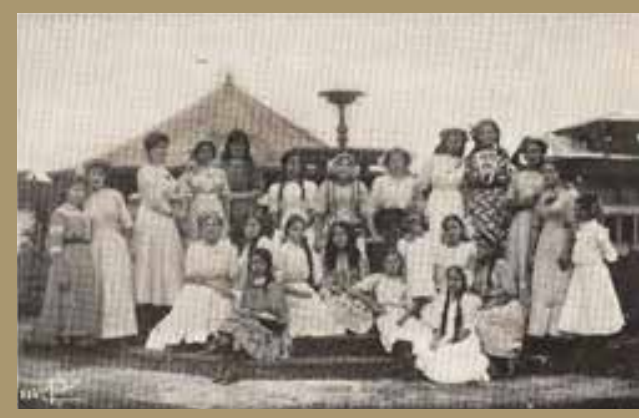

5.3. Fuente de San Ramón, imagen tomada de Páginas Ilustradas No 305, Año VIII, 15 de octubre de 1911, p. 19. La fotografía es de Manuel Gómez Miralles. En la Sede de Occidente de la Universidad de Costa Rica, se conservan el fuste y taza superiores de esta fuente.

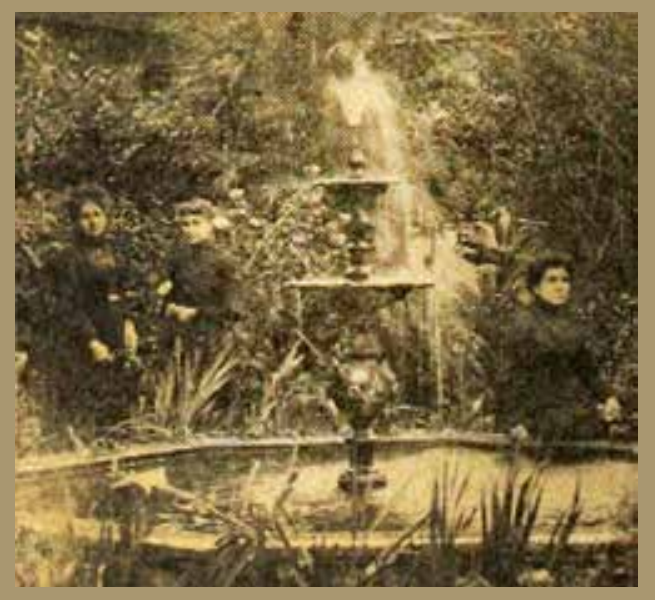

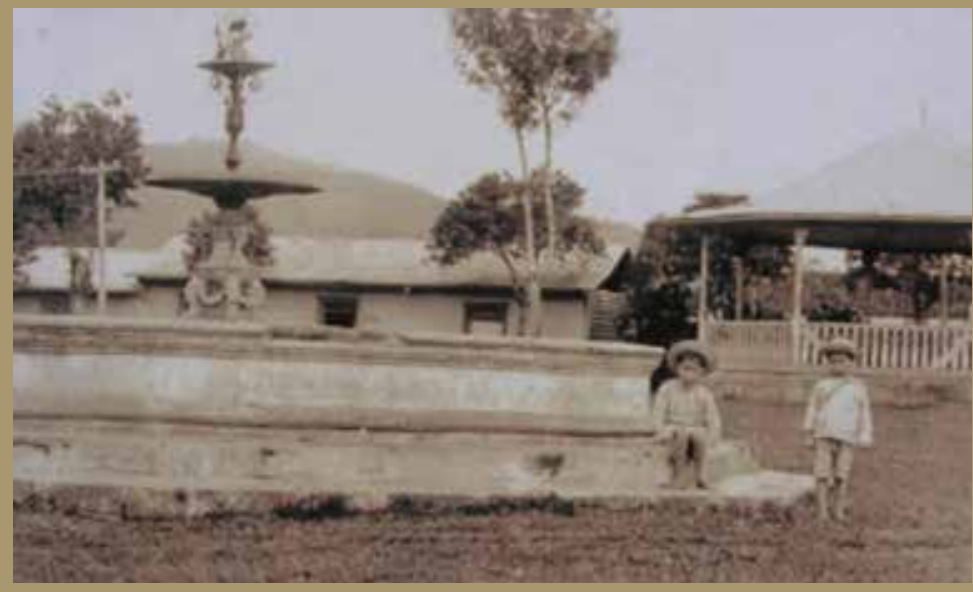

5.2. Fuente de Naranjo, en la década de 1920. Desaparecida. Foto de autor desconocido, facilitada por la página Naranjeños en Línea, de Facebook.

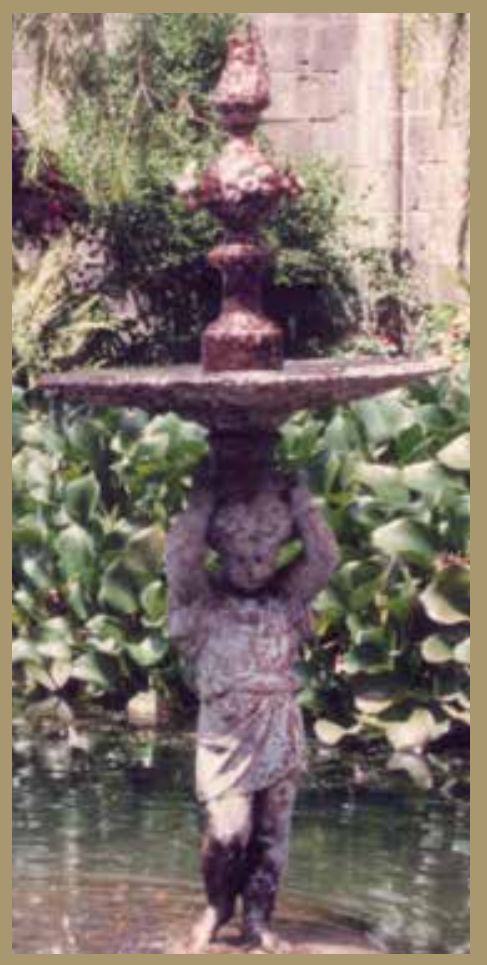

5.4. Fuente del Pastorcillo de "Las Ruinas" de Cartago. Proviene de la fundición francesa Val d'Osne. Fue quitada en a inicios de la década de los 90, cuando "Las Ruinas" fueron clausuradas. Guardada hoy (en mala condición), en unas bodegas municipales. Foto: Eduardo Castillo (circa 1990).

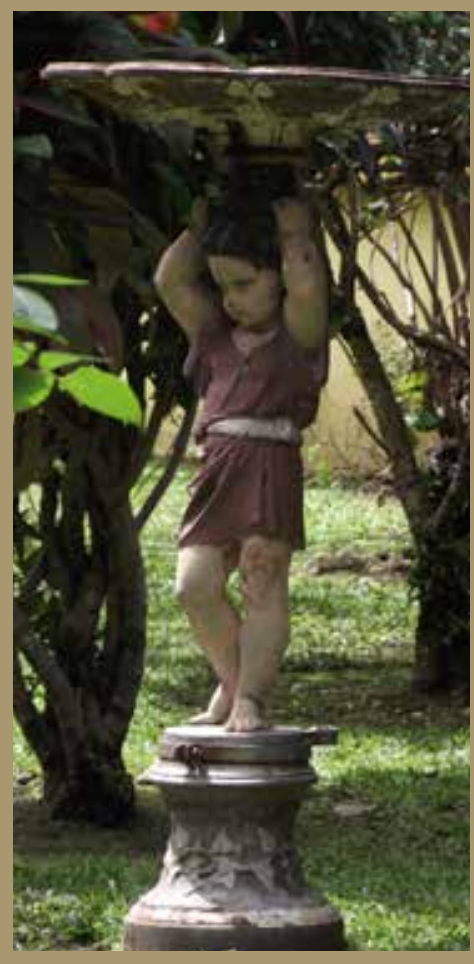

5.5. Fuente del Pastorcillo del Colegio Seminario. Proviene de la fundición francesa Val d'Osne. Actualmente se encuentra en un patio interno del Colegio Seminario en Bo. Naciones Unidas. Foto: Sergio Orozco Abarca (2013).
5.6. Fuente de la casa de la familia Espinach, en Cartago. A la izquierda, las hermanas Mercedes y Teodora Espinach; a la derecha, doña Chepita Mestre. Tomada de Mario Sancho Jiménez, "Las Casas Solariegas del antiguo Cartago", en Repertorio americano, Vol. 26, No 2, 1933, p 30. Modificada por Sergio Orozco Abarca. 


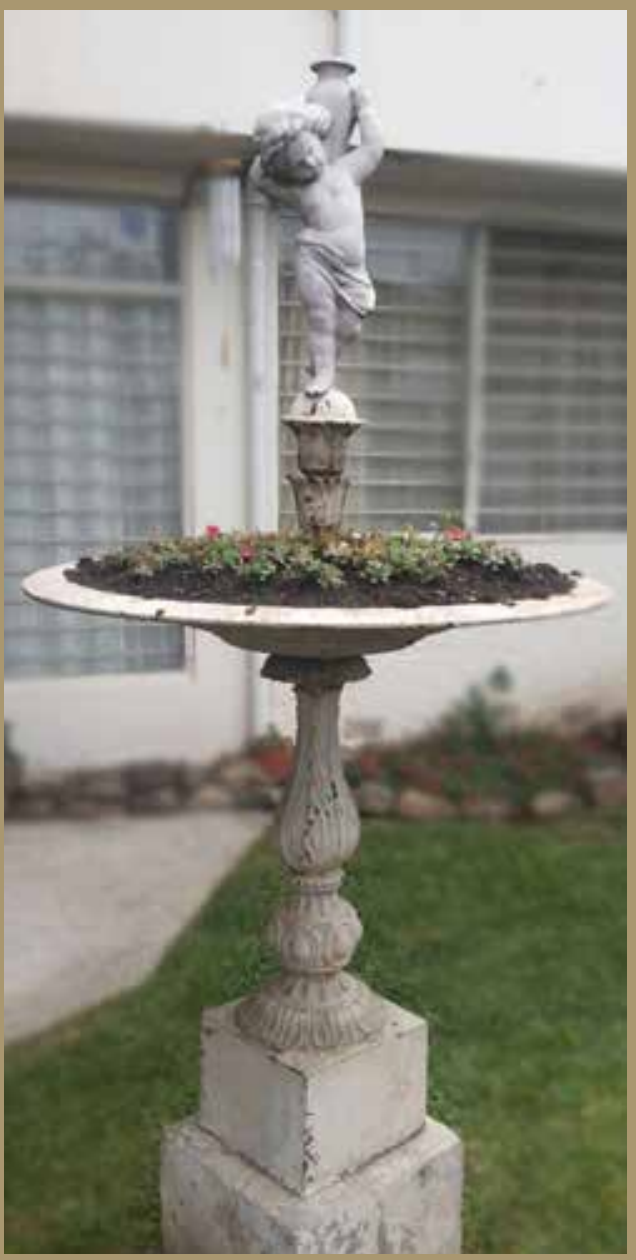

5.7. Fuente "González-Pinto", en San José, propiedad de Mercedes González Kreysa. Perteneció a don Enrique Pinto Fernández y al pintor Manuel de la Cruz González. Fabricada en Inglaterra por Andrew Handyside \& Co. Modelo No. 30.

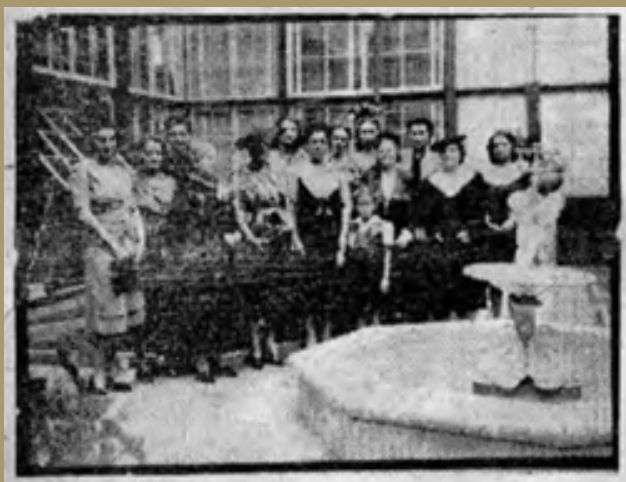

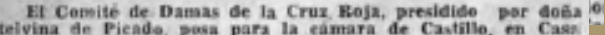

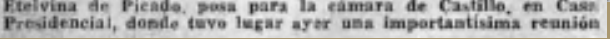

5.11. Fuente en la antigua Casa Presidencial. Tomada del diario "La Tribuna", 12 de octubre de 1944. p. 2.

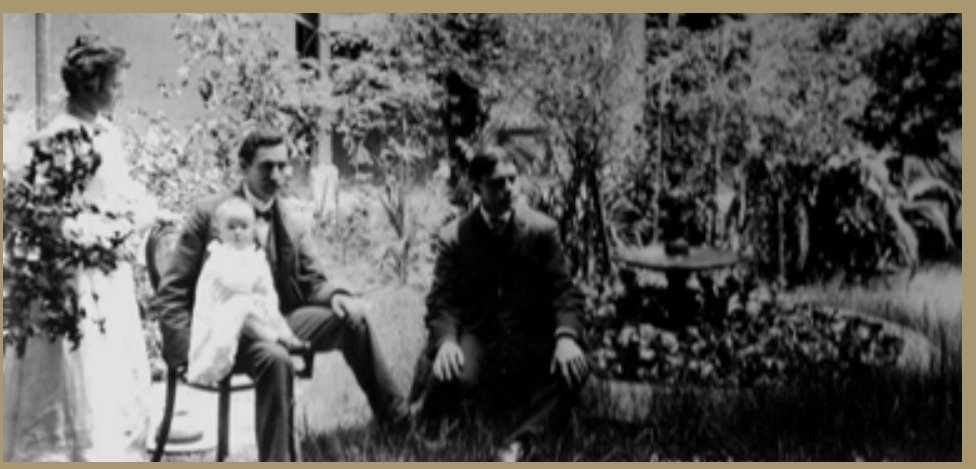

5.8. Fuente de la casa de la familia Pirie, de Cartago. Foto Nathaniel Harrison Rudd. Colección Fraser Pirie Robson.

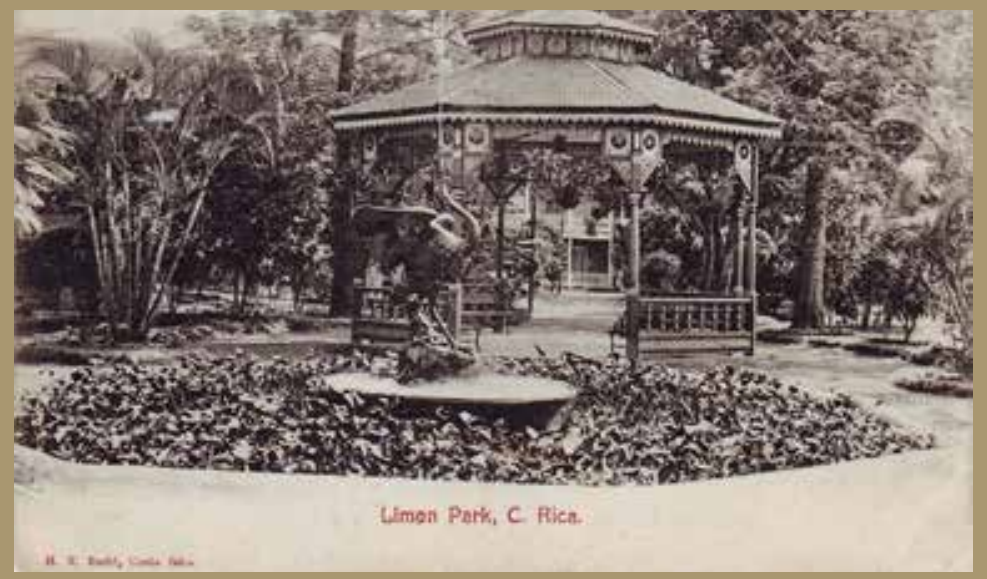

5.9. Fuente del Parque Balvanero Vargas, de Puerto Limón. Desaparecida. Foto de N. Rudd, $\sin$ fecha.

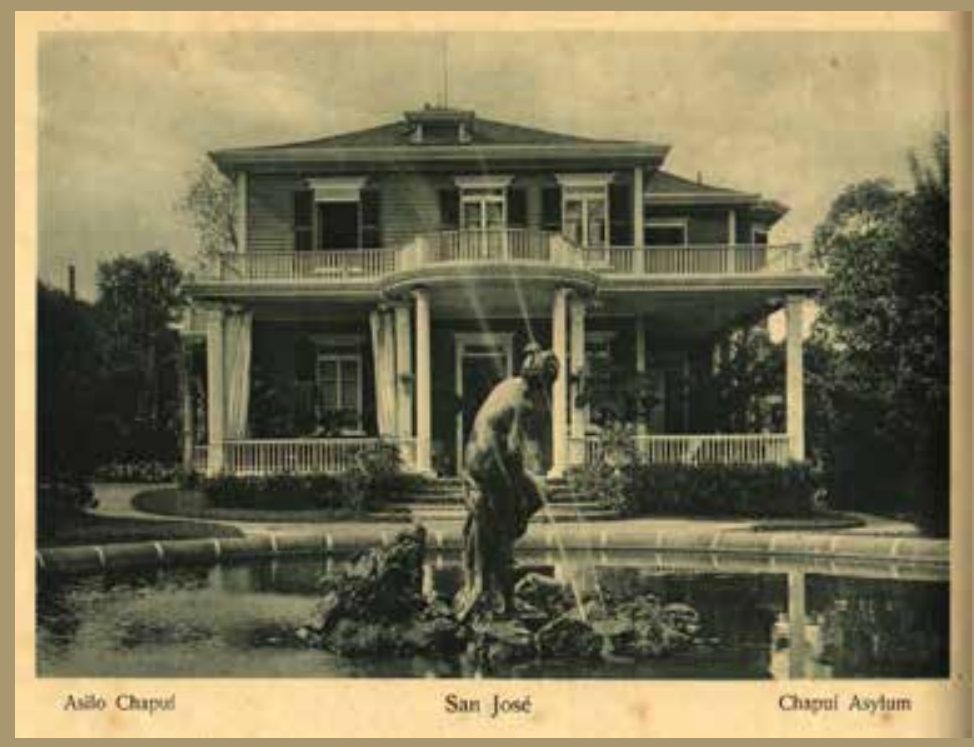

5.10. El Baño de Venus, atribuida a la fundición francesa Val d'Osne; escultura de Christophe Gabriel Allegrain (1710-1795). Esta fuente se ubicó frente a la casa del director del Asilo Chapuí. Desaparecida. Foto: Manuel Gómez Miralles, hacia el año 1922. 


\section{Fuentes primarias.}

Actas del Consejo Universitario de la Universidad de Costa Rica (1989). Sesión No.3544, ordinaria, 28 de febrero de 1989.

Actas del Consejo Universitario de la Universidad de Costa Rica (1989). Sesión No.3816, ordinaria, 18 de febrero de 1992.

Archivo Nacional de Costa Rica. Actas Municipales de Cartago, 1872-1873, Exp. 17642.

Archivo Nacional de Costa Rica. Actas Municipales de Cartago (1889).

Archivo Nacional de Costa Rica. Actas Municipales de Cartago (1892).

Archivo Nacional de Costa Rica. Archivo Nacional de Costa Rica. (1870). Hacienda 20212. (85).

\section{Periódicos.}

Diario de Costa Rica. (19 de agosto de 1897). p. 2.

El Cartaginés. (20 de noviembre de 1904). p. 2.

La Gaceta. (9 de septiembre de 1872). Año 12, semestre 2o. Núm. 35, p. 3.

La Gaceta. (11 de diciembre de 1869) p. 5.

\section{Pácínas en Internet.}

Adelaide In Photos: (http://adelaide-in-photos.blogspot.com/)

CR Trenes: (http://crtrenes.blogspot.com)

Eduardo Sánchez: (http://soloheredia.blogspot.com)

Glasgow West-end Addresses and their Occupants 1836-1915: (http://www.glasgowwestaddress.co.uk/)

Página de Facebook: "Heredia Ciudad Eterna": (https://www.facebook.com/ herediafotos/?fref=ts)

Jim Scott: (www.jimscott.co.uk)

Lima Turística: (http://www.limaturistica.com/)

Un día de Mercado en la Cartago Colonial: (http://www.micartago.com/index. php?news=3953)

Lucía Juárez: (http://www.luciajuarez.com)

Página de Facebook: "Naranjeños en Línea": (https://www.facebook.com/Naranjenos. en.linea/?fref=ts)

Nelson Mangalama: (htttp://discover-srilanka.blogspot.com)

Purcell Architects: (http://www.purcelluk.com/)

\section{Bibliografía.}

Biblia Latinoamericana. (s.f.). Salmos. Recuperado el 2015, de http://www.sobicain.org/ shell.asp?p=Biblia

Brenes, Guillermo. (2012) Reminiscencias de la muy noble y leal ciudad de Cartago. Trabajo Inédito.

Brenes, Guillermo. (2010). "Un día de mercado en la Cartago Colonial". Recuperado en 2015 de: http://www.micartago.com/index.php?news=3953.

Calvo, Joaquín B. (1887) Apuntamientos Geográficos, estadísticos e históricos (1886). San José: Imprenta Nacional.

Cáceres, José (1880). Geografía de Centro América. París: Librería de Garnier Hermanos.

Castillo, Eduardo. (1977). Plaza Mayor de Cartago ¿Por qué? ¿Para qué? ¿ De quién? Recuperado el 2015, de : https://www.facebook.com/notes/eduardo-alfonsocastillo-rojas/plaza-mayor-de-cartago-por-qu\%C3\%A9-para-qu\%C3\%A9-dequi\%C3\%A9n/264382216913089?_mref=message

Coto, Rogelio. (1987) Cuando el fútbol llegó a Cartago. San José: Publicaciones Coto y Aguilar.

De la Goublaye de Menorval, Yves. (2010). "Familias de origen croata en Costa Rica, 
Familia Orlich". En: Boletín electrónico de la Academia Costarricense de Ciencias Genealógicas, No. 93, p. 17.

Delgado, Jorge M. (s. f.) La fuente peregrina. Documento inédito.

Gómez, Sonia. (2007) La basílica de Nuestra Señora de los Ángeles: Testimonio arquitectónico de la fe costarricense. San José: Ministerio de Cultura y Juventud, Centro de Investigación y Conservación del Patrimonio Cultural. Imprenta Nacional.

Handyside \& Company. (1879). An Illustrated Book Of Designs For Fountains and Vases, Costing From f1 to $f 1200$ manufactured by Andrew Handyside.

Hopwood, Rosalind (2009). Fountains and water features, from ancient springs to modern marvels. Inglaterra: Frances Lincoln, Limited.

Cáceres, José María. (1891) Geografía de Centro-América. Paris Garnier frères libraireséditeurs.

Mata, Jesús. (1999) Monografía de Cartago. Cartago: Editorial Tecnológica de Costa Rica.

Mata, Jesús (1970) "El cambio de siglo". En: Historias de Cartago. San José: Imprenta Moderna.

Matheson, Ewing (1877) Works in iron: Bridge and roof structures. London: E. \& F. N. Spon.

Meléndez, Carlos. (2001) Añoranzas de Heredia. Heredia: Universidad Nacional.

Montero B., Francisco. (1892) Geografía de Costa Rica. Barcelona: Tip. Lit. de José Cunill Sala. P. 189.

Morgan, Henry (1989) Vistas de Costa Rica. San José: Comisión del Centenario de la democracia costarricense 1889-1989. Imprenta Nacional.

Núñez, Francisco (1944). "Con fondos del ministro Francisco María Iglesias se construyó el parque Central de San José". En: Diario de Costa Rica, 9 de enero, p. 1

Núñez, Francisco (2004) "En 1868 se inauguró la primera cañería subterránea de San José". En: Zeledón, Elías (ed.) Del viejo San José. San José: Editorial de la Universidad de Costa Rica: pp. 53-56.

Núñez, Francisco (1958). "Inaguración de la primera cañería subterránea de San José". En: La República. 22 de diciembre, pág. 43.

Orozco Abarca, Sergio (2015). "El inesperado origen de las fuentes de Alajuela". En: suplemento "Áncora", de La Nación, domingo 2 de agosto, 2015.

Payne, Ma. Elizet (1986). "Actividades artesanales. Siglo XVII (Maestros, oficiales y aprendices)". En: Costa Rica colonial. San José: Publicación de la Comisión costarricense V Centenario del Descubrimiento de América"

Powell, John. (2013). The Boy and Swan Notes. Documento inédito.

Raistrick, Arthur (1970) Dynasty of iron founders: The Darbys and Coalbrookdale. Devon, England: David \& Charles (Publishers) Limited.

Segura, Pompilio y Sanchez, Eduardo (2012). Historia del alumbrado y la cañería de Heredia. Documento inédito.

Sancho, Mario (1933). "Las Fontanas de Cartago". En: Repertorio americano, Vol. XXVI, No. 7, p. 100.

Sancho, Mario (1961). Memorias. San José: Editorial Costa Rica.

Sanou, Ofelia. (2001). Arquitectura e historia en Costa Rica, templos parroquiales en el Valle Central, Grecia, San Ramón y Palmares. San José, Costa Rica : Editorial Universidad de Costa Rica.

The Royal Commission. (1851). Official Descriptive and Illustrated Catalogue of Great Exhibition of the Works of Industry of all Nations. Londres, Inglaterra: Spicer brothers.

Vargas Sanabria, Asdrúbal. (2001). "El manejo histórico de los recursos hídricos en Costa Rica con énfasis en el período indígena y en los siglos XVI, XVII, XVIII y XIX". En Anuario de Estudios Centroamericanos, Universidad de Costa Rica. Vol 27, No. 1: p. 59-81.

Vecinos (1991). Periódico mensual. San Pedro de Montes de Oca. Abril de 1991. p. 2. 